TATIANA FACCHIM

\title{
A SOCIEDADE UNIPESSOAL COMO FORMA ORGANIZATIVA DA MICRO E PEQUENA EMPRESA
}

Dissertação apresentada à Faculdade de Direito da Universidade de São Paulo para obtenção do título de Mestre em Direito Comercial, sob orientação da Professora Doutora Vera Helena de Mello Franco

Faculdade de Direito da Universidade de São Paulo São Paulo

2010 
Aos meus pais e ao Paulo, sem os quais eu não teria chegado até aqui. 
"A regra da igualdade não consiste senão em quinhoar desigualmente aos desiguais, na medida em que se desigualam. Nesta desigualdade social, proporcionada à desigualdade natural, é que se acha a verdadeira lei da igualdade. $O$ mais são desvarios da inveja, do orgulho, ou da loucura. Tratar com desigualdade a iguais, ou a desiguais com igualdade, seria desigualdade flagrante, e não igualdade real. Os apetites humanos conceberam inverter a norma universal da criação, pretendendo, não dar a cada um, na razão do que vale, mas atribuir o mesmo a todos, como se todos se equivalessem"

Rui Barbosa - Oração aos Moços (1920) 


\section{RESUMO}

O trabalho tem por objetivo abordar a adoção da sociedade unipessoal como forma organizativa da micro e pequena empresa, demonstrando não só a viabilidade jurídica de sua inserção no ordenamento brasileiro como também a conveniência de seu estabelecimento como uma das alternativas de organização do empresário singular.

Palavras chave: sociedade unipessoal; empresário individual; micro e pequena empresa. 


\section{ABSTRACT}

The essay deals with the subject of the acceptance of the one-man partnership as an alternative for structuring micro and small companies in Brazil, evidencing not only that it is possible to insert this kind of partnership within the Brazilian legal system, but also the convenience of adopting such option for the organization of the sole entrepreneur.

Keywords: one-man partnership; sole entrepreneur; micro and small companies. 


\section{SUMÁRIO}

INTRODUÇÃO.

1. A RELEVÂNCIA DAS MICRO E PEQUENAS EMPRESAS ................. 4

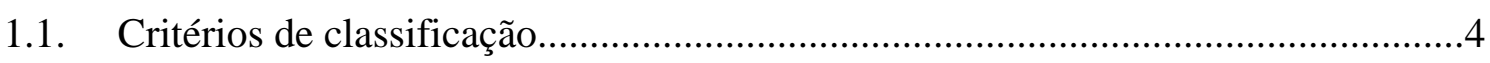

1.2. Participação em âmbito nacional ..................................................................

1.3. Participação no Estado de São Paulo ................................................................. 8

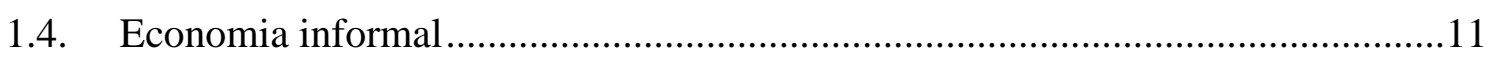

2. PESSOA JURÍDICA: EVOLUÇÃO DO CONCEITO............................. 13

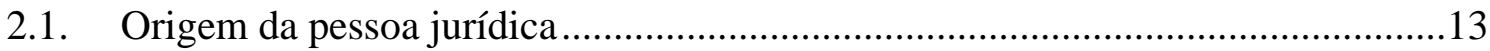

2.2. Evolução dos conceitos de personificação e limitação patrimonial .......................17

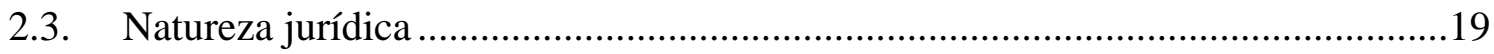

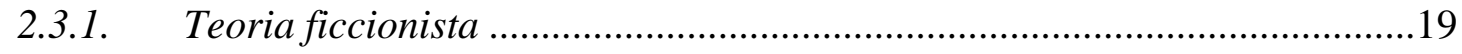

2.3.2. Pessoa jurídica como realidade objetiva ....................................................21

2.3.3. Pessoa jurídica como realidade técnica ....................................................22

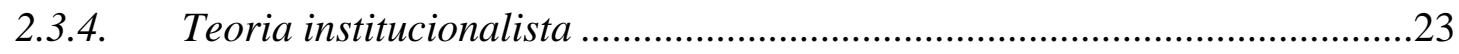

2.4. O conceito de pessoa jurídica no ordenamento brasileiro..................................24

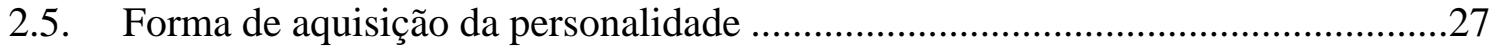

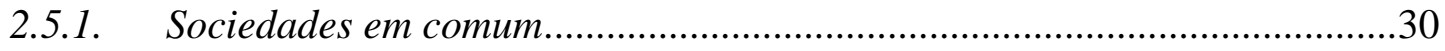

2.5.2. Sociedades em conta de participação ............................................................

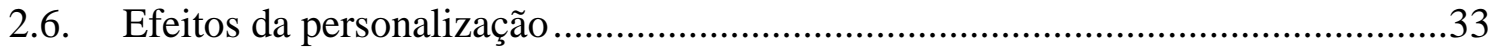

3. A PROBLEMÁTICA DA LIMITAÇÃO DE RESPONSABILIDADE DO

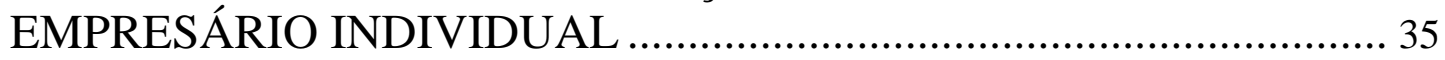

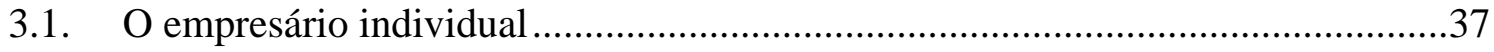

3.2. Origem do preconceito relativo à limitação de responsabilidade do empresário

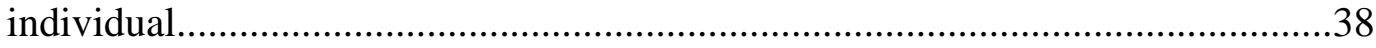

3.3. As sociedades fictícias como forma de limitação de responsabilidade..................40

3.3.1. Simulação e negócio indireto ......................................................................... 40

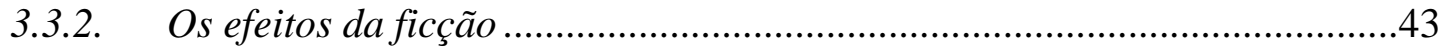

4. A FORMA NÃO SOCIETÁRIA DE ORGANIZAÇÃO DA LIMITAÇÃO: SEPARAÇÃO PATRIMONIAL ............................... 47

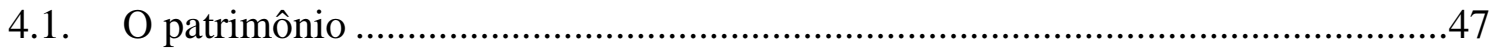

4.2. Tentativas de construção da forma não societária................................................52

4.3. Crítica à limitação de responsabilidade pela via do patrimônio de afetação .........57 


\section{O RECONHECIMENTO DA SOCIEDADE COM UM SÓ SÓCIO....... 61}

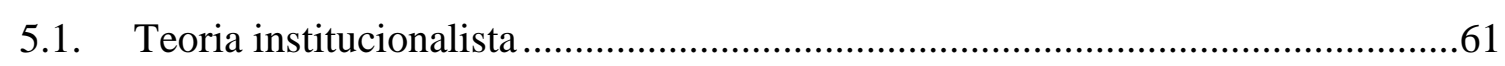

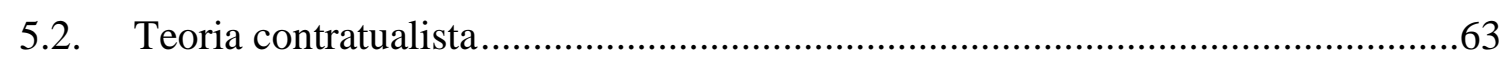

5.3. Do contrato plurilateral ao contrato-organização.............................................64

5.4. A superioridade da forma societária sobre a técnica do patrimônio de afetação..68

6. A SOCIEDADE UNIPESSOAL NO DIREITO COMPARADO .......... 70

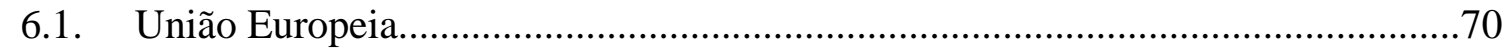

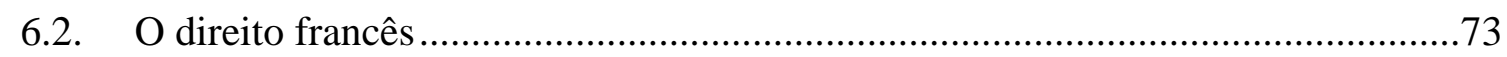

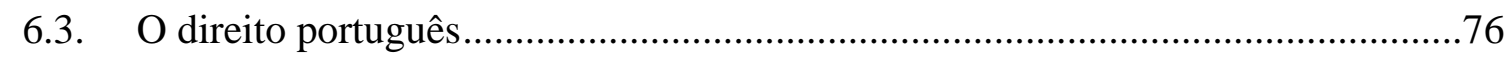

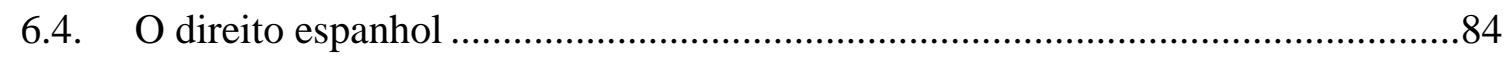

7. A POSIÇÃO NO BRASIL ..................................................... 88

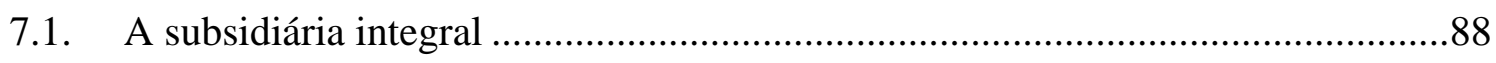

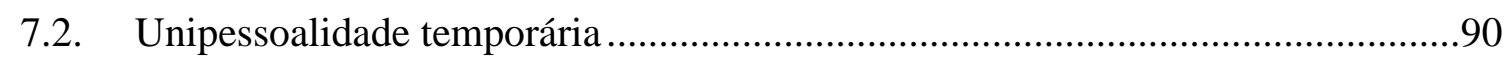

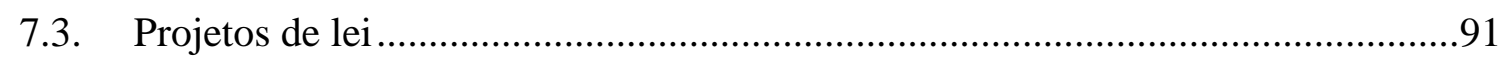

7.3.1. $\quad$ Anteprojeto de Lei de Sociedades de Responsabilidade Limitada................91

7.3.2. Projetos posteriores ao CC 2002 ..............................................................92

8. ESTRUTURA ORGANIZATIVA DA SOCIEDADE UNIPESSOAL...103

8.1. Tipos societários adequados à micro e pequena empresa ...................................103

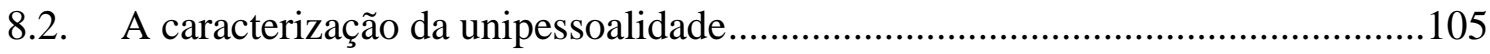

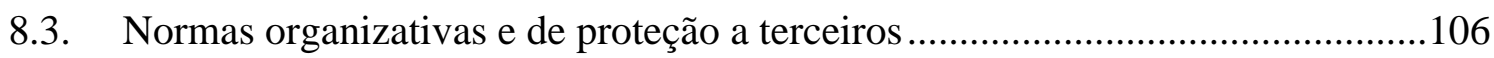

8.3.1. Constituição e normas aplicáveis …..........................................................107

8.3.2. Publicidade das informações ......................................................................107

8.3.3. Garantias do capital social .........................................................................109

8.3.4. Negócios entre sócio e sociedade ………...................................................111

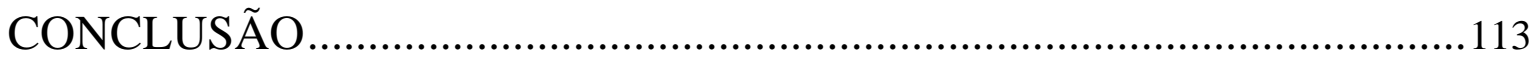

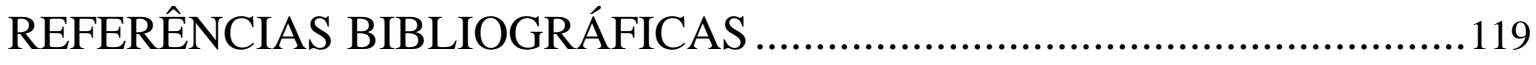




\section{INTRODUÇÃO}

O presente trabalho tem por objetivo abordar a adoção da sociedade unipessoal como forma organizativa da micro e pequena empresa, demonstrando não só a viabilidade jurídica de sua inserção no ordenamento brasileiro como também a conveniência de seu estabelecimento como uma das alternativas de organização do empresário singular.

Por seus claros benefícios no que tange tanto às opções atualmente existentes - quais sejam a figura do empresário individual e a sociedade com sócio "de favor" - como à solução não societária da separação patrimonial, como se procurará demonstrar, a sociedade unipessoal é o tipo ideal para o desenvolvimento de negócios por aqueles indivíduos que, pelos mais diversos motivos, desejam explorar a atividade empresária de forma singular.

No primeiro capítulo, demonstra-se a relevância socioeconômica das micro e pequenas empresas, ressaltando a diversidade de critérios de classificação e sua participação substancial nos mercados. Faz-se, também, uma breve digressão sobre a informalização, fruto principalmente da burocracia e da elevada carga tributária.

Um dos grandes benefícios da sociedade unipessoal é a possibilidade de personificação da empresa, a criação de um centro autônomo de imputação de direitos e deveres, independente da figura dos sócios. Por isso, o segundo capítulo aborda o conceito e a evolução da pessoa jurídica, de forma abreviada, dada a extraordinária complexidade do tema. Assim, tratar-se-á da origem da pessoa moral e da evolução do conceito de personificação (e da intrinsecamente conexa limitação de responsabilidade), incluindo seu desenvolvimento no ordenamento pátrio, passando pela natureza jurídica do instituto e as diferentes teorias que dela cuidaram, para chegar às formas de aquisição da personalidade jurídica e efeitos da personificação.

O terceiro capítulo é dedicado à análise da questão da limitação da responsabilidade relativamente àqueles que exercem a empresa de forma individual. Para tanto, faz-se um estudo da situação do empresário individual na legislação brasileira e da origem do preconceito relativo à limitação de responsabilidade deste. Na sequência, o trabalho traz uma visão crítica da criação de sociedades fictícias, ou de favor, em que o empresário individual se vale do auxílio e concordância de outras pessoas para constituir, 
assim, sociedade pluripessoal e aproveitar-se dos benefícios da responsabilidade limitada no exercício de suas atividades.

Uma vez exposto o problema, passa-se a discorrer sobre as possíveis soluções. Desse modo, no quarto capítulo há uma análise da forma não societária de limitação de responsabilidade do empresário individual, pela via da separação patrimonial. Após tratar da superação da teoria da unidade do patrimônio e da possível existência de patrimônios especiais e separados, são analisadas as posições dos defensores da teoria no Brasil, com destaque para Sylvio Marcondes Machado e sua clássica obra de 1956.

Nada obstante o brilhantismo do mencionado autor e dos demais defensores da limitação de responsabilidade pela separação patrimonial, quiçá enviesados pelos preconceitos ainda existentes à época, a solução merece críticas por seus inúmeros inconvenientes, como a dificuldade de transmissão da empresa a terceiros, a impossibilidade de ampliação do negócio e de obtenção de crédito descolado da figura do empresário e a dificuldade em manter a separação patrimonial e a necessária distinção entre o empresário e o estabelecimento, que são então, um a cada vez, abordados.

O quinto capítulo se dedica à comprovação da inexistência de óbices teóricos ao reconhecimento da sociedade unipessoal pela superação do conceito de que a forma associativa apenas se justifica como uma maneira de unificar a pluralidade de sócios a ela subjacente. Para tanto, procede-se ao estudo da evolução do conceito de sociedade, passando-se da teoria institucionalista germânica e da escola contratualista italiana à análise do contrato associativo e a teoria do contrato-organização.

Conclui-se, assim, pelo reconhecimento da sociedade com um só sócio, passando-se então ao seu estudo e à defesa da superioridade da forma societária para tanto.

O sexto capítulo cuida do estudo da evolução da sociedade unipessoal no direito comparado, ressaltando-se ter sido o instituto adotado na grande maioria dos países desenvolvidos. Pela avaliação da legislação comunitária europeia, bem como das normas francesa, portuguesa e espanhola, é possível concluir que a sociedade unipessoal perdeu seu caráter de impropriedade terminológica e passou a ser vista como uma consequência do caráter organizativo das sociedades, da estruturação de um ente dirigido à consecução de determinado objetivo. A sociedade passa a ser a organização de capital e trabalho para atender às necessidades do mercado, o que independe do simples agrupamento de pessoas. 
O sétimo capítulo trata da posição brasileira no tocante à sociedade unipessoal, fazendo-se uma brevíssima análise da subsidiária integral e da unipessoalidade temporária, hipóteses legais que indicam claramente ser possível a adoção plena do instituto no país, uma vez superadas as barreiras teóricas já há muito ultrapassadas no direito comparado. Houve e há, inclusive, uma série de projetos de lei nesse sentido, os quais são detalhados e criticados.

Finalmente, por tratar-se de sociedade com um único sócio, deve haver uma maior preocupação com relação à perfeita distinção de interesses, protegendo não só terceiros como a própria sociedade e os benefícios que ela traz à economia e à sociedade como um todo. Assim sendo, o oitavo e último capítulo é afeito ao estudo da estrutura organizativa da sociedade unipessoal e da necessária separação entre interesses sociais e interesses pessoais do sócio. Nesse ponto, são avaliados os tipos societários adequados à micro e pequena empresa, foco do presente estudo; a forma de caracterização da unipessoalidade e as normas organizativas e de proteção a terceiros, como as regras relativas à constituição e à publicidade, às garantias do capital social e aos negócios entre sócio e sociedade. 


\section{A RELEVÂNCIA DAS MICRO E PEQUENAS EMPRESAS}

Em razão da redução do crescimento da economia observada na década de 80, os pequenos negócios passaram a ser vistos como alternativa para ocupação da mão de obra excedente, em geral menos qualificada, que não encontrava colocação nas grandes empresas.

Isso levou à implantação de uma política nacional de desburocratização, com a adoção de medidas concretas para incentivar a abertura de micro e pequenas empresas $^{1}$, dentre as quais se destaca o primeiro Estatuto da Microempresa (Lei $\mathrm{n}^{\circ}$ 7.256, de 27.11.1984) e a inclusão, na Constituição Federal de 1988, da garantia de tratamento diferenciado às micro e pequenas empresas ${ }^{2}$.

A partir de então, o número de micro e pequenas empresas tem majorado de forma extraordinária e as mesmas são, hoje, imprescindíveis para a economia nacional e para a geração de emprego e renda.

É de se ressaltar que esse fenômeno não se restringe ao Brasil, mas pode ser observado, de forma mais ou menos uniforme, em âmbito global, sendo as empresas de menor porte a mais relevante forma de geração de ocupação e renda e um dos grandes motores da economia mundial.

\subsection{Critérios de classificação}

No Direito italiano houve intenso debate quanto à disciplina aplicável às pequenas empresas. Enquanto parte da doutrina defendia que a piccola impresa era qualitativamente distinta das demais - conclusão que faria desta uma nova entidade, com

\footnotetext{
${ }^{1} \mathrm{O}$ termo "empresa" tem conotação obviamente empresária, quando na realidade o que se pretende englobar são não somente as atividades tipicamente negociais, mas também aquelas inerentes às sociedades simples.

Como defende Gladston Mamede, seria mais adequado usar o termo "atividade negocial" no lugar de empresa. Cf. MAMEDE, Gladston [et. al.]. Comentários ao estatuto Nacional da Microempresa e da Empresa de Pequeno Porte: lei complementar $n^{\circ}$ 123, de 14 de dezembro de 2006. São Paulo: Atlas, 2007, p. 375.

2 Art. 179: "A União, o Estado, o Distrito Federal e os Municípios dispensarão às microempresas e às empresas de pequeno porte tratamento jurídico diferenciado, visando a incentivá-las pela simplificação de suas obrigações administrativas, tributárias, previdenciárias e creditícias, ou pela eliminação ou redução destas por meio de lei."
} 
regulamento próprio - a maioria defendia tratar-se de conceito meramente de ordem quantitativa, diferindo das grandes e médias empresas apenas pelo volume de negócios e relações jurídicas e sujeitas, portanto, ao mesmo regime, salvo derrogação ou estabelecimento de regime especial ${ }^{3}$.

Hodiernamente não há ainda unanimidade quanto ao critério de definição e classificação das micro e pequenas empresas. Diferentes regras de determinação são aplicadas pela legislação, pelos órgãos representativos do setor, pelos institutos de pesquisa e pelas instituições financeiras, sendo os critérios baseados ora em faturamento, ora no número de pessoas ocupadas, ora nas características organizacionais da empresa.

A utilização de diferentes critérios se dá em função dos distintos objetivos de cada classificação, quais sejam regulamentação (no caso do legislativo), estudos (no que diz respeito aos órgãos representativos e institutos de pesquisa) ou concessão de crédito (para as instituições financeiras).

De acordo com a classificação do Serviço de Apoio às Micro e Pequenas Empresas (SEBRAE) e do Instituto Brasileiro de Geografia e Estatística (IBGE), são consideradas microempresas aquelas que possuem até 09 empregados, no setor de comércio e serviços, e até 19 empregados no setor industrial. Já as empresas de pequeno porte são aquelas que possuem entre 10 e 49 empregados, no setor de comércio e serviços, e entre 20 e 99 empregados no setor industrial.

Com relação à classificação por número de pessoas, ressalte-se que não leva em conta as diferenças entre os processos produtivos das diferentes atividades, que podem prescindir de grande número de funcionários - como aquelas em que há uso intensivo da tecnologia ou forte presença de mão de obra qualificada.

Nos termos da Lei Complementar $n^{\circ} 123$, de 14.12.2006 (Estatuto Nacional da Microempresa e da Empresa de Pequeno Porte), são consideradas microempresas

\footnotetext{
3 PALERMO, Fernanda Kellner de Oliveira. "As micro e pequenas empresas como propulsoras do desenvolvimento econômico e social - contribuição para o incremento das atividades econômicas no âmbito do MERCOSUL”. In Revista de Direito Mercantil Industrial, Econômico e Financeiro, v. 124, 2001, p. 184.
} 
aquelas que apresentam receita bruta anual de até $\mathrm{R} \$ 240$ mil e empresas de pequeno porte aquelas com receita bruta anual entre $\mathrm{R} \$ 240$ mil e $\mathrm{R} \$ 2,4$ milhões ${ }^{4}$.

Já para o Banco Nacional de Desenvolvimento Econômico e Social (BNDES), de acordo com o critério adotado pelos países do MERCOSUL para fins creditícios, são consideradas microempresas aquelas que apresentam receita anual de até US\$ 400 mil e empresas de pequeno porte aquelas com receita anual entre US\$ 400 mil e US\$ 3,5 milhões.

Outro critério de classificação, de fins mais didáticos, seria aquele referente à estrutura da organização da microempresa e da empresa de pequeno porte, em que o proprietário centraliza quase todas as atividades ${ }^{5}$. De acordo com pesquisa efetuada pelo Instituto Brasileiro de Geografia e Estatística (IBGE), são características das micro e pequenas empresas comerciais e de serviços ${ }^{6}$ :

- baixa intensidade de capital;

- altas taxas de natalidade e de mortalidade;

- forte presença de proprietários, sócios e membros da família como mão de obra ocupada nos negócios;

- poder decisório centralizado;

- estreito vínculo entre os proprietários e as empresas, não se distinguindo, principalmente em termos contábeis e financeiros, pessoa física e jurídica;

- registros contábeis pouco adequados;

- contratação direta de mão de obra;

- utilização de mão de obra não qualificada ou semiqualificada;

\footnotetext{
${ }^{4}$ Entendida receita bruta como (i) o produto da venda de bens e serviços nas operações de conta própria e (ii) o preço dos serviços prestados e o resultado das operações em conta alheia, excluídas as operações canceladas e descontos incondicionais concedidos.

5 PALERMO, Fernanda Kellner de Oliveira. "As micro e pequenas empresas como propulsoras do desenvolvimento econômico e social - contribuição para o incremento das atividades econômicas no âmbito do MERCOSUL”. In: Revista de Direito Mercantil Industrial, Econômico e Financeiro, v. 124, 2001, p. 184

${ }^{6}$ INSTITUTO BRASILEIRO DE GEOGRAFIA E ESTATÍSTICA. As micro e pequenas empresas comerciais e de serviços no Brasil em 2001. Rio de Janeiro, 2003.
} 
- baixo investimento em inovação tecnológica;

- maior dificuldade de acesso ao financiamento de capital de giro; e

- relação de complementaridade e subordinação com as empresas de grande porte.

Nesse sentido, seriam consideradas micro ou pequenas empresas aquelas cuja organização empresarial fosse mais simplificada, aproximando-se da maioria dos critérios acima apontados. Contudo, muitas das características elencadas podem ser verificadas, também, em empresas de médio porte, não se prestando, pois, a mera análise dos itens sugeridos pelo IBGE como modo de classificação efetivo.

\subsection{Participação em âmbito nacional}

Em 2004 havia, no Brasil, 5.110.285 estabelecimentos formais do setor privado. Destes 5.028.318 - ou 98\% - são de micro e pequeno porte ${ }^{7}$. Estas empresas são responsáveis por $28 \%$ do faturamento da economia brasileira e respondem por $20 \%$ do Produto Interno Bruto (PIB) nacional ${ }^{8}$.

Com base nos dados disponíveis na Pesquisa Nacional por Amostra de Domicílios (PNAD), do IBGE, e na Relação Anual de Informações Sociais do Ministério do Trabalho e Emprego (RAIS/MTE), é possível afirmar que as atividades típicas de micro e pequenas empresas mantêm cerca de 35 milhões de pessoas ocupadas em todo o país, o equivalente a $59 \%$ das pessoas empregadas no Brasil.

Considerando-se também, além dos trabalhadores com registro em carteira, outras formas de ocupação, como a dos próprios empreendedores, familiares ocupados e

\footnotetext{
${ }^{7}$ Fonte: RAIS/ MTE (2004).

${ }^{8}$ Fonte: SERVIÇO BRASILEIRO DE APOIO ÀS MICRO E PEQUENAS EMPRESAS. As empresas de menor porte na economia nacional: alguns indicadores selecionados, 1991; SERVIÇO BRASILEIRO DE APOIO ÀS MICRO E PEQUENAS EMPRESAS. Coletânea estatística da micro e pequena empresa II, 2000; SERVIÇO BRASILEIRO DE APOIO ÀS MICRO E PEQUENAS EMPRESAS. Onde estão as micro e pequenas empresas no Brasil. BEDÊ, Marco Aurélio (coord.). São Paulo, 2006.
} 
trabalhadores sem registro, esse percentual sobe para $67 \%$ do total de ocupações geradas pelo setor privado da economia'.

\section{Participação das Micro e Pequenas Empresas na Economia Brasileira}

\begin{tabular}{|l|r|}
\hline Número de Empresas & $98 \%$ \\
\hline Pessoal Ocupado (formalmente) & $59 \%$ \\
\hline Pessoal Ocupado (total) & $67 \%$ \\
\hline Faturamento & $28 \%$ \\
\hline Participação no PIB & $20 \%$ \\
\hline Valor das Exportações & $2,7 \%$ \\
\hline
\end{tabular}

Fonte: SEBRAE-SP, RAIS/MTE, SEBRAE-NA e FUNCEX

Entre 2000 e 2004, conforme dados mais recentes, o número total de micro e pequenas empresas no país se expandiu em $22,1 \%$, contra um crescimento de $19,5 \%$ das médias e grandes empresas ${ }^{10}$.

\subsection{Participação no Estado de São Paulo ${ }^{11}$}

Somente no Estado de São Paulo existiam, no ano de 2004, mais de 1,5 milhão de empresas de menor porte ${ }^{12}$, o que corresponde a $99 \%$ do número de empresas instaladas, responsáveis por $70 \%$ da mão de obra empregada e 30\% do PIB do Estado.

\footnotetext{
${ }^{9}$ Fonte: SEBRAE-SP (2000).

${ }^{10}$ Fonte: SERVIÇO BRASILEIRO DE APOIO ÀS MICRO E PEQUENAS EMPRESAS. Onde estão as micro e pequenas empresas no Brasil. BEDÊ, Marco Aurélio (coord.). São Paulo, 2006.

${ }^{11}$ Fonte: SERVIÇO BRASILEIRO DE APOIO ÀS MICRO E PEQUENAS EMPRESAS. Participação das MPEs no total de pessoas ocupadas nas empresas paulistas: 1995/1999 (Relatório de Pesquisa). São Paulo, 2000; SERVIÇO BRASILEIRO DE APOIO ÀS MICRO E PEQUENAS EMPRESAS. Onde estão as micro e pequenas empresas no Brasil. BEDÊ, Marco Aurélio (coord.). São Paulo, 2006; SERVIÇO BRASILEIRO DE APOIO ÀS MICRO E PEQUENAS EMPRESAS, Guia básico sobre os pequenos negócios no Estado de São Paulo. $2^{\mathrm{a}}$ ed. rev. e ampl. BEDÊ, Marco Aurélio (org.). São Paulo, 2006.

${ }^{12}$ Formalmente constituídas. Estima-se que haja ao menos outras 2,6 milhões na informalidade.
} 
Para se ter ideia do impressionante crescimento do setor, em 1995, no Estado de São Paulo, 6,9 milhões de pessoas estavam ocupadas em atividades típicas de micro e pequenas empresas, representando $64 \%$ das pessoas ocupadas no setor privado (excluindo-se atividades agrícolas). Em 1999, este percentual atingiu 67\%, equivalente a 7,4 milhões de pessoas ocupadas. Houve, portanto, um crescimento na participação relativa da ordem de três pontos percentuais entre 1995 e 1999, correspondendo a um acréscimo de 500.000 pessoas.

Ressalte-se que esse aumento no número de pessoas ocupadas ocorreu concomitantemente com um processo de desaceleração da atividade econômica nacional, ou seja, a despeito da redução da atividade econômica ocorrida entre 1995 e 1999, as micro e pequenas empresas paulistas constituíram-se nas maiores geradoras de emprego.

Em contraposição, no mesmo período a participação relativa das médias e grandes empresas caiu de $36 \%$ para $33 \%$ do total de pessoas ocupadas, passando de 3.790.000 pessoas para 3.640.000 pessoas, ou seja, uma redução de cerca de 150.000 ocupações. Portanto, entre 1995 e 1999, o acréscimo líquido de novas ocupações nas empresas paulistas, de cerca de 350.000 vagas, foi obtido em grande parte por via da expansão dos negócios de micro e pequeno porte.

Percentual de pessoas ocupadas nas empresas paulistas em 1995 e 1999

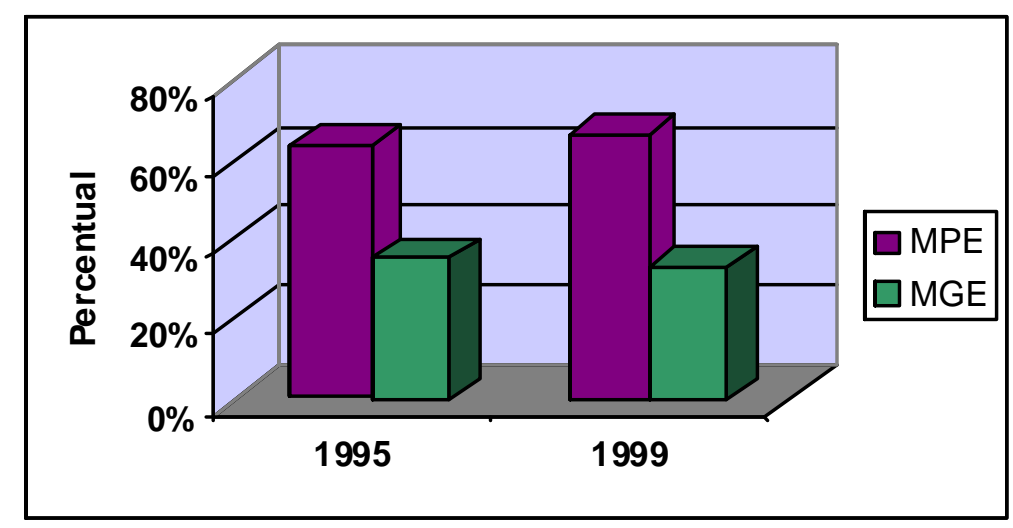

Fonte: SEBRAE, a partir de dados da PNAD e RAIS 
Número de pessoas ocupadas nas empresas paulistas em 1995 e 1999 (em milhões)

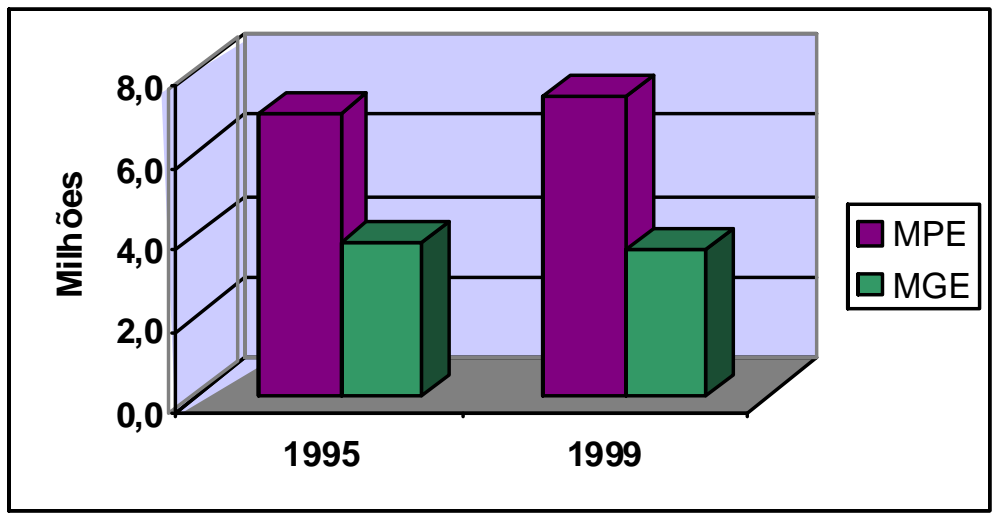

Fonte: SEBRAE, a partir de dados da PNAD E RAIS

Apenas o município de São Paulo responde por $35 \%$ do total de micro e pequenas empresas do Estado, conforme se verifica no gráfico abaixo:

Distribuição das Micro e Pequenas Empresas por setor de atividade Município de São Paulo e Estado de São Paulo

\begin{tabular}{|c|c|c|c|}
\hline \multirow{2}{*}{ Setor de Atividade } & \multicolumn{2}{|c|}{ MPEs } \\
& $\begin{array}{c}\text { Município de } \\
\text { São Paulo } \\
\text { (A) }\end{array}$ & $\begin{array}{c}\text { Estado de } \\
\text { São Paulo } \\
\text { (B) }\end{array}$ & (A)/(B) \\
\hline Indústria & 58.572 & 160.756 & $36 \%$ \\
Comércio & 170.137 & 562.929 & $30 \%$ \\
Serviços & 170.000 & 405.040 & $42 \%$ \\
\hline Total & $\mathbf{3 9 8 . 7 0 9}$ & $\mathbf{1 . 1 2 8 . 7 2 5}$ & $\mathbf{3 5 \%}$ \\
\hline
\end{tabular}

Fonte: SEBRAE, a partir de dados do CEE/TEM (dez/99) 


\subsection{Economia informal}

As estatísticas acima apresentadas referem-se exclusivamente à economia formal, ou seja, às empresas com registro nos órgãos competentes e inscrição no Cadastro Nacional de Pessoas Jurídicas (CNPJ), que engloba também as empresas individuais, equiparadas a pessoas jurídicas para fins de inscrição.

De acordo com informações do BNDES, foram identificadas 10.525.954 pequenas empresas não agrícolas em atividade no Brasil no ano de 2003. Destas, 98\% são consideradas "unidades do setor informal", assim entendidas aquelas caracterizadas pela produção em pequena escala, baixo nível de organização e pela quase inexistência de separação entre capital e trabalho enquanto fatores de produção, independentemente da existência ou não de registro formal. Ou seja, são pequenas empresas, regularizadas ou não.

Dentre as "unidades do setor informal", mais de 9 milhões não possuem registro - são as empresas comumente consideradas como integrantes da economia informal.

Existe, assim, um relevante setor informal, que não se regulariza principalmente em razão da burocracia atualmente existente e da elevada carga tributária ${ }^{13}$.

As empresas informais, apesar de, por um lado, beneficiarem a economia em razão da ocupação de pessoal e distribuição de renda, trazem enormes prejuízos globais

13 A Lei Complementar $n^{\circ} 128$, de 19.12.2008, criou a figura do Microempreendedor Individual (MEI), implantando condições especiais para legalização de algumas classes de trabalhadores informais com renda bruta anual de até $\mathrm{R} \$ 36.000,00$.

A formalização independe de registro no órgão registral próprio e é dispensada a manutenção de contabilidade, havendo apenas uma declaração anual de faturamento.

Demais disso, o microempreendedor registrado é enquadrado no Simples Nacional e fica isento dos impostos federais (Imposto de Renda, PIS, COFINS, IPI e CSLL), pagando apenas o valor fixo mensal de $11 \%$ do salário mínimo à Previdência Social, R\$ 1,00 a título de ICMS e R\$ 5,00 a título de ISS, conforme a atividade desenvolvida. Desse modo, o empreendedor tem acesso à cobertura previdenciária (auxílio-doença, aposentadoria por idade, salário-maternidade, pensão e auxílio reclusão) e pode registrar até um empregado, mediante recolhimento mensal de 3\% do salário mínimo à Previdência Social e $8 \%$ ao FGTS.

Tal medida foi um grande passo rumo à redução da informalidade, mas ainda tímida, vez que limita a possibilidade de crescimento do negócio em razão do valor limite para adesão e não garante à empresa os benefícios da pessoa jurídica.

Até o final de 2009, mais de 100 mil empreendedores já haviam aderido ao programa (Jornal da TardeEconomia, "São Paulo já tem 45 mil autônomos formalizados", 01.01.2010), o que indica a intenção dos empresários brasileiros de se formalizarem quando presentes condições mais benéficas e menos burocráticas. 
quando se computa a falta de recolhimento de tributos e os danos causados aos demais empresários em razão da concorrência desigual.

A informalização (ou economia subterrânea) não é fenômeno exclusivamente nacional, mas apresenta-se com maior força nos locais em que o grau de burocratização é mais elevado, com demonstrou o estudo do Banco Mundial sobre a proporção da economia informal em relação ao Produto Interno Bruto de alguns países ${ }^{14}$.

Combater a informalização sem, no entanto, desincentivar a iniciativa dos pequenos empresários é, pois, de suma relevância ao país, uma vez que não só gera significativo aumento na arrecadação tributária, mas também traz à formalidade milhões de empregados e empregadores, com os benefícios trabalhistas, previdenciários e sociais daí decorrentes. Contudo, não há hoje reais incentivos à formalização das empresas no Brasil.

Neste capítulo, procuramos traçar um panorama da extraordinária importância das micro e pequenas empresas, tanto em âmbito social quanto econômico. Esse fenômeno não é observado somente no Brasil, mas se espelha, em maior ou menor grau, em todo o mundo.

O fortalecimento dessas empresas mediante o fornecimento de incentivos e ampliação de crédito e, principalmente, os investimentos na desburocratização e facilitação da legalização dos pequenos empresários é, pois, um passo primordial para o crescimento econômico do país e para o desenvolvimento social.

Nessa linha, o presente estudo visa demonstrar a viabilidade e benefícios da sociedade unipessoal para organização das empresas de menor porte.

${ }^{14}$ WORLD BANK. World development report 2005: a better investment climate for everyone, 2005. 


\section{PESSOA JURÍDICA: EVOLUÇÃO DO CONCEITO}

Afirma Washington de Barros, ao comentar sobre o instituto da pessoa jurídica, que "[j]á se disse algures tratar-se de tema tormentoso, fascinante e sempre novo, devido às suas múltiplas, variadas e modernas aplicações. Cada dia que passa, novos e imprevistos horizontes se descortinam nesse proteiforme instituto jurídico" ${ }^{\text {.15. }}$

Diante da complexidade do tema, não se pretende, no presente capítulo, estudar a fundo a pessoa jurídica, mas sim promover uma breve digressão acerca da evolução do instituto e seu conceito, bem como abordar as diversas teorias quanto à sua natureza jurídica e à forma de aquisição e efeitos da personalização.

\subsection{Origem da pessoa jurídica}

Segundo Sylvio Marcondes ${ }^{16}$, a origem do vocábulo pessoa advém da palavra latina "persona", empregada para caracterizar as máscaras usadas pelos atores na representação de cenas e papéis em teatro, que cobriam seus rostos e eram providas de lâminas metálicas na cobertura ajustável aos lábios, de modo a tornar a voz mais sonora (per sonare). Como as máscaras eram sempre as mesmas para determinado papel representado, tal vocábulo passou a ser associado ao papel. Em seguida, foi vinculado ao próprio ator e estendido ao papel que todo indivíduo representa para si próprio e para a sociedade e, consequentemente, ao homem como sujeito de direitos e obrigações.

Partindo dessa ideia de pessoa chega-se, então, à noção de sujeito como o ser titular de direitos e de obrigações ${ }^{17}$.

$$
\begin{aligned}
& \text { Como ensina Ferrara }{ }^{18} \text {, } \\
& \text { "La moderna teoria delle persone giuridiche risulta dalla } \\
& \text { compenetrazione di tre fattori: il diritto romano, il diritto germanico, il }
\end{aligned}
$$

\footnotetext{
${ }^{15}$ MONTEIRO, Washington de Barros. Curso de direito civil: parte geral. 42a ed. São Paulo: Saraiva, 2009. p. 130 .

${ }^{16}$ MARCONDES MACHADO, Sylvio. Questões de direito mercantil. São Paulo: Saraiva, 1977. p. 167.

17 BEVILÁQUA, Clóvis. Código civil dos Estados Unidos do Brasil - comentado. $4^{\mathrm{a}}$ ed. Rio de Janeiro: Francisco Alves, 1993. v. 1. p. 167.

${ }^{18}$ FERRARA, Francesco. Teoria delle persone giuridiche. $2^{\mathrm{a}}$ ed. Riveduta. Torino: UTET, 1923. p. 21.
} 
diritto canonico - ognuno di questi ha elaborato una concezione autonoma più o meno sviluppata delle corporazioni o istituzioni - questi elementi si mescolano nel Medio Evo, ed è dal contatto e dal fermento intellettuale di questi diversi pensieri, che sorge una nuova concezione delle persone giuridiche."

O direito romano clássico ignora o conceito de pessoa jurídica. A concepção de sujeito de direito, de pessoa, tinha aplicação somente ao cidadão privado, sendo reconhecido ao Estado e alguns outros entes coletivos certo poder jurídico, mas não a qualidade de sujeito privado. O direito estatal era objetivo, não se podendo falar em personalidade do Estado, que era, sim, investido de uma subjetividade publicística por força da qual agia para persecução de seu escopo.

Os bens do Estado eram considerados res extra commercium e mesmo nas relações com os entes privados este mantinha sua soberania, não se separando o Estado soberano e legislador do Estado como sujeito ativo ou passivo de direitos patrimoniais.

Ressalte-se que algumas coletividades, como os collegi, apesar de aparentar semelhança com as pessoas jurídicas nada mais eram do que corpi pubblici, órgãos estatais dotados de certa autonomia. Seus bens eram provenientes de dotação do Estado, mantendo a característica de ager publicus. Também as civitates e municipia, originariamente cidades livres ou estados que perderam a existência política, faziam parte do Estado romano, o qual, por sua vez, lhes concedia alguma liberdade.

Pode-se afirmar, portanto, que no direito romano clássico as coletividades formavam uma unidade publicística, sendo partes destacadas ou derivadas do único, originário e soberano sujeito de todos os direitos públicos: o Estado ${ }^{19}$. Essa característica se manteve por todo o período da República e também durante parte do Império. As coletividades apresentavam-se sempre como entes públicos, em contraposição aos indivíduos.

Com o avanço do império romano e a constituição dos municípios italianos, surge a noção de pessoa jurídica como agrupamento (universitates) de pessoas ou coisas a que se atribui uma personalidade civil. Nas palavras de Vicente Ráo ${ }^{20}$, "foi sob a

\footnotetext{
${ }^{19}$ FERRARA, Francesco. Teoria delle persone giuridiche. $2^{\mathrm{a}}$ ed. Riveduta. Torino: UTET, 1923. pp. 26-28.

${ }^{20}$ RÁO, Vicente. O direito e a vida dos direitos. $4^{\text {a }}$ ed. São Paulo: RT, 1997. v. 2. p. 733.
} 
influência do direito público, ou melhor, à sombra e semelhança da organização unitária do Estado que em Roma nasceram os entes coletivos do direito privado, dotados de capacidade jurídica".

Uma vez reconhecida personalidade aos municípios, houve uma rápida difusão do instituto, que logo passa a ser estendido a todas as associações lícitas de interesse público como fato intrínseco. Não havia, pois, concessão de personalidade. Essa era decorrente da mera existência dos corpi pubblici.

Importante destacar que, já então, o corpus é uma unidade distinta e diversa de seus membros. A universitas como coisa ideal subsiste mesmo diante da alteração de integrantes e, ainda que composta por apenas um membro, com ele não se confunde. Trata-se de um novo indivíduo jurídico a que a lei reconhece direitos patrimoniais, como ocorre com os indivíduos naturais.

Contudo, nesse ponto ainda não se reconhecia personalidade às sociedades (societas), pois o direito as enxergava como uma relação meramente contratual e privada entre os seus sócios ${ }^{21}$, estes sim efetivos sujeitos de direitos. Para os romanos, a sociedade não existia externamente, perante terceiros, sendo apenas a relação entre seus membros ${ }^{22}$.

É no direito germânico que tem início a distinção entre o indivíduo como instituição e o indivíduo como parte de um órgão institucional. A pessoa é considerada de maneira autônoma, vez que suas vontades como indivíduo sejam diversas de suas vontades como integrante de um grupo.

Surgem, assim, os primeiros traços diferenciadores entre a pessoa natural e a pessoa coletiva, esboçados no direito romano.

Alguns doutrinadores afirmam que o direito alemão jamais chegou à concepção de um ente ideal distinto da coletividade dos indivíduos associados, vendo nas associações apenas uma pluralidade de pessoas com bens comuns e não um ente que se

${ }^{21}$ SERPA LOPES, Miguel Maria de. Curso de direito civil. $7^{\mathrm{a}}$ ed. Rio de Janeiro: Freitas Bastos, 1989. pp. 283-286.

${ }^{22}$ Embora os romanistas admitissem fosse a societas publicanorum dotada de personalidade jurídica, a concepção não tinha o sentido que atualmente se lhe atribui. Cf. FRANCO, Vera Helena de Mello; SZTAJN, Rachel. Direito empresarial. Sociedade anônima. Mercado de valores mobiliários. $2^{\mathrm{a}}$ ed. rev, atual. e ampl. São Paulo: RT, 2009. v. 2. p. 22. 
destaca desta pluralidade ${ }^{23}$. Outros, no entanto, como Heusler e Gierke, enxergavam nas associações de marca uma forma de pessoa jurídica ${ }^{24}$.

Nada obstante, a característica mais relevante é que se pode observar no direito germânico a ideia de organização corporativa. Neste ponto, cabe ressaltar os ensinamentos de Vera Helena de Mello Franco e Rachel Sztajn ${ }^{25}$ :

"A noção de universitas, corpus, collegium, apreendidas em novo contexto, não deixou de refletir a ênfase comunitária e coletiva do Direito Germânico, permitindo, ao depois, a visão da associação como um sujeito de direito com existência própria, distinta daquela dos membros que a compunham e isto fora do âmbito do Jus Publicum.

E embora o desenvolvimento do Direito Alemão das associações tenha sido interrompido com a recepção do Direito Romano, tal como advinda do pensamento dos pós glosadores e dos canonistas italianos, não se pode negar a contribuição posterior da Genossenschaftstheorie (teoria das associações) para a visão da sociedade de capitais como estrutura corporativa, organicamente constituída."

No direito canônico se desenvolveu de forma ainda mais efetiva a ideia da pessoa jurídica.

Com o fito de definir as instituições oficiais, unidades corporativas e patrimoniais que existiam na estrutura do catolicismo, o direito canônico exerceu grande

\footnotetext{
${ }^{23}$ FERRARA, Francesco. Teoria delle persone giuridiche. $2^{\mathrm{a}}$ ed. riveduta. Torino: UTET, 1923. p. 45.

${ }^{24}$ Nas associações de marca um grupo se estabelecia em determinado território, em geral delimitado por barreiras naturais, e o cultivava, formando a marca, a base econômica e jurídica da comunidade. $\mathrm{O}$ território se dividia em três partes: a vila, onde eram erigidas as casas dos moradores; os terrenos cultiváveis (Feldflur), divididos igualmente entre os integrantes da comunidade; e os bosques e pastos (Almend), de uso coletivo. A marca era comum a todos.

Para Heusler, as comunidades de marca eram pessoas jurídicas, e não comunhão in manu comune, já que os associados agiam sempre de forma coletiva, por meio de deliberações. A totalidade, como tal, seria sujeito de direito, ela teria a propriedade da marca, não os associados individualmente.

Gierke, por sua vez, entendia as comunidades de marca como uma forma de "pessoa jurídica com caráter coletivístico", uma personalidade coletiva que era ao mesmo tempo uma unidade jurídica e uma pluralidade coligada. Desse modo, algumas das faculdades da propriedade se concentrariam na personalidade coletiva, enquanto outras (em especial as de utilização) eram divididas entre os membros.

Cf. FERRARA, Francesco. Teoria delle persone giuridiche. $2^{\mathrm{a}}$ ed. riveduta. Torino: UTET, 1923. pp. 46 e ss.

${ }^{25}$ FRANCO, Vera Helena de Mello; SZTAJN, Rachel. Direito empresarial. Sociedade anônima. Mercado de valores mobiliários. $2^{\mathrm{a}}$ ed. rev, atual. e ampl. São Paulo: RT, 2009. v. 2. p. 25.
} 
influência, com a codificação dos institutos ${ }^{26}$. Os institutos da Igreja eram tidos como "entes ideais criados por vontade suprema" 27.

$\mathrm{Na}$ origem, o patrimônio era único, empregado de acordo com as necessidades da diocese, o que paulatinamente se desenvolveu de modo que aos entes eclesiásticos, fundações e ofícios passou a ser atribuída autonomia, verdadeira personalidade própria, independente da coletividade de pessoas.

\subsection{Evolução dos conceitos de personificação e limitação patrimonial}

Após o declínio do império romano e a relativa paz observada durante a Idade Média, a Europa experimentou um intenso crescimento comercial, especialmente a partir do século XI, facilitado pela multiplicação das cidades livres e a aberturas de novas vias de circulação.

O comércio, ou mercancia, era, então, exercido por profissionais especializados, no âmbito das corporações de ofício. O mercador era responsável pela organização do capital e do trabalho em seus negócios, assumindo integralmente os riscos e, na maior parte das vezes, realizando o trabalho pessoalmente, secundado por poucos auxiliares, em geral seus familiares. Assim, o capital exigido para exercício da atividade mercantil era reduzido. A empresa, em regra, extinguia-se com a morte do mercador ${ }^{28}$.

Com o desenvolvimento das atividades econômicas, a sociedade foi se tornando cada vez mais complexa, exigindo a concentração de grandes recursos para o êxito empresarial, de modo que o capital individual passa a ser insuficiente.

O indivíduo, por si só incapaz de realizar certos fins que ultrapassam suas forças e os limites da vida individual, vê-se impelido a unir-se a outros homens, formando

${ }^{26}$ FRONTINI, Paulo Salvador. "Pessoas jurídicas no código civil de 2002 - elenco, remissão histórica e disposições gerais". In: Revista de Direito Mercantil Industrial, Econômico e Financeiro, v. 137, 2005. pp. $94-95$.

${ }^{27}$ RÁO, Vicente. O direito e a vida dos direitos. $4^{\text {a }}$ ed. São Paulo: RT, 1997. v. 2. p. 734.

${ }^{28}$ MUNHOZ, Eduardo Secchi. Empresa contemporânea e o direito societário. São Paulo: Juarez de Oliveira, 2002. p. 52. 
associações dotadas de estrutura própria e personalidade privativa, com as quais supera a debilidade de suas forças e a brevidade de sua vida ${ }^{29}$.

Paralelamente à premência da união de pessoas e recursos para possibilitar empresas de maior vulto, contudo, surge a necessidade de preservação dos bens pessoais dos envolvidos em tais projetos. Prudentemente, as pessoas desejavam comprometer apenas uma parcela de sua riqueza para ventura em determinado empreendimento, cujo desenrolar é sempre incerto e cujo fracasso poderia gerar a ruína dos envolvidos que nele houvessem aplicado os proventos obtidos ao longo de toda uma existência.

Essa situação deu azo à exigência de imputação de direitos e obrigações a entes outros que não as pessoas físicas e organismos públicos, até então titulares quase que absolutos dos mesmos, acarretando, inclusive, na possibilidade de autonomia patrimonial.

\section{Como bem sintetizou Eduardo Secchi Munhoz ${ }^{30}$ :}

"Os sistemas jurídicos clássicos tinham como preocupação central os comportamentos humanos $e$ as relações entre os indivíduos, considerando apenas marginalmente os fenômenos associativos. Contudo, com a profusão do desenvolvimento de entidades coletivas, especialmente aquelas voltadas para o exercício da atividade empresarial, foi inevitável o desenvolvimento do instituto da personalidade jurídica, pelo qual essas coletividades se transformaram em centros autônomos de imputação de direitos e obrigações. Assim, o século XIX viveu o fenômeno da generalização da personificação societária, pelo qual o instituto da pessoa jurídica, anteriormente reservado à Igreja, à Comuna e às demais entidades havidas como transcendentes ao indivíduo, tanto no tocante à duração como aos fins perseguidos, passou a ser adotado em relação às entidades privadas, organizadas para o exercício da atividade empresarial."

O avanço na disciplina da personalização permitiu a evolução e ampliação das atividades empresariais, especialmente quando também se desenvolveram os sistemas

\footnotetext{
${ }^{29}$ MONTEIRO, Washington de Barros. Curso de direito civil: parte geral. 42a ed., São Paulo: Saraiva, 2009. p. 130.

${ }^{30}$ MUNHOZ, Eduardo Secchi. Empresa contemporânea e o direito societário. São Paulo: Juarez de Oliveira, 2002. p. 64.
} 
de limitação de responsabilidade dos sócios, ao qual a personalização está intrinsecamente $\operatorname{ligada}^{31}$.

\subsection{Natureza jurídica}

$\mathrm{Na}$ medida em que o direito reconhecia personalidade às diferentes formas associativas, surgiram teorias variadas a respeito da natureza das pessoas jurídicas. $\mathrm{O}$ assunto deu origem, ao longo do tempo, a literatura vastíssima e grande diversidade de posicionamentos.

Dentre as principais teorias, destacamos a da ficção legal, da pessoa jurídica como realidade objetiva, da pessoa jurídica como realidade técnica e a teoria institucionalista, as quais já foram exaustivamente debatidas e das quais trataremos apenas de forma sintética.

\subsubsection{Teoria ficcionista}

Desenvolvida por Savigny, teve por base a teoria de Windscheid sobre o direito subjetivo. Prevalente na Alemanha e França no século XIX, a teoria da ficção foi grandemente influenciada pelo momento histórico, em que o homem era tido como centro natural de direitos e deveres e, portanto, o único sujeito de direito por natureza.

Por outro lado, no entanto, a situação econômica da Alemanha pré-industrial demandava instrumentos capazes de agregar recursos. A conjunção de fatores obrigava o reconhecimento da pessoa jurídica como centro de imputação de direito e deveres, passando Savigny a defender a ideia de que as pessoas jurídicas teriam existência fictícia, puramente abstrata, sendo meramente uma criação do direito ${ }^{32}$.

\footnotetext{
31 "É bem verdade que personalidade jurídica e responsabilidade limitada não são inseparáveis. São conhecidos tipos societários dotados de personalidade jurídica com responsabilidade ilimitada (v.g., na lei brasileira, a sociedade em nome coletivo) e, por outro lado, sociedades sem personalidade jurídica com responsabilidade limitada (v.g., na lei brasileira, a sociedade em conta de participação). A personificação da sociedade comercial foi, por excelência, a técnica utilizada para a introdução do princípio da responsabilidade limitada no exercício da atividade empresarial." Cf. MUNHOZ, Eduardo Secchi. Empresa contemporânea e o direito societário. São Paulo: Juarez de Oliveira, 2002. pp. 69-70.
}

${ }^{32}$ SALOMÃO FILHO, Calixto. A sociedade unipessoal. São Paulo: Malheiros, 1995. pp. 16-17. 
O uso da ficção seria um meio de afirmar o caráter artificial da pessoa jurídica sem negar a realidade do fenômeno associativo. Uma vez que a constituição de um ente coletivo sempre ocorrerá por meio dos homens, se pretende que estes fenômenos são iguais aos homens e, portanto, sujeitos de direito. A pessoa jurídica decorreria, pois, de uma ficção legal; diferentemente da pessoa natural, que seria uma criação da natureza.

Conforme assinala Miguel Reale, "preferiu Savigny ver no conceito de pessoa jurídica mais um exemplo de fictio juris, existente apenas como artifício técnico imposto pelas necessidades da vida em comum" ${ }^{33}$. Para este jurista, a caracterização da pessoa jurídica como simples ficção traz sérias dificuldades no que tange à limitação da responsabilização dos sócios pelas dívidas sociais.

Demais disso, como salienta Venosa ${ }^{34}$, a teoria ficcionista não justifica a atribuição de personalidade ao Estado que, em última instância, determina serem os homens sujeitos de direito (já que essa qualidade na pessoa física não é exigência universalmente reconhecida).

Bastante próxima à teoria ficcionista de Savigny encontra-se a teoria normativista de Hans Kelsen. Ele parte da ideia de que não existe pessoa como uma realidade natural, pois a pessoa é, sempre, centro de imputações normativas, uma construção jurídica criada pela ciência do Direito. O Direito, então, cria o conceito de pessoa como "portador" de direitos e deveres jurídicos, indistintamente, seja um indivíduo ou uma entidade.

Para Kelsen, a pessoa jurídica consistiria justamente na personificação de uma ordem jurídica, a qual confere direitos e deveres aos indivíduos e órgãos integrantes das corporações, constituídas por meio de um estatuto. Desse modo, os deveres e direitos da pessoa jurídica não passam da disciplina jurídica estabelecida para as condutas dos homens individuais, pertencendo, ainda, o patrimônio da pessoa jurídica aos homens que a constituem $^{35}$.

\footnotetext{
${ }^{33}$ REALE, Miguel. Lições preliminares de direito. 16a ed. São Paulo: Saraiva, 1988. p. 230.

${ }^{34}$ VENOSA, Silvio de Salvo. Direito civil: parte geral. $6^{\text {a }}$ ed. São Paulo: Atlas, 2006. v. 1. p. 235.

${ }^{35}$ KELSEN, Hans. Teoria pura do direito. São Paulo: Martins Fontes, 1998. pp. 191 e ss.
} 
Assim, pode-se afirmar que, para aquele autor, as pessoas jurídicas seriam apenas "conjuntos normativos", ou meros "centros de imputação"36.

A propósito da teoria de Kelsen, anota Fábio Konder Comparato $^{37}$ :

"Se as ideias de Kelsen não foram aceitas integralmente por ninguém, é preciso, no entanto, reconhecer que elas exerceram, e continuam a exercer, a importante função de uma espécie de detergente do pensamento jurídico, ajudando-o, de fato, a purificar-se de um certo número de ilusões. Não se pode deixar de reconhecer que, a partir de Kelsen, a teoria da pessoa jurídica jamais voltará a ser o que era antes."

\subsubsection{Pessoa jurídica como realidade objetiva}

Tendo como principal representante Gierke e sua Genossenschaftstheorie ${ }^{38}$, a teoria da realidade objetiva atribui à pessoa jurídica pouca importância, sendo mais relevante a realidade que está na base deste instituto.

A simples manifestação de vontade, seja pública ou privada, seria, por si só, capaz de dar vida a uma entidade com existência própria, autônoma com relação aos seus membros, com capacidade de se tornar sujeito de direito.

Desse modo, sempre que os homens se reunissem para realizar qualquer objetivo, de natureza política, comercial, civil, estética ou religiosa, formar-se-ia efetivamente uma entidade nova; constituir-se-ia um grupo que possui existência inconfundível com a de seus membros ${ }^{39}$.

A crítica que se coloca à teoria organicista é que a mesma parte do reconhecimento da capacidade jurídica para somente depois chegar à justificativa da

\footnotetext{
${ }^{36}$ REALE, Miguel. Lições preliminares de direito. 16 ${ }^{\mathrm{a}}$ ed. São Paulo: Saraiva, 1988. p. 234.

${ }^{37}$ COMPARATO, Fábio Konder. O poder de controle na sociedade anônima. São Paulo: RT, 1976. pp. 276-277.

${ }^{38}$ Teoria das Corporações, em que Gierke critica o individualismo burguês, de inspiração francesa, por entender que o mesmo levaria ao reconhecimento do poder absoluto do Estado ao lado de uma soma de vontades autônomas dos indivíduos.

${ }^{39}$ REALE, Miguel. Lições preliminares de direito. $16^{\mathrm{a}}$ ed. São Paulo: Saraiva, 1988. pp. 230-231.
} 
realidade existente, ou seja, pretende-se que a capacidade de ter vontade própria atribui realidade ao fenômeno associativo, que seria o único parâmetro para atribuição da personalidade jurídica ${ }^{40}$.

\subsubsection{Pessoa jurídica como realidade técnica}

Guardando traços das teorias da ficção e da realidade objetiva ${ }^{41}$, concebe a pessoa jurídica como um expediente de ordem técnica, útil para alcançar indiretamente alguns interesses humanos e ampliando os meios de ação destes. A pessoa jurídica seria uma realidade, e não uma ficção; mas uma realidade técnica, e não sociológica ${ }^{42}$, com existência diversa da das pessoas naturais que a integram.

Assim como o Direito reconhece personalidade ao ser humano isoladamente, a personalidade deve ser atribuída de maneira autônoma aos agrupamentos humanos cujos interesses transcendem a esfera individual. O Direito deve proteger os interesses e a atuação do grupo social, mediante um corpo ideal coletivo com objetivo unificado, diferente da vontade individual de seus membros e com uma organização capaz de expressar a vontade coletiva ${ }^{43}$.

A maior parte da doutrina ${ }^{44}$ considera que o Código Civil brasileiro adotou a teoria da realidade técnica, uma vez que prevê o início da existência legal da pessoa jurídica de direito privado com a inscrição de seu ato constitutivo em registro próprio e na forma da lei ${ }^{45}$, sendo convertidos em pessoa jurídica apenas os entes que, além do substrato de sua existência (atos constitutivos), cumpram os comandos legais.

\footnotetext{
${ }^{40}$ SALOMÃO FILHO, Calixto. A sociedade unipessoal. São Paulo: Malheiros, 1995. pp. 20-22.

${ }^{41}$ MONTEIRO, Washington de Barros. Curso de direito civil: parte geral. 42a ed. São Paulo: Saraiva, 2009. p. 135.

${ }^{42}$ RODRIGUES, Silvio. Direito civil. $25^{\mathrm{a}}$ ed. atual. São Paulo: Saraiva, 1995. v. 1. p. 66.

${ }^{43}$ VENOSA, Silvio de Salvo. Direito civil: parte geral. 6 a ed. São Paulo: Atlas, 2006. v. 1. p. 237.

${ }^{44}$ Veja-se, por exemplo, VENOSA, Silvio de Salvo. Direito civil: parte geral. $6^{a}$ ed. São Paulo: Atlas, 2006. v. 1. p. 240 e PEREIRA, Caio Mário da Silva. Instituições de direito civil. 12a ed. Rio de Janeiro: Forense, 1991. v. 1. pp. 209-210.

${ }^{45}$ Código Civil, Art. 45. Começa a existência legal das pessoas jurídicas de direito privado com a inscrição do ato constitutivo no respectivo registro, precedida, quando necessário, de autorização ou aprovação do Poder Executivo, averbando-se no registro todas as alterações por que passar o ato constitutivo.
} 


\subsubsection{Teoria institucionalista}

Desenvolvida por Maurice Hauriou, prega que a instituição preexiste ao momento em que nasce a pessoa jurídica. Por tratar-se de uma organização com fins comuns aos membros que a compõem, seria o grau de concentração e de organização que converteria automaticamente a instituição em pessoa jurídica ${ }^{46}$.

Hauriou enxergava as instituições sociais como produtos da força criativa da humanidade ${ }^{47}$ :

"Une institution est une idée d'œuvre ou d'entreprise qui se réalise et dure juridiquement dans un milieu social; pour la réalisation de cette idée, un pouvoir s'organise qui lui procure des organes; d'autre part, entre les membres du groupe social intéressé à la réalisation de l'idée, il se produit des manifestations de communion dirigées par les organes $d u$ pouvoir et réglées par des procédures."

A definição de Hauriou visa a aplicar-se a todos os tipos de fenômenos associativos, de modo que as instituições seriam formadas por três elementos: (a) a ideia de uma obra ou empresa a ser realizada em um grupo social; (b) o poder organizado colocado a serviço desta ideia para sua realização; e (c) as manifestações de concordância que ocorrem dentro do grupo social com relação à ideia e sua realização.

Uma vez presentes esses elementos, teria início o processo de fundação da instituição, mediante interiorização da ideia do trabalho do grupo, que começa em certo momento de "crise" inicial em que esta ideia, que formará a base da instituição, se cristaliza em determinado grupo. Em seguida, vem a incorporação, em que o elemento do poder organizado e o elemento de manifestações de concordância que ocorrem dentro do grupo são interiorizados na ideia do trabalho. Finalmente, viria a personificação, estágio no qual os membros são absorvidos na ideia do trabalho, os órgãos desenvolvem um poder de realização e a comunhão do grupo se mostra no que Hauriou chama de "manifestações físicas".

\footnotetext{
${ }^{46}$ RODRIGUES, Silvio. Direito civil. 25a ed. atual. São Paulo: Saraiva, 1995. v. 1. pp. 66-67.

${ }^{47}$ HAURIOU, Maurice. "La théorie de l'institution et de la fondation: essay de vitalisme social". In : La cité moderne et les transformations du droit, Cahiers de la nouvelle journée n. 4. Paris: Bloud et Gay, 1925. p. 10.
} 
Essa teoria distingue dois tipos de unidade: a física, em que há um todo homogêneo, cujas partes não apresentam entre si diferenças fundamentais ou relevantes, e a finalística, que se estabelece mediante a complementação de partes diferençadas. Assim, nas palavras de Miguel Reale, "a pessoa jurídica é uma existência, mas uma existência teleológica, ou seja, finalística" ${ }^{, 48}$.

No Brasil, a teoria institucionalista é defendida por Fran Martins, que afirma: “[d]á-se, desse modo, à sociedade comercial a natureza de instituição em vez de contrato, como sempre foi considerada."49 (grifos do original)

\subsection{O conceito de pessoa jurídica no ordenamento brasileiro}

No Brasil, até 1916, havia apenas leis esparsas com relação às pessoas jurídicas, como a Consolidação das Leis Civis de 1857, que referia como pessoas collectivas as cidades, villas, concelhos, confrarias, cabidos, prio e convento, marido e molher, irmãos em uma herança e outras semelhantes, e a Lei ${ }^{\circ} 173$, de 10.09.1893, que regulou "a organisação das associações que se fundarem para fins religiosos, moraes, scientificos, artísticos, políticos ou de simples recreio".

Teixeira de Freitas, em seu projeto para o Código Civil, que não prosperou, previu a conceituação de pessoas jurídicas de existência necessária e de existência possível. Já as fundações eram reconhecidas, porém não estavam previstas no ordenamento então vigente ${ }^{50}$.

O Código Comercial de 1850 dispunha sobre as sociedades comerciais, mas sem, no entanto, associá-las à pessoa jurídica. Isso porque estas eram tidas como formas

\footnotetext{
${ }^{48}$ REALE, Miguel. Lições preliminares de direito. $16^{\mathrm{a}}$ ed. São Paulo: Saraiva, 1988. pp. 231-232.

${ }^{49}$ MARTINS, Fran. "Sociedade por quotas unipessoal”. In: Novos estudos de direito societário. São Paulo: Saraiva, 1988. p. 269.

${ }^{50}$ FRONTINI, Paulo Salvador. "Pessoas jurídicas no código civil de 2002 - elenco, remissão histórica e disposições gerais". In: Revista de Direito Mercantil Industrial, Econômico e Financeiro, v. 137, 2005. pp. 97-98.
} 
associativas não corporificadas, configurando-se como mero contrato ou relação obrigacional e, portanto, não dotadas de estrutura corporativa ${ }^{51}$.

Ao tratar das sociedades anônimas, a Lei $\mathrm{n}^{\circ}$ 556, de 1850 já determinava a limitação da responsabilidade dos acionistas da companhia ao valor das ações ou "do interesse por que se houverem comprometido" (art. 298), porém de forma sumária.

Foi, pois, o Código Civil de 1916 o primeiro a sistematizar a matéria e tratar de forma mais ampla das pessoas, natural e jurídica, como sujeitos de direitos e obrigações. Nessa esteira, o Código estabeleceu a diferenciação da existência da pessoa jurídica e de seus membros, reconhecendo-a como sujeito de direitos e obrigações.

Assim como ocorre com a pessoa natural, o Código Civil de 1916 previu a necessidade da pessoa jurídica de ter nome próprio, registro e domicílio, a validade da vontade manifestada por seus órgãos societários e seu patrimônio, além da forma de sua extinção e sucessão. Todavia, não trouxe o codex o conceito de pessoa jurídica.

E, com apenas pequenas modificações no regime jurídico, o Código Civil atual, de 2002, segue a mesma sistemática.

Desse modo, a conceituação de pessoa jurídica no direito brasileiro é formada predominantemente pela doutrina.

Para Orlando Gomes" 52 pessoas jurídicas são "entes formados pelo agrupamento de homens, para fins determinados, que adquirem personalidades distintas dos seus membros. Reconhece-lhes, a lei, capacidade de ter direitos e contrair deveres."

Limongi França $\mathrm{a}^{53}$ as conceitua como "a união moral de pessoas reunidas com o objetivo de alcançar um fim comum e reconhecida pelo ordenamento como sujeito de direito."

Assim, verifica-se que a doutrina coloca a pessoa jurídica como a organização de pessoas que se reúnem e conjugam esforços visando a um fim comum.

\footnotetext{
${ }^{51}$ Ressalte-se que em alguns países as sociedades de pessoas jamais adquirem personalidade jurídica, como na Itália (società semplice, società in nome collettivo, società in accomanditta semplice) e Alemanha (Gesellschaft bürgerlichen Rechts, Offene Handelsgesellschaft, Kommanditgesellschaft).

${ }^{52}$ GOMES, Orlando. Introdução ao direito civil. $10^{\text {a }}$ ed. Rio de Janeiro: Forense, 1991. p. 191.

${ }^{53}$ LIMONGI FRANÇA, Rubens. Instituições de direito civil. $4^{\mathrm{a}}$ ed. atual. São Paulo: Saraiva, 1996. p. 65.
} 
Desse modo, além da reunião de pessoas é necessária uma vinculação psíquica entre os que a constituem para que surja uma pessoa desvinculada da vontade e da autonomia de seus próprios membros ${ }^{54}$. Com isto, surge a concepção de personificação do ente abstrato para criar uma vontade diversa da de seus membros.

Como acentua Pontes de Miranda ${ }^{55}$, a pessoa jurídica é criação do mundo jurídico: seu conceito e disciplina advêm do Direito. O sistema jurídico atribui, a partir do suporte fático, direitos, deveres, pretensões, obrigações, ações e exceções a entes humanos ou entidades por estes criadas. No caso de pessoas jurídicas, o suporte fático consiste na criação do homem, na formação de sociedades e associações (personificadas) e nas fundações.

Diante da construção doutrinária, é possível afirmar que a pessoa jurídica é uma criação do Direito, definida a partir da identificação do interesse coletivo com a formação de grupos associativos para atingir uma finalidade própria.

O ordenamento jurídico reconhece esse agrupamento como pessoa e destina-lhe um tratamento peculiar, de modo similar ao das pessoas físicas ${ }^{56}$, permitindo que se relacione com a sociedade e exteriorize a sua vontade de forma autônoma. Ou, como sintetizou Rachel Sztajn ${ }^{57}$ :

“(...) as pessoas jurídicas são fruto da combinação da engenhosidade do homem com o direito, que, por força de seu reconhecimento, as incorpora ao sistema e que, quanto ao escopo que fomenta sua organização, desempenham função socialmente relevante, função esta que se acentua na medida em que se atente para o papel desempenhado no que concerne ao desenvolvimento econômico."

\footnotetext{
${ }^{54}$ VENOSA, Silvio de Salvo. Direito civil: parte geral. 6 a ed. São Paulo: Atlas, 2006. v. 1. p. 230.

${ }^{55}$ PONTES DE MIRANDA, Francisco Cavalcanti. Tratado de direito privado. Rio de Janeiro: Borsoi, 1954. t. I, v. 1. pp. 281-286.

${ }^{56}$ Tavares Borba constrói o conceito de pessoa jurídica a partir da comparação com o de pessoa natural.

Cf. TAVARES BORBA, José Edwaldo. Direito societário. 4a ed. Rio de Janeiro: Freitas Bastos, 1998. p. 32.

57 SZTAJN, Rachel. "Terá a personificação das sociedades função econômica?". In: Direito empresarial: aspectos atuais de direito empresarial brasileiro e comparado. São Paulo: Método, 2005. pp. 377-378.
} 


\subsection{Forma de aquisição da personalidade}

As partes que celebram um contrato de sociedade estão legalmente obrigadas a proceder à sua formalização. É o que dispõe o Artigo 967 do Código Civil, verbis:

"É obrigatória a inscrição do empresário no Registro Público de Empresas Mercantis da respectiva sede, antes do início de sua atividade."

A formalização se dá mediante registro dos atos constitutivos da sociedade - quais sejam, o contrato ou estatuto social - no registro competente. Para as sociedades empresárias $^{58}$, o arquivamento dos atos constitutivos é feito junto ao Registro Público de Empresas Mercantis, através das Juntas Comerciais, que são órgãos estatais, sob supervisão do Departamento Nacional de Registro do Comércio, por sua vez vinculado ao Ministério do Desenvolvimento, Indústria e Comércio Exterior. Para as sociedades simples $^{59}$, o arquivamento deve ser feito junto ao Registro Civil de Pessoas Jurídicas.

Somente a partir da formalização, mediante registro, é que a sociedade adquire personalidade, surgindo, então, a pessoa jurídica.

Dependendo do propósito da sociedade, o regular funcionamento está sujeito também à necessária autorização governamental, que deve ser obtida anteriormente ao registro. A autorização faz-se necessária em razão das relevantes implicações que o exercício de certas atividades traz à coletividade, situação esta que demanda uma prévia verificação das condições daquela sociedade para o exercício das atividades pretendidas. É o caso, por exemplo, das sociedades estrangeiras ${ }^{60}$, das instituições financeiras ${ }^{61}$, das sociedades seguradoras ${ }^{62}$ e das entidades de previdência privada ${ }^{63}$.

\footnotetext{
${ }^{58}$ Nos termos do Artigo 982 do Código Civil, "considera-se empresária a sociedade que tem por objeto o exercício de atividade própria de empresário sujeito a registro".

${ }^{59}$ São consideradas sociedades simples todas aquelas que não tenham por objeto o exercício de atividade própria de empresário (art. 982).

${ }^{60}$ Art. 1.134 do Código Civil.

${ }^{61}$ Arts. 18 e 19 da Lei n ${ }^{\circ}$ 4.595/64.

${ }^{62}$ Art. 24 do Decreto-Lei n ${ }^{\circ}$ 73/66 e art. 42 do Decreto n ${ }^{\circ}$ 60.459/67.

${ }^{63}$ Art. 33 da Lei Complementar $n^{\circ}$ 109/01.
} 
A alguns tipos de pessoas jurídicas a lei impõe a necessidade de registro em outro órgão além do registro civil ou empresarial; porém, diferentemente da autorização governamental, tal registro tem apenas finalidade cadastral e de reconhecimento de validade de atuação, como é o caso dos partidos políticos, que podem ser criados livremente, independentemente de autorização, mas devem ser inscritos no Tribunal Superior Eleitoral ${ }^{64}$.

Na vigência do Código Civil de 1916, alguns juristas renomados, como Carvalho de Mendonça ${ }^{65}$, defendiam que as sociedades existiam como pessoas jurídicas desde sua constituição, nada obstante a clareza dos dispositivos contidos nos Artigos 18 e $20, \S 2^{\circ}$ daquele diploma legal:

Art. 18. "Começa a existência legal das pessoas jurídicas de direito privado com a inscrição dos seus contratos, atos constitutivos, estatutos ou compromissos no seu registro peculiar (...)".

Art. 20, $\S 2^{\circ}$. "As sociedades enumeradas no art. 16 que, por falta de autorização ou de registro, se não reputarem pessoas jurídicas, não poderão acionar a seus membros, nem a terceiros, mas estes poderão responsabilizá-las por todos os seus atos." (grifamos).

Questionava Carvalho de Mendonça ${ }^{66}$ :

"as restrições mediante as quais as leis procuram dificultar a existência das sociedades irregulares afetam-lhes porventura a personalidade jurídica? Absolutamente não. Personalidade jurídica significa capacidade para ter direitos patrimoniais, quer dizer, autonomia patrimonial."

Tal posição se embasava no fato do Código Civil de 1916 prever, em seu Art. $16, \S 2^{\circ}$, que as sociedades mercantis continuariam a reger-se pelas leis comerciais. O Código Comercial, por sua vez, determinava que as sociedades comerciais teriam

\footnotetext{
${ }^{64}$ Cf. Art. 17, $\S 2^{\circ}$ da Constituição Federal e Art. $7^{\circ}$ da Lei $n^{\circ}$ 9.096/95.

65 CARVALHO DE MENDONÇA, José Xavier. Tratado de direito comercial brasileiro. $4^{\mathrm{a}}$ ed. Rio de Janeiro: Freitas Bastos, 1945. t. III, v. III.

${ }^{66}$ CARVALHO DE MENDONÇA, José Xavier. Tratado de direito comercial brasileiro. $4^{\mathrm{a}}$ ed. Rio de Janeiro: Freitas Bastos, 1945. t. III, v. III. pp. 89-91.
} 
personalidade jurídica desde sua constituição, e não apenas com o registro, como nas sociedades civis.

Era, de qualquer forma, posição minoritária, defendendo a maioria dos juristas que o início da personalidade jurídica de qualquer sociedade, qualquer que fosse seu propósito, dar-se-ia com o arquivamento de seus atos constitutivos no registro competente.

Quando da elaboração do Anteprojeto de Código Civil Sylvio Marcondes tratou de esclarecer a controvérsia ${ }^{67}$ :

"A personificação, fenômeno posterior, do qual a existência da sociedade é pressuposto, constitui a fonte geratriz de um novo sujeito de direito, capacitado a ser titular do patrimônio especial que, previamente, composto pelas partes separadas dos patrimônios individuais dos sócios, se desliga da titularidade destas, para transformar-se em patrimônio autônomo, objeto de nova titularidade."

Atualmente os Artigos $45^{68}$ e $985^{69}$ do Código Civil deixam evidente que a aquisição da personalidade jurídica se dá apenas com o registro, não havendo mais campo para tal discussão.

Vale ressaltar que, nos termos do Artigo 1.151 do Código Civil, caso o arquivamento dos atos constitutivos seja requerido no prazo de até 30 (trinta) dias da data de constituição da sociedade, o registro - e com ele a aquisição de personalidade jurídica retroagirá à data da constituição. Porém, se a empresa for registrada após esse prazo, o registro e a consequente aquisição de personalidade jurídica se dão apenas na data do efetivo arquivamento, permanecendo a sociedade, até então, no âmbito das sociedades em comum.

67 MARCONDES MACHADO, Sylvio. "Exposição de motivos complementar". In: Código civil: anteprojetos. Senado Federal, 1973, t. 2, v. 5. p. 202.

${ }^{68}$ Código Civil, Art. 45. Começa a existência legal das pessoas jurídicas de direito privado com a inscrição do ato constitutivo no respectivo registro, precedida, quando necessário, de autorização ou aprovação do Poder Executivo, averbando-se no registro todas as alterações por que passar o ato constitutivo.

${ }^{69}$ Código Civil, Art. 985. A sociedade adquire personalidade jurídica com a inscrição, no registro próprio e na forma da lei, dos seus atos constitutivos. 
Portanto, verifica-se que a existência da sociedade é um momento anterior à pessoa jurídica, de modo que é possível haver sociedades não formalizadas - e que, portanto, não têm personalidade jurídica - mas que tenham repercussão jurídica. Nas palavras de Pontes de Miranda: “[n]ão há personificação antes da criação, mas pode criar-se a sociedade sem ela vir a ter personalidade."70

Assim, pode-se afirmar que a sociedade existe desde o ato volitivo dos sócios que lhe deu origem. O registro é apenas declaratório da existência da sociedade, porém constitutivo da pessoa jurídica ${ }^{71}$.

Há, todavia, sociedades sem personalidade jurídica, como as sociedades de fato, irregulares e/ou em comum e a sociedade em conta de participação, reconhecidas pelo direito pátrio.

\subsubsection{Sociedades em comum}

Às sociedades que não tiveram seus atos constitutivos regularmente registrados e, portanto, não adquiriram personalidade jurídica, a doutrina denominou "sociedades irregulares" ou "sociedades de fato",72, posto não existirem juridicamente, mas

${ }^{70}$ PONTES DE MIRANDA, Francisco Cavalcanti. Tratado de direito privado. $3^{\mathrm{a}}$ ed. Rio de Janeiro: Borsoi, 1972. t. XLIX. p. 61.

${ }^{71}$ À exceção das sociedades em conta de participação, como se verá no item 2.5.2 adiante.

${ }^{72}$ Não obstante trazerem os mesmos efeitos jurídicos, qual seja a ausência de personalização e as consequências daí decorrentes, alguns doutrinadores diferenciam a sociedade irregular e a sociedade de fato.

A diferenciação mais aceita é a proposta por Waldemar Ferreira, que entende como sociedade irregular aquela que possui atos constitutivos escritos, mas por algum motivo não os registrou, e como sociedade de fato aquela que sequer possui atos constitutivos escritos. (Cf. FERREIRA, Waldemar. Instituições de direito comercial. Rio de Janeiro: Freitas Bastos, 1944. v. 1. p. 255)

Para Carvalho de Mendonça, as sociedades irregulares seriam aquelas que funcionam sem o cumprimento das solenidades legais da constituição, registro e publicidade, enquanto as sociedades de fato seriam aquelas afetadas por vícios que as tornariam nulas. (Cf. CARVALHO DE MENDONÇA, José Xavier. Tratado de direito comercial brasileiro. $4^{\mathrm{a}}$ ed. Rio de Janeiro: Freitas Bastos, 1945. t. III, v. III. p. 131)

Finalmente, para Fran Martins a sociedade irregular é aquela que, apesar de ter seus atos jurídicos registrados - e ter, portanto, adquirido personalidade jurídica - descumpre alguma obrigação legal, tornandose irregular (como a sociedade que continua existindo após término do prazo contratual previsto); já a sociedade de fato seria tanto aquela que não se forma por escrito quanto a que possui atos constitutivos escritos, mas não os arquivou no registro competente. De acordo com a posição de Fran Martins, apenas as sociedades de fato seriam entes despersonalizados, sujeitas às consequências daí decorrentes. (Cf. MARTINS, Fran. Curso de direito comercial. Rio de Janeiro: Forense, 2000)

Por outro lado, diversos autores, como João Eunápio Borges e Pedro Barbosa Pereira, rejeitam tais distinções, afirmando que mancam finalidade prática e o uso das duas expressões no mesmo sentido é 
apenas no mundo dos fatos. São entes que atuam exteriorizando uma aparente regularidade, que não possuem.

Reconhecendo essa realidade, o artigo 305 do Código Civil trazia um rol não taxativo de atos cuja prática fazia presumir a existência de sociedade ${ }^{73}$. Contudo, nem a sociedade de fato, nem a sociedade irregular estavam sujeitas a maior regulamentação legal, de modo que seu regramento se constituiu, em grande parte, de construção doutrinária.

O Código Civil abarcou tanto as sociedades irregulares e as sociedades de fato, seja qual for o tipo societário adotado ${ }^{74}$, sob o título de "sociedade em comum",75, disciplinada nos Artigos 986 a 990, sob a regência da Sociedade Não Personificada.

consagrado em diversos países. (Cf. BORGES, João Eunápio. Curso de direito comercial terrestre. Rio de Janeiro: Forense, 1964. p. 255 e PEREIRA, Pedro Barbosa. Curso de direito comercial - sociedades comerciais e títulos de crédito. São Paulo: RT, 1969. v. 2. p. 18)

73 Negociação promíscua e comum; aquisição, alheação, permutação, ou pagamento comum; se um dos associados se confessa sócio, e os outros o não contradizem por uma forma pública; se duas ou mais pessoas propõem um administrador ou gerente comum; a dissolução da associação como sociedade; o emprego do pronome nós ou nosso nas cartas de correspondência, livros, fatura, contas e mais papéis comerciais; o fato de receber ou responder cartas endereçadas ao nome ou firma social; o uso de marca comum nas fazendas ou volumes; o uso de nome com a adição - e companhia.

Apesar de revogado o artigo, suas disposições são ainda hoje invocadas para caracterizar as sociedades em comum.

74 À exceção das sociedades anônimas em constituição, que estão sujeitas a regime legal próprio. Em razão do princípio da publicidade inerente a esse tipo societário, é necessária, além da inscrição de seus atos constitutivos, a publicação destes atos, nos termos do Art. 94 da Lei no 6.404/76. Até que se concluam os atos constitutivos, os fundadores atuam em nome pessoal e no interesse da sociedade em formação.

${ }^{75}$ Enunciado $\mathrm{n}^{\mathrm{o}} 58$ da Jornada de Direito Civil promovida pelo Centro de Estudos Jurídicos do Conselho da Justiça Federal: “Art. 986 e seguintes: a sociedade em comum compreende as figuras da sociedade de fato e da irregular."

A posição é aceita por boa parte da doutrina. (cf. FRANCO, Vera Helena de Mello. Direito empresarial. $3^{\mathrm{a}}$ ed. rev, atual. e ampl. São Paulo: RT, 2009. v. 1. pp. 173-174)

Há, contudo, quem discorde desse posicionamento, em especial com relação à irregularidade superveniente. (cf. FÉRES, Marcelo Andrade. "A depuração da sociedade em comum: primeiras considerações sobre o regime jurídico das sociedades contratuais em formação”. In: Repertório de Jurisprudência IOB, n. 19, v. 3, 2004. p. 569 e KALANSKY, Daniel. “A sociedade em comum: um novo tipo societário?”. In: FRANÇA, Erasmo Valladão Azevedo e Novaes (org.). Direito societário contemporâneo I. São Paulo: Quartier Latin, 2009. p. 516)

Isso porque a sociedade em comum é sociedade não personificada, ou seja, não possui personalidade jurídica, em razão da falta de registro próprio. No caso da irregularidade superveniente, que se dá, por exemplo, nas hipóteses de falta de arquivamento de alterações de contrato social, não se poderia afirmar ter a sociedade se transformado em "sociedade em comum” em razão da irregularidade, vez que não perde a sociedade o caráter de pessoa jurídica.

De qualquer modo, entendemos que a sociedade eivada de irregularidade superveniente seria equiparada, para fins de responsabilização, à sociedade comum, sujeitando-se ás normas e condições a ela pertinentes. 
Dessa forma, à exceção das S.A. em constituição ${ }^{76}$, as sociedades, enquanto não tiverem arquivado seus atos constitutivos no registro competente ${ }^{77}$, não adquirem personalidade própria, sendo regidas pelas regras da sociedade em comum e, subsidiariamente, pelas regras da sociedade simples. Têm, no entanto, sua existência, validade e eficácia reconhecidas pelo legislador.

A falta do registro válido acarreta às sociedades em comum a ausência dos benefícios concedidos pela lei às sociedades personalizadas, tais como a possibilidade de recuperação judicial e o pedido de autofalência, a legitimação para requerer falência de terceiros, a proteção ao nome empresarial e à marca, entre outros ${ }^{78}$. Ressalte-se, contudo, que, se empresárias, estão as sociedades em comum sujeitas ao requerimento de falência por seus credores.

\subsubsection{Sociedades em conta de participação}

Na sociedade em conta de participação o sócio denominado ostensivo é que exerce a atividade constitutiva do objeto social, em seu nome e sob sua exclusiva responsabilidade. É ele - e somente ele - que aparece perante o mercado. Há, também, o sócio participante (dito oculto no regramento anterior), que apenas contribui com o capital e participa nos resultados, sem ingerência na sociedade ou em suas atividades.

As sociedades em conta de participação, cada vez mais difundidas como forma de estruturação de negócios, não possuem personalidade jurídica por expressa determinação legal.

\footnotetext{
${ }^{76}$ Vide NR 74 acima.

${ }^{77}$ Cumpre ressaltar que não apenas a ausência do registro leva à falta de personalização, mas também o registro efetuado em desacordo com as normas legais, e que, portanto, são inválidos, salvo os casos de registros efetuados de boa-fé.

Nesse sentido, Enunciado n 209 da III Jornada de Direito Civil promovida pelo Centro de Estudos Jurídicos do Conselho da Justiça Federal: “Arts. 985, 986 e 1.150: o art. 986 deve ser interpretado em sintonia com os arts. 985 e 1.150, de modo a ser considerada em comum a sociedade que não tenha seu ato constitutivo inscrito no registro próprio ou em desacordo com as normas legais previstas para esse registro (art. 1.150), ressalvadas as hipóteses de registros efetuados de boa-fé."

78 CANAVEZ, Luciana Lopes. "A sociedade em comum como modelo de sociedade empresária no Novo Código Civil”. In: Revista Jurídica da Universidade de Franca, ano 6, n. 11, 2003. p. 131.
} 
Sua constituição independe de qualquer formalidade, sendo possível prová-la por qualquer meio. O contrato social produz efeitos somente entre os sócios e seu arquivamento perante o registro próprio, se houver, não confere à sociedade em conta de participação personalidade jurídica $^{79}$.

Trata-se, pois, de exceção aos Artigos 45 e 985 do Código Civil.

\subsection{Efeitos da personalização}

Os principais reflexos do reconhecimento da pessoa jurídica como sujeito de direitos e obrigações, segundo Pontes de $\operatorname{Miranda}^{80}$, são o reconhecimento da capacidade para exercício de direitos previstos no direto positivo, compatíveis com o suporte fático, e a distinção entre o patrimônio da pessoa jurídica e dos membros que a compõem ou dirigem.

Com base na atribuição de personalidade pelo ordenamento jurídico, a partir da qual o sujeito disporá de capacidade (de direito) e será sujeito de direitos e obrigações, a pessoa jurídica poderá manifestar o seu interesse de agir, praticar atos jurídicos, obrigar-se perante terceiros e exercer os seus direitos. A pessoa dotada de personalidade jurídica também possui faculdades que lhe são inerentes, isto é, a capacidade de agir (capacidade de fato), a aptidão para exercer direitos e contrair obrigações, manifestando a sua própria vontade, com reconhecimento jurídico ${ }^{81}$.

Depreende-se, então, que os direitos inerentes à personalidade são estruturados a partir de dois planos: aquele de caráter substancial, com o preenchimento das condições gerais estabelecidas pela legislação para a pessoa e a sua capacidade de direito; e aquele relacionado aos requisitos formais estabelecidos pelo Estado para o reconhecimento da personalidade e exercício da capacidade de fato. Dessa forma,

\footnotetext{
${ }^{79}$ Código Civil, Art. 993. O contrato social produz efeito somente entre os sócios, e a eventual inscrição de seu instrumento em qualquer registro não confere personalidade jurídica à sociedade.

${ }^{80}$ PONTES DE MIRANDA, Francisco Cavalcanti. Tratado de direito privado. Rio de Janeiro: Borsoi, 1954. t. I, v. 1. p. 288.

${ }^{81}$ BEVILÁQUA, Clóvis. Código civil dos Estados Unidos do Brasil - comentado. $4^{\mathrm{a}}$ ed. Rio de Janeiro: Francisco Alves, 1993. v. 1. p. 165.
} 
conclui-se que um dos reflexos da personalização é o reconhecimento da personalidade e da capacidade para agir, na forma disposta pela lei.

Um segundo reflexo da personalização é a separação de vontades entre o ente personalizado e seus sócios, associados, fundadores e administradores. A pessoa jurídica é um ente autônomo. Isso é resultado da capacidade da sociedade, que, personalizada, passa a ter vontade e interesses próprios, devido ao fato de o legislador brasileiro ter abraçado o princípio da criação personificante, ou seja, uma vez criada a entidade e atendidos os requisitos legais, a mesma personifica-se ${ }^{82}$.

Por fim, um último efeito da personalização é a vinculação do patrimônio, de modo que a pessoa jurídica passa a ser proprietária do patrimônio que a ela foi destinado, respondendo pelas dívidas e obrigações sociais ${ }^{83}$. Isso delimita a esfera de responsabilidade dos sócios, efeito esse especialmente relevante, como se verá adiante.

${ }^{82}$ PONTES DE MIRANDA, Francisco Cavalcanti. Tratado de direito privado. Rio de Janeiro: Borsoi, 1954. t. I, v. 1. p. 282.

${ }^{83}$ PONTES DE MIRANDA, Francisco Cavalcanti. Tratado de direito privado. Rio de Janeiro: Borsoi, 1954. t. I, v. 1. p. 339. 


\section{A PROBLEMÁTICA DA LIMITAÇÃO DE RESPONSABILIDADE DO EMPRESÁRIO INDIVIDUAL}

A questão da limitação da responsabilidade do empresário individual sempre foi objeto de polêmica. Todavia, é cada vez mais comum a adoção pelos diversos ordenamentos jurídicos da responsabilidade limitada relativamente àqueles que exercem o comércio de forma individual, seja por meio do reconhecimento da limitação em formas não societárias ${ }^{84}$, seja pela instituição das sociedades unipessoais ${ }^{85}$.

A limitação de responsabilidade do empresário individual consiste na última fase de evolução da noção jurídica de responsabilidade ${ }^{86}$.

No passado, o devedor respondia com a própria vida. Desse conceito evoluiu-se para a restrição da liberdade e, em seguida, em um salto importantíssimo, para a responsabilização exclusiva com o patrimônio do devedor ${ }^{87}$.

Ressalte-se que, no direito brasileiro, desde a Constituição Federal de 1934 está prevista a impossibilidade de prisão civil por dívidas, atualmente constante do inciso LXVII do Artigo $5^{\circ}$ da Constituição Federal de 1988, excetuando-se de tal restrição o inadimplemento voluntário e inescusável de obrigações alimentícias e a infidelidade do depositário $^{88}$.

${ }^{84}$ Como é o caso do Paraguai (Ley no ${ }^{\circ} .034$, de 16.12.1983) e Portugal (Decreto Lei no $248 / 86$ ).

${ }^{85}$ Como quase todos os países da União Europeia, Suíça, diversos estados dos Estados Unidos da América, Japão, África do Sul, Costa Rica, Peru, Chile, entre outros.

${ }^{86}$ COSTA, Ricardo Alberto Santos. Sociedade por quotas unipessoal no direito português. Coimbra: Almedina, 2002. p. 127.

${ }^{87}$ A Lex Poetelia Papiria (que data de 326 a.C., segundo Titus Livius, e cujo nome deriva do cônsul Gaius Poetelius Libo Visolus), extinguiu o instituto do nexum, afastando a possibilidade de execução sobre a pessoa do inadimplente e determinando a orientação das ações do credor contra o patrimônio do devedor.

${ }^{88}$ Esta segunda exceção é hoje inaplicável, segundo entendimento atual do Plenário do Supremo Tribunal Federal:

"PRISÃO CIVIL DO DEPOSITÁRIO INFIEL EM FACE DOS TRATADOS INTERNACIONAIS DE DIREITOS HUMANOS. INTERPRETAÇÃO DA PARTE FINAL DO INCISO LXVII DO ART. $5^{\circ}$ DA CONSTITUIÇÃO BRASILEIRA DE 1988. POSIÇÃO HIERÁRQUICO-NORMATIVA DOS TRATADOS INTERNACIONAIS DE DIREITOS HUMANOS NO ORDENAMENTO JURÍDICO BRASILEIRO. Desde a adesão do Brasil, sem qualquer reserva, ao Pacto Internacional dos Direitos Civis e Políticos (art. 11) e à Convenção Americana sobre Direitos Humanos - Pacto de San José da Costa Rica (art. $7^{\circ}, \S 7$ ), ambos no ano de 1992, não há mais base legal para prisão civil do depositário infiel, pois o caráter especial desses diplomas internacionais sobre direitos humanos lhes reserva lugar específico no ordenamento jurídico, estando abaixo da Constituição, porém acima da legislação interna. O status normativo supralegal dos tratados internacionais de direitos humanos subscritos pelo Brasil torna 
Com o surgimento e evolução do conceito de pessoa jurídica, passou-se a admitir a responsabilização do ente coletivo de forma autônoma e destacada do patrimônio de seus integrantes. Finalmente, nos dias atuais, observa-se um movimento amplo e global no sentido da adoção da limitação da responsabilidade do empresário individual.

Isso porque se a lei reconhece a existência de um interesse social na limitação do risco dos empreendimentos coletivos, esse mesmo interesse se manifesta relativamente aos empresários individuais, e explica o desejo de uma solução adequada para delimitar o risco e a responsabilidade do empresário singular ${ }^{89}$.

No Brasil, a figura do empresário individual não está sujeita à limitação de responsabilidade, diferentemente do regime mais comum aplicável à empresa coletiva, o que torna a atividade do empresário singular um risco superior aos parâmetros da razoabilidade.

inaplicável a legislação infraconstitucional com ele conflitante, seja ela anterior ou posterior ao ato de adesão. Assim ocorreu com o art. 1.287 do Código Civil de 1916 e com o Decreto-Lei n ${ }^{\circ}$ 911/69, assim como em relação ao art. 652 do Novo Código Civil (Lei n 10.406/2002).

ALIENAÇÃO FIDUCIÁRIA EM GARANTIA. DECRETO-LEI N ${ }^{\circ}$ 911/69. EQUIPARAÇÃO DO DEVEDOR-FIDUCIANTE AO DEPOSITÁRIO. PRISÃO CIVIL DO DEVEDOR- FIDUCIANTE EM FACE DO PRINCÍPIO DA PROPORCIONALIDADE. A prisão civil do devedor-fiduciante no âmbito do contrato de alienação fiduciária em garantia viola o princípio da proporcionalidade, visto que: a) o ordenamento jurídico prevê outros meios processuais-executórios postos à disposição do credor-fiduciário para a garantia do crédito, de forma que a prisão civil, como medida extrema de coerção do devedor inadimplente, não passa no exame da proporcionalidade como proibição de excesso, em sua tríplice configuração: adequação, necessidade e proporcionalidade em sentido estrito; e b) o Decreto-Lei $\mathrm{n}^{\circ}$ 911/69, ao instituir uma ficção jurídica, equiparando o devedor-fiduciante ao depositário, para todos os efeitos previstos nas leis civis e penais, criou uma figura atípica de depósito, transbordando os limites do conteúdo semântico da expressão "depositário infiel" insculpida no art. 52, inciso LXVII, da Constituição e, dessa forma, desfigurando o instituto do depósito em sua conformação constitucional, o que perfaz a violação ao princípio da reserva legal proporcional." (STF, RE 349.703/RS, Rel. Min. Gilmar Mendes, Tribunal Pleno, d.j. 03.12.2008)

"EMENTA: PRISÃO CIVIL. Depósito. Depositário infiel. Alienação fiduciária. Decretação da medida coercitiva. Inadmissibilidade absoluta. Insubsistência da previsão constitucional e das normas subalternas. Interpretação do art. $5^{\circ}$, inc. LXVII e $\S \S 1^{\circ}, 2^{\circ}$ e $3^{\circ}$, da CF, à luz do art. $7^{\circ}, \S 7$, da Convenção Americana de Direitos Humanos (Pacto de San José da Costa Rica). Recurso improvido. Julgamento conjunto do RE $\mathrm{n}^{\circ} 349.703$ e dos $\mathrm{HCs} n^{\circ} 87.585$ e $\mathrm{n}^{\circ}$ 92.566. É ilícita a prisão civil de depositário infiel, qualquer que seja a modalidade do depósito." (STF, RE 466.343/SP, Rel. Min. Cezar Peluso, Tribunal Pleno, d.j. 03.12.2008)

"DEPOSITÁRIO INFIEL - PRISÃO. A subscrição pelo Brasil do Pacto de São José da Costa Rica, limitando a prisão civil por dívida ao descumprimento inescusável de prestação alimentícia, implicou a derrogação das normas estritamente legais referentes à prisão do depositário infiel.” (STF, HC 87.585/TO, Rel. Min. Marco Aurélio, Tribunal Pleno, d.j. 03.12.2008)

${ }^{89}$ MARCONDES MACHADO, Sylvio. Limitação de responsabilidade de comerciante individual. São Paulo: Max Limonad, 1956. p. 47. 
A relativamente recente regulação da legislação civil e empresarial pátrias, consubstanciadas no Código Civil de 2002, não trouxe qualquer novidade nesse setor, deixando, nos dizeres de Vera Helena de Mello Franco, "passar em branco a possibilidade de introdução da sociedade limitada unipessoal em descompasso flagrante com as leis modernas, sem explicar o porquê da postura rançosa" $"$.

\subsection{O empresário individual}

Os empresários individuais, que assumem pessoalmente os riscos da atividade empresarial, constituem grande parcela das micro e pequenas empresas do país. De acordo com as estatísticas do Departamento Nacional do Registro do Comércio $(\mathrm{DNRC})^{91}$, somente no ano de 2005 foram registradas, nas Juntas Comerciais, 240.306 novas firmas individuais, contra 246.726 sociedades limitadas.

Mesmo matriculada no registro do comércio competente, a empresa individual não possui personalidade jurídica distinta da pessoa física que a criou. Desse modo, não há diferenciação patrimonial entre os bens pessoais do sócio e os bens destinados ao exercício da atividade empresarial. Isso significa que todos os bens do sócio $^{92}$ respondem por dívidas contraídas pela empresa, da mesma forma que todos os bens afetados ao exercício da empresa respondem por débitos eventualmente contraídos em caráter particular pelo sócio.

A limitação da responsabilidade é importante redutor dos riscos da atividade, incentivando seu desenvolvimento. Por outro lado, trata-se de relevante garantia aos credores empresariais, que não concorrem com os credores pessoais do sócio pelo mesmo patrimônio.

\footnotetext{
90 FRANCO, Vera Helena de Mello. "O triste fim das sociedades limitadas no novo Código Civil". In: Revista de Direito Mercantil Industrial, Econômico e Financeiro, v. 123, 2001. p. 84.

${ }^{91}$ Fonte:ihttp://Www.dnrc.gov.bri, acesso em 23/10/2009.

92 Com exceção dos bens absolutamente impenhoráveis, cf. art. 649 do Código de Processo Civil e Lei $\mathrm{n}^{\circ} 8.009 / 90$.
} 
Nada obstante, inexiste no Brasil o reconhecimento legislativo de qualquer forma de limitação de responsabilidade do empresário individual ${ }^{93}$.

O não reconhecimento da limitação de responsabilidade para o empresário individual no Brasil é atitude retrógrada, injustificada, inútil e predatória. Retrógrada, porque vai à contramão das tendências mundiais; injustificada, porque, como se verá, não existem empecilhos legais ou sequer conceituais à sua adoção; inútil, porque incentiva o uso de estruturas alternativas para viabilizar a criação do negócio; e predatória, porque muitas vezes desestimula a criação de pequenos negócios ou sua formalização, prejudicando o país como um todo, dos pontos de vista econômico e social.

\subsection{Origem do preconceito relativo à limitação de responsabilidade do empresário individual}

Os preconceitos teóricos relativos à problemática da limitação de responsabilidade do empresário individual têm origem no século $\mathrm{XIX}^{94}$, quando surgem questões polêmicas ligadas à própria concepção de pessoa jurídica, como a possibilidade de personificação (ou seja, criação de novo centro de imputação de direitos e deveres) de um ente não coletivo e possibilidade de separação patrimonial para o exercício de uma atividade.

O individualismo reinante e a forte concepção de unidade do patrimônio, que seria uma "emanação da personalidade" 95 e, portanto, uno e indivisível, dificultam a aceitação da separação patrimonial. Ademais, por visualizarem a vontade da pessoa coletiva conformada pela pluralidade de seus componentes, a maioria das teorias a respeito

93 Salvo no caso da limitação de responsabilidade idealizada para grupos (subsidiária integral) e a possibilidade de unipessoalidade temporária, que não são objeto do presente trabalho, mas serão brevemente analisados posteriormente, nos itens 7.1 e 7.2.

94 Até o século XIX, praticamente não havia discussões quanto à definição de sociedade, em razão da forte influência do contratualismo reinante e das concepções romanistas de sociedade. A discussão prática da unipessoalidade se dava quase que exclusivamente com relação à chamada corporation sole, instituto amplamente utilizado pela igreja católica para manter e administrar seus bens, que consiste em uma única pessoa, ou os sucessores de sua função (em geral outra pessoa com o mesmo título), a quem a lei atribui certas capacidades jurídicas e privilégios, em especial a perpetuidade, que não poderia existir para as pessoas naturais. Desse modo, o rei da Inglaterra é uma corporation sole, assim como o bispo, alguns cônegos em relação aos seus diversos cabidos, os párocos e vigários.

95 BRUSCATO, Wilges Ariana. Empresário individual de responsabilidade limitada São Paulo: Quartier Latin, 2005. p. 164. 
da pessoa jurídica acaba por rejeitar, à primeira vista ${ }^{96}$, a limitação da responsabilidade do empresário individual.

No final do século XIX, na Inglaterra, levantou-se a questão da limitação da responsabilidade negocial a um determinado montante, alegando-se ser inadequado que um país de alta civilização fizesse responsável um homem além do limite que ele tenha estipulado e que tenha sido aceito pelas outras partes com quem ele negocia. Com o início, na Alemanha, das discussões sobre a lei das sociedades de responsabilidade limitada (Gesellschaft mit beschränkter Haftung, ou GmbH.), os juristas suíços e austríacos também passaram a abordar sua aplicação aos comerciantes individuais, chamando-se atenção, nesse sentido, para os estudos de Pisko e a apresentação, em 1910, de um projeto de lei pioneiro da regulamentação do instituto, que inspirou a adoção da empresa individual de responsabilidade limitada pelo principado de Liechtenstein ${ }^{97}$.

Todavia, é a partir da segunda metade do século XX, em razão das melhorias econômicas e a consequente ampliação da demanda de crédito, que a regra da unidade patrimonial perde o caráter absoluto, abrindo espaço para ampla admissão da separação patrimonial e limitação de responsabilidade.

\footnotetext{
${ }^{96}$ No entanto, como bem observado por Calixto Salomão Filho, em sua obra sobre as sociedades unipessoais, essas teorias acabam, cada uma a sua maneira, justamente por contribuir para a estruturação da teoria da limitação de responsabilidade do comerciante individual.
}

Com Savigny a questão da sociedade com um só sócio vem à tona, pois, apesar de negar a possibilidade de criação de sociedades unipessoais, por entender que eram necessários ao menos três componentes para constituir uma sociedade, Savigny corroborava com a possibilidade de permanência da sociedade reduzida à unipessoalidade, o que deu ensejo ao seu reconhecimento na legislação germânica.

A própria a teoria organicista de Gierke, que apregoa que a pluralidade de componentes é que confere vontade própria à sociedade (o mesmo não ocorrendo nas associações e fundações, que têm vinculação ao objeto) e que a redução a um só sócio daria ensejo à extinção da pessoa jurídica, por não mais existir uma vontade comum distinta da de seu sócio, contribui, de sua maneira, à teoria da limitação de responsabilidade do comerciante individual, por chamar atenção para o perfil interno das sociedades.

(Cf. SALOMÃO FILHO, Calixto. A sociedade unipessoal. São Paulo: Malheiros, 1995. pp. 15 e ss.)

97 MARCONDES MACHADO, Sylvio. Limitação de responsabilidade de comerciante individual. São Paulo: Max Limonad, 1956. pp. 48 e ss.

Para Pisko, a justificação da responsabilidade limitada está na necessidade de limitar o risco próprio da exploração de uma empresa. A correlação entre sociedade e responsabilidade limitada não é uma necessidade absoluta, atribuindo o legislador a limitação às sociedades em razão destas oferecerem um substrato apropriado à existência de uma pessoa jurídica, expressiva da situação econômica da responsabilidade limitada. O que importa para fins de atribuição de limitação de responsabilidade é a existência de um patrimônio responsável bem delimitado (ou Sondergut). Bastaria que se configurasse uma situação semelhante na empresa individual para que se lhe possa atribuir a limitação dos riscos. 


\subsection{As sociedades fictícias como forma de limitação de responsabilidade}

Fato recorrente em qualquer ordenamento jurídico em que se preveja limitação de riscos exclusivamente para entes coletivos é a criação de sociedades de favor, em que o empresário individual se vale do auxílio e concordância de outras pessoas para constituir, assim, sociedade e aproveitar-se dos benefícios da responsabilidade limitada no exercício de suas atividades.

A fim de obter a almejada limitação de responsabilidade, muitos empresários se voltam para a formação de sociedades fictícias (società di comodo), quase sempre estruturadas na forma de sociedades limitadas em que um dos sócios detém a grande maioria do capital social e um "testa-de-ferro", também conhecido na doutrina como homem-de-palha ou strawman - em geral um familiar ou pessoa próxima que não terá qualquer participação nos desígnios da sociedade - completa o quadro social, apenas com a intenção de atingir a pluralidade exigida pela lei para limitação da responsabilidade.

Como afirmam Tullio Ascarelli e Ferrer Correia, a limitação de responsabilidade do empresário individual em si não é resultado proibido pelo legislador; apenas carece de forma jurídica que possibilite obter tal resultado ${ }^{98}$. Assim, seria legítima a utilização indireta de outros instrumentos admitidos em direito para alcançar o resultado desejado.

Contudo, existe alguma discussão doutrinária quanto à validade ou não da constituição desse tipo de sociedade, debatendo-se quanto ao fato de se tratar de simulação ou mero negócio indireto.

\subsubsection{Simulação e negócio indireto}

A distinção entre simulação e negócio indireto foi magistralmente tratada por Tullio Ascarelli. Ele ensina que há negócio indireto "sempre que as partes recorrem,

\footnotetext{
98 ASCARELLI, Tullio. "O negócio indireto". In: Problemas das sociedades anônimas e direito comparado. Campinas: Bookseller, 2001. p. 217 e FERRER CORREIA, António de Arruda. Sociedades fictícias e unipessoais. Coimbra: Atlântida, 1948. p. 256.
} 
no caso concreto, a um negócio determinado visando a alcançar através dele, consciente e consensualmente, finalidades diversas das que, em princípio, lhe são típicas." 99

Na simulação, por outro lado ${ }^{100}$,

"o objetivo da vontade real das partes está em contraste com o que decorre da declaração delas; a realização do primeiro exclui a do segundo e, por isso, é tarefa do direito estabelecer, seja nas relações entre as partes, seja quanto aos terceiros, qual deva prevalecer, se a vontade real, se a declaração aparente."

Assim, na simulação as partes desejam fim diverso do declarado ${ }^{101}$, enquanto no negócio indireto não há discrepância entre a vontade declarada e a vontade real dos envolvidos. No negócio indireto, as partes querem exatamente o negócio declarado; no entanto, desejam alcançar uma finalidade que não é típica no negócio adotado.

Considerando-se que, no Brasil, a constituição de sociedades unipessoais só é permitida na hipótese da subsidiária integral, buscou-se circundar essa proibição utilizando-se um sócio meramente figurativo com participação simbólica na sociedade, para adequar-se ao critério de pluralidade de associados.

Neste caso, devemos discordar da posição de Ferrer Correia ${ }^{102}$, que argumenta que, embora o sócio de complacência almeje efetivamente a separação patrimonial advinda da constituição da sociedade, faltar-lhe-ia a real intenção de constituir-se sócio da empresa e assumir os direitos e obrigações daí advindos.

Entendemos, de forma diversa, que na sociedade assim constituída, as partes querem, efetivamente, a constituição da sociedade e o negócio aparece perante terceiros exatamente como o que foi celebrado, não havendo a necessária discrepância entre a realidade e a aparência que caracteriza a simulação.

\footnotetext{
99 ASCARELLI, Tullio. "O negócio indireto”. In: Problemas das sociedades anônimas e direito comparado. Campinas: Bookseller, 2001. p. 156.

${ }^{100}$ ASCARELLI, Tullio. "O negócio indireto". In: Problemas das sociedades anônimas e direito comparado. Campinas: Bookseller, 2001. p. 179.

${ }^{101} \mathrm{Ou}$ até mesmo fim nenhum, como no caso da simulação absoluta.

${ }^{102}$ FERRER CORREIA, António de Arruda. Sociedades fictícias e unipessoais. Coimbra: Atlântida, 1948. p. 161.
} 
A vontade declarada é equivalente à vontade real, pois o sócio, mesmo que minoritário, é sócio efetivo e não se pode dizer que tenha prestado declaração diversa de seu intento de ser efetivamente sócio e assumir as obrigações daí decorrentes. Desse modo, sendo o objeto lícito, as partes capazes e satisfeitas as formalidades legais de constituição e registro, o negócio é perfeitamente válido ${ }^{103}$.

Não há que se falar, também, em lesão a credores, quer conheçam ou não aqueles o caráter de favor da sociedade. Isso porque quando negociam com a sociedade o fazem com ente autônomo, cientes do risco a que estão sujeitos em razão do capital e patrimônio sociais e não podem, pois, contar com outros bens para sua garantia.

Nada obstante se defenda a validade da sociedade em que apenas uma das partes efetivamente contribui para a consecução plena do negócio, não se pode afirmar que seja situação desejável, tanto em razão da necessidade de recurso a ficções para sua justificativa, quanto pelos seus efeitos potencialmente nocivos.

Aliás, o próprio desenvolvimento das controvérsias a respeito das sociedades fictícias demonstra, como coloca Sylvio Marcondes, a importância do problema gerador do fenômeno: a responsabilidade limitada no exercício do comércio singular ${ }^{104}$.

\footnotetext{
${ }^{103}$ Calixto Salomão Filho critica as premissas desse raciocínio, defendendo que não se pode aplicar um raciocínio civilístico às sociedades sem as devidas adaptações.

A simulação é aplicável a atos, e não a uma atividade; e suas consequências jurídicas se coadunam apenas com a disciplina dos atos. Uma atividade não pode ser declarada nula ou anulada, pois os muitos efeitos que produz perante terceiros não podem ser eliminados.

Fala-se em atividade irregular, e não em atividade nula, pois, em linha com a ideia institucionalista de preservação da empresa, a disciplina dos atos sociais não se deve dirigir a eliminar a sociedade, e sim a eliminar a lesão que pode ser provocada pelo ato.

Desse modo, não existiria sociedade simulada, mas sim a caracterização da simulação de um ato específico. O remédio para tanto seria aplicar as consequências respectivas à irregularidade na atividade social ou aplicar a teoria da desconsideração da personalidade jurídica, quando for o caso.

(Cf. SALOMÃO FILHO, Calixto. "Sociedade simulada". In: Revista de Direito Mercantil Industrial, Econômico e Financeiro, v. 105, 1997. pp. 72-73)

${ }^{104}$ MARCONDES MACHADO, Sylvio. Limitação de responsabilidade de comerciante individual. São Paulo: Max Limonad, 1956. p. 47.
} 


\subsubsection{Os efeitos da ficção}

A responsabilização ilimitada do empresário individual leva ao incentivo de ficções, mediante a utilização de sócios de favor para a constituição de verdadeiras sociedades unipessoais escamoteadas na forma de sociedades limitadas de aparência.

Especula-se que, no Brasil, mais de $80 \%$ das sociedades limitadas, sejam, em verdade, sociedades unipessoais travestidas, em que o(s) sócio(s) minoritário(s) tem(têm) participação diminuta no capital social e não contribui(em) para a administração da empresa.

Ocorre que tais sócios fictícios acabam, vez por outra, por serem pessoalmente responsabilizados em razão de irregularidades praticadas pela sociedade, atingidos pela desconsideração da personalidade e - o que é mais grave - nem sempre a proporção de sua participação no capital é respeitada para fins de quantificação da responsabilização pessoal ${ }^{105}$.

${ }^{105}$ Nesse sentido:

"PENHORA EM CONTA BANCÁRIA - EXECUÇÃO DEFINITIVA - SÓCIO MINORITÁRIO VALIDADE. Irrelevante a condição da agravante de sócia minoritária e sem poderes de administração, tendo em vista a natureza alimentar do crédito trabalhista, que, por isso, não pode ficar indefinidamente à espera de ver adimplido os seus créditos apenas pela devedora principal. Ademais, a penhora sobre numerário existente em conta bancária encontra respaldo na gradação do art. 655 do CPC, cuja ordem preferencial visa garantir a rápida e completa satisfação do credor, o que se revela ainda mais pertinente em face do mencionado caráter alimentar do débito executado (Inteligência do art. 646 do CPC e da Súmula 417, I, do TST). Agravo desprovido." (TRT/MG, AP 00206-2005-025-03-00-2, Rel. Des. Deoclecia Amorelli Dias, 10a Turma, d.j. 11.02.2009)

“AGRAVO DE PETIÇÃO. DESCONSIDERAÇÃO DA PERSONALIDADE JURIDICA. SÓCIO MINORITÁRIO. Já é pacífico, na doutrina e na jurisprudência, o entendimento pelo qual, à ausência de bens da empresa devedora, suficientes para a garantia da execução, responderão os bens patrimoniais de seus próprios sócios pelas dívidas por ela contraídas, ainda que sejam detentores minoritários do capital social, não possuam poderes de gestão e administração e não tenham participado da fase processual de conhecimento. Esse entendimento, amplamente aceito na esfera do Direito do Trabalho e aplicado na sistemática processual trabalhista, decorre da teoria da desconsideração da personalidade jurídica, consagrada no art. 28 da Lei $n^{o}$. 8.078/90 (Código de Defesa do Consumidor), sendo que, nesta Especializada, a sua aplicação ainda decorre de princípios protetivos próprios, que visam a garantir, com a maior celeridade possível, o pagamento da verba alimentar ao trabalhador hipossuficiente" (TRT/MG, AP 00794-1996-018-03-00-4, Rel. Des. Márcio Ribeiro do Valle, $8^{\mathrm{a}}$ Turma, d.j. 30.08.2008)

"SÓCIO MINORITÁRIO DE SOCIEDADE LIMITADA. COTA-PARTE IRRISÓRIA. RESPONSABILIDADE PLENA PELAS DÍVIDAS TRABALHISTAS. A desconsideração da pessoa jurídica operada pela CLT via personificação da empresa (art. $2^{\circ}$ e seus oo, art. $10^{\circ}$ e art. 448 , da $C L T)$, submete inclusive o sócio minoritário de sociedade limitada. A única condição objetiva para essa responsabilização é o inadimplemento de dívidas trabalhistas. A proporção irrisória da cotaparte do sócio não é empecilho e, muitas vezes, figura para iludir os credores, ocultando-se sob o véu da pessoa jurídica, e dentro dos muros da responsabilidade limitada." (TRT/PR, AP 16903-2001012-09-00-2, Rel. J. Rosemarie Diedrichs Pimpão, Sessão Especializada, d.j. 21.10.2005) 
Demais disso, a discricionariedade de interpretação do magistrado pode, por vezes, levar a situações de não reconhecimento da sociedade de favor como válida ${ }^{106}$, ocasionando a responsabilização ilimitada do "sócio único" pelas dívidas sociais ab initio $^{107}$.

"DESCONSIDERAÇÃO DA PERSONALIDADE JURÍDICA - INEXISTÊNCIA DE BEM DA SOCIEDADE - DÉBITO TRABALHISTA -CABIMENTO. A teoria da desconsideração da personalidade jurídica é aplicável para garantir o cumprimento de decisão trabalhista quando inexistem bens da empresa executada a fim de que se preserve o direito do empregado que contribuiu para o desenvolvimento da atividade empresarial.

\section{VOTO:}

(...)

MÉRITO

\section{DA ILEGITIMIDADE DE PARTE}

Os agravantes aduzem a ilegitimidade de parte sob o argumento de não foram condenados a pagar o crédito trabalhista que ora se executa, mas sim a firma Almeida e Silva Construções Ltda.

Acrescentam que, conforme o contrato social inserto aos autos, o sócio majoritário da citada empresa é o Sr. Arnaldo Medeiros da Silva, como 85\% (oitenta e cinco por cento) do capital social, que faleceu em 27/09/1996, enquanto eles se apresentam como sócio minoritário na seguinte proporção: João Batista de Almeida com 14\% e Antônio Gilberto Almeida com 1\%.

Assim, defendem que a presente execução deve ser dirigida para a firma condenada identificada na ata de instrução e julgamento ou para o espólio do sócio majoritário.

Os argumentos aduzidos pelos agravantes não prosperam.

In casu, houve a desconsideração da personalidade jurídica da executada, fl. 145, tendo a decisão de embargos à execução, fls. 228/232, pronunciado pela correta inclusão, no pólo passivo da demanda, dos sócios minoritários sob o argumento de que a divisão de cotas não se sobrepãe à responsabilidade por crédito trabalhista, transcrevendo algumas ementas deste Regional.

A desconsideração da personalidade jurídica, amplamente adotada pela Justiça do Trabalho, objetiva prover o Juízo de meios que possibilitem o pagamento dos débitos judiciais, atingindo o patrimônio dos sócios que, de alguma forma, se beneficiaram do trabalho do credor. Tal instituto indica que o princípio da separação patrimonial e o da limitação da responsabilidade dos sócios não são absolutos, de forma que os sócios e ex-sócios podem responder com o próprio patrimônio, em situações como inexistência de bens da empresa executada capazes de garantir o crédito objeto de execução." (TRT/SE, Ag.Pet. 00011-2007-920-20-00-3, Rel. J. Jorge Antônio Andrade Cardoso, d.j.11.04.2007) (Grifamos)

${ }^{106}$ Lamartine Corrêa de Oliveira nos traz exemplos de equiparação prática da sociedade em que um dos sócios detém mais de $99 \%$ do capital a sociedade unipessoal na jurisprudência alemã.

Cf. OLIVEIRA, José Lamartine Corrêa de. A dupla crise da pessoa jurídica. São Paulo: Saraiva, 1979. p. 436.

${ }^{107}$ Nesse sentido:

"Agravo de Instrumento. Cumprimento de sentença condenatória. Deferimento de penhora "on line" de numerário existente em contas bancárias/aplicações do devedor. Frustração da penhora em face da informação da inexistência de saldo nas contas bancárias. Devedor é sócio controlador de sociedades empresárias e considerado o maior revendedor de veículos da América Latina. Pedido de aplicação da desconsideração inversa da personalidade jurídica para que a penhora recaia em saldos bancários das sociedades empresárias controladas pelo devedor. Indeferimento pelo juiz de primeiro grau. Reconhecimento da possibilidade de se declarar a desconsideração da personalidade jurídica 
incidentalmente na fase de execução da sentença, não se exigindo ação autônoma, mas, observandose o contraditório, a ampla defesa e o devido processo legal. Prova de que o sócio devedor é, em rigor, "dono" da sociedade limitada e da sociedade anônima fechada, das quais é o presidente, controlador de fato, e, apesar da participação minoritária de sua esposa, ficam elas caracterizadas como autênticas sociedades unipessoais. Confusão patrimonial entre sócio e sociedades comprovada. Patrimônio particular do sócio controlador constituído de bens que, na prática, mesmo que penhorados, não seriam convertidos em pecúnia para a satisfação do credor. Oferecimento de bens imóveis à penhora, que, por se situarem no Estado da Paraíba, distantes mais de $2.600 \mathrm{~km}$ de São Paulo, onde tramita a execução, com nítido escopo de se opor maliciosamente à execução, empregando ardis procrastinatórios, que configura ato atentatório à dignidade da justiça. Agravo provido, para deferir a desconsideração inversa da personalidade jurídica das sociedades empresárias indicadas (Limitada e S/A fechada), autorizada a penhora virtual de saldos de contas bancárias." (TJSP, AI 1198103-0/0, Rel. Des. Pereira Calças, 29ª Câmara, d.j. 26.11.2008) (Grifamos)

“APELAÇÃO CÍVEL - DECLARATÓRIA - DESCONSTITUIÇÃO DE SOCIEDADE JURÍDICA SIMULAÇÃO - Suposta sócia com 0,016\% do capital social. - Ausência de participação nos lucros. Percepção de salário fixo. - Sentença de procedência do pedido. - Anulação do negócio jurídico. Honorários advocatícios fixados em R\$4.000,00. - Incompetência da justiça estadual. - Inocorrência. - Feito que visou desconstituição de personalidade jurídica, com anulação de contrato. - Ausência de ingresso na seara trabalhista, embora reconhecido o vínculo. - Simulação claramente verificada. Sócio majoritário, estrangeiro, sem qualificação técnico-profissional. - Honorários advocatícios fixados abaixo do previsto na lei processual. - Adequação ao previsto no $\$ 4^{o}$ do art. 20 , do CPC. Majoração para $R \$ 10.000,00$ (dez mil reais). - Reforma parcial da sentença. - REJEIÇÃO DA PRELIMINAR, IMPROVIMENTO DO RECURSO DOS RÉUS E PROVIMENTO PARCIAL DO RECURSO DA AUTORA.

(...)

Quanto ao mérito da demanda, convém ressaltar que no negócio jurídico realizado pelas partes e, ora impugnado, verificou-se ocorrência de simulação, na forma do artigo 167, \$ $1^{\circ}$, I do Código Civil de 2002, na medida em que simula conferir direitos aos adquirentes das cotas societárias, quando, em realidade, os confere aos alienantes, uma vez que os mantém com a gestão ilimitada da sociedade, assim demonstrado pelo mínimo percentual societário conferido à Autora, que ao que tudo demonstra, e como bem salientou a d. sentença : "elementos cognoscíveis dos autos apontam no sentido de a autora ter servido apenas para poder investir e permanecer no país, sem, contudo, possuir realmente vontade de com ela desenvolver o fim comum e partilhar lucros.”

Tratando-se, como se trata, de negócio jurídico simulado, o mesmo é nulo, insuscetível, pois, na forma do artigo 169 da Lei Civil de confirmação ou convalidação, podendo, portanto, ser objeto de anulação a qualquer tempo.

Muito embora aleguem os ora Apelantes que a Autora dispunha, inclusive, de procuração ampla para gerir o negócio, esta se verificou prática diante da impossibilidade técnica do sócio majoritário, que sempre acompanhou, de bem perto, as atividades desempenhadas por sua "sócia-minoritária".

Desta forma, não merece reparos a r. sentença apelada, que bem analisou as provas e evidências dos autos, concluindo pela anulação do negócio jurídico de constituição da sociedade”. (TJRJ, AC 43602/08, Rel. Des. Sidney Hartung Buarque, $4^{\mathrm{a}}$ Câmara Cível, d.j. 14.10.2008) (Grifamos)

"SOCIEDADE POR QUOTAS DE RESPONSABILIDADE LIMITADA. SÓCIO GERENTE POSSUIDOR DE 99,8\% DO CAPITAL SOCIAL. EXECUÇÃO FISCAL. PRESCRIÇÃO. EMBORA LONGA DEMORA NA CITAÇÃO DA FIRMA RÉ, NÃO SE CONSUMA A PRESCRIÇÃO SE O ESTADO EXEQUENTE NÃO CONCORREU PARA O ATRASO COM CULPA OU NEGLIGÊNCIA ALGUMA, DEVENDO-SE O RETARDAMENTO, INOBSTANTE AS MUITAS PETIÇÕES DO CREDOR, AO SERVIÇO CARTORIAL DEFICIENTE E ÀS PRÓPRIAS CIRCUNSTÂNCIAS DO CASO CONCRETO. SOCIEDADE REALMENTE FICTÍCIA, EM QUE O SÓCIO GERENTE E DONO DE 99,8\% DO CAPITAL SOCIAL. A PROPOSIÇÃO DE QUE A PESSOA DA SOCIEDADE NÃO SE CONFUNDE COM A DO SÓCIO É UM PRINCÍPIO JURÍDICO FUNDAMENTAL, MAS NÃO UM TABU, E MERECE SER DESCONSIDERADA QUANDO A "SOCIEDADE" É APENAS UM "ALTER EGO" DE SEU CONTROLADOR, EM VERDADE NEGOCIANTE EM NOME INDIVIDUAL. PRECEDENTE DA APELAÇÃO CÍVEL N-583018577, DA PRIMEIRA CÂMARA CÍVEL. EMBARGOS REJEITADOS. APELAÇÃO DO 
A extensão da responsabilidade social aos sócios vem sendo cada vez mais utilizada de forma desmedida e insensata.

Ora, parece-nos absolutamente injusto que alguém que não teve participação efetiva na empresa, tendo única e exclusivamente "emprestado" seu nome para permitir a obtenção da limitação da responsabilidade da empresa, seja onerado de forma ilimitada e desproporcional à sua participação na atividade e em razão de atos dos quais sequer chegou a ter conhecimento por alheio à gestão empresarial da sociedade, da qual faz parte por mero favor.

Isso sem mencionar que a sociedade, por menor que seja a participação ou influência dos demais sócios, traz consigo todas as dificuldades do relacionamento interpessoal e da affectio, sujeito a altos e baixos e a modificações repentinas como é bem sabido por todos.

Como se observa, o empresário individual busca, mediante o uso de artifícios, aquilo que a lei lhe nega: o exercício de suas atividades com responsabilidade limitada. Desse modo, faz-se absolutamente necessário que o Brasil acompanhe a evolução já ocorrida em diversos países e incorpore, no ordenamento jurídico, meios legítimos que possibilitem a limitação de responsabilidade do empresário individual, de modo a evitar tanto a oneração excessiva do patrimônio do empresário quanto a concorrência entre credores empresariais e pessoais, além de desencorajar o uso de estruturas fictícias que podem inclusive levar a injustiças como a responsabilização desproporcional de pessoas em verdade alheias aos desígnios da empresa.

Resta, agora, avaliar a solução mais adequada para estruturação de tal limitação: pela via não societária do patrimônio de afetação, ou pela forma societária, com a adoção da sociedade unipessoal.

ESTADO PROVIDA. (TJRS, AC 584036800, Rel. Des. Athos Gusmão Carneiro, $1^{\text {a }}$ Câmara Cível, d.j. 14.05.1985) 


\section{A FORMA NÃO SOCIETÁRIA DE ORGANIZAÇÃO DA LIMITAÇÃO: SEPARAÇÃO PATRIMONIAL}

Como já tivemos a oportunidade de expor, a limitação da responsabilidade tem como principal foco mitigar os riscos típicos da atividade empresarial, conferindo proteção ao investidor que não deseja comprometer todo o patrimônio adquirido ao longo da vida. Via de consequência, a limitação da responsabilidade funciona como mecanismo de incentivo ao exercício da empresa, impactando de forma positiva no desenvolvimento da economia.

A busca da limitação de responsabilidade do empresário individual deu-se, historicamente, de duas formas: pela via da sociedade unipessoal e pela via não societária da separação patrimonial, que passaremos a analisar.

\subsection{O patrimônio}

A teoria clássica do patrimônio apregoava ser este uma universalidade de direito $^{108}$, ou seja, um conjunto de relações jurídicas ativas e passivas, apreciáveis economicamente, pertencentes a um mesmo sujeito. Para esta teoria, também chamada teoria subjetiva do patrimônio, o patrimônio emanaria da personalidade e, assim como a personalidade, seria uno e indivisível, de modo absoluto.

Pela teoria clássica pode se afirmar que ${ }^{109}$ :

- somente as pessoas, naturais ou jurídicas, podem ter patrimônio;

- toda pessoa tem, necessariamente, um patrimônio, ainda que não tenha nenhum bem; e

- cada pessoa só pode ter um único patrimônio.

\footnotetext{
${ }^{108}$ Difere de universalidade de fato, que é o conjunto de coisas ligadas por vontade do homem em razão de sua destinação.

109 Cf. BARRETO FILHO, Oscar. Teoria do estabelecimento comercial: fundo de comércio ou fazenda mercantil. São Paulo: Max Limonad, 1969. p. 49.
} 
A unicidade patrimonial teria como propósitos (a) a garantia dos credores, que estariam amparados pela integralidade do patrimônio do devedor, independentemente da época de aquisição dos bens ou direitos, e (b) a fixação do estado patrimonial do de cujus no momento da abertura da sucessão ${ }^{110}$.

Tal conceito foi sendo paulatinamente relativizado, haja vista as próprias contradições legislativas quanto à unicidade patrimonial, como nos chama à atenção Sylvio Marcondes ${ }^{111}$, ao comentar o artigo $57^{112}$ do Código Civil de 1916:

"Em face de nosso direito positivo, portanto, o patrimônio e a herançapara ficar apenas nessas universalidades - são universalidades de direito. E mais. Colocado o observador na posição do herdeiro, verificase que elas coexistem, por pertinência ao mesmo titular. Sem negar aos objetos de direito o suporte do sujeito de direito, o legislador pátrio contradiz, assim, a indivisibilidade e, pois, a unicidade do patrimônio, deduzidas ambas pela teoria clássica (.....” (Grifos do original)

Nas palavras de Pontes de Miranda ${ }^{113}$,

“todo patrimônio é unido pelo titular único, ou por titulares em comum, mas únicos. Isso não quer dizer que a cada pessoa só corresponda um patrimônio; há o patrimônio geral e os patrimônios separados ou especiais. Somente a lei pode separar patrimônios."

A doutrina moderna predominante nega a ideia de unidade de patrimônio ${ }^{114}$, considerando-o como "o conjunto de bens coesos pela afetação a um fim econômico

${ }^{110}$ PEREIRA, Caio Mário da Silva. Instituições de direito civil. 12a ed. Rio de Janeiro: Forense, 1991. v. 1. p. 271.

${ }^{111}$ MARCONDES MACHADO, Sylvio. Problemas de direito mercantil. São Paulo: Max Limonad, 1970. p. 91.

112 Código Civil de 1916, Art. 57. O patrimônio e a herança constituem coisas universais, ou universalidades, e como tais subsistem, embora não constem de objetos materiais.

${ }^{113}$ PONTES DE MIRANDA, Francisco Cavalcanti, Tratado de direito privado, $3^{\mathrm{a}}$ ed., Rio de Janeiro: Borsoi, 1970, t. V, p. 379.

${ }^{114}$ Pontes de Miranda, Vicente Rao, Sylvio Marcondes Machado, Orlando Gomes, Oscar Barreto Filho e outros.

Para Caio Mário da Silva Pereira, a afetação somente implicará em composição de um patrimônio se se verificar a criação de uma personalidade. Caso contrário, eles se prendem ao fim, mas continuam encravados no patrimônio do sujeito. (Cf. PEREIRA, Caio Mário da Silva. Instituições de direito civil. $4^{\mathrm{a}}$ ed. Rio de Janeiro: Forense, 1974. v. 1. p. 342) 
determinado"115, admitindo, pois, a divisibilidade do patrimônio e a coexistência de um patrimônio geral (que abrange os direitos, pretensões, ações e exceções patrimoniais da pessoa e atende a fins gerais) e de patrimônios especiais (destinados a um fim específico $\left.^{116}\right)^{117}$.

Os patrimônios especiais são também denominados patrimônios separados, patrimônios autônomos ${ }^{118}$ ou patrimônios de afetação, pois afetos a um fim determinado.

A doutrina admite, ainda, diversas acepções para os patrimônios separados, podendo referir-se ora a massas patrimoniais sujeitas a um regime distinto dos demais componentes do patrimônio de uma pessoa ( $v g$. dote, bens dos cônjuges em comunhão) ${ }^{119}$, ora a alguma forma de limitação de responsabilidade ( $\mathrm{g}$. impossibilidade de responsabilizar o patrimônio separado pelas dívidas do titular, como no caso do bem de

\footnotetext{
${ }^{115}$ GOMES, Orlando. Introdução ao direito civil. 10ª ed. Rio de Janeiro: Forense, 1991. p. 210.

${ }^{116}$ Para Pontes de Miranda, só a lei poderia separar patrimônios (Cf. PONTES DE MIRANDA, Francisco Cavalcanti. Tratado de direito privado. $3^{\mathrm{a}}$ ed. Rio de Janeiro: Borsoi, 1970. t. V. p. 379).

${ }^{117}$ Um dos principais teóricos do patrimônio de afetação (Zweckvermögentheorie) foi Brinz.
}

Reafirmando o princípio naturalista, segundo o qual apenas pessoas naturais podem ser sujeitos de direitos e obrigações, Brinz admite a existência de patrimônios que não podem ser atribuídos aos homens, mas não vê na extensão do conceito de sujeito de direito uma solução para o problema.

Assim, Brinz procura alargar o conceito de titular de um patrimônio, de modo que, para a existência do patrimônio, seria necessária não apenas a existência de bens, mas também uma relação de "atribuição", que não existe exclusivamente entre pessoas e bens, mas também entre bens e fins. Desse modo, o ordenamento poderia determinar que uma coisa pertencesse a um fim específico.

O patrimônio afetado poderia então, em um segundo momento, ser fictamente personificado - a personificação seria, pois, subordinada ao patrimônio de afetação, tornando claro que as coisas pertencem a um determinado fim, não a um determinado ente fictício. Como consequência, a responsabilidade da pessoa natural subsistiria com relação ao fim para o qual o patrimônio existe.

(Cf. SALOMÃO FILHO, Calixto. A sociedade unipessoal. São Paulo: Malheiros, 1995. pp. 18-19)

118 De acordo com Sylvio Marcondes Machado, alguns autores, como Candian, Messineo e Pino, fazem distinção entre patrimônio separado e patrimônio autônomo.

O primeiro seria uma massa de bens separados dentro do patrimônio geral, destinados a um determinado fim, mas pertencentes ao mesmo sujeito. Já o segundo, para Candian, é aquele que se apresenta, em caráter provisório, sem um titular determinado, enquanto para Messineo é um patrimônio novo e independente, com sujeito ou finalidades próprios e objeto de direitos e obrigações, como ocorre na formação da pessoa jurídica.

Pino entende que o patrimônio autônomo, por pertencente a vários sujeitos e destinado a uma função particular, seria uma soma de diversos patrimônios separados. Assim, o conceito de patrimônio autônomo estaria no plano dos sujeitos, enquanto o de patrimônio separado estaria no plano dos objetos.

(Cf. MARCONDES MACHADO, Sylvio. Limitação de responsabilidade de comerciante individual. São Paulo: Max Limonad, 1956. pp. 234-235).

Patrimônio separado e patrimônio autônomo são, todavia, ambos considerados patrimônios de afetação, pois afetos a um fim determinado.

${ }^{119}$ GOMES, Orlando. Introdução ao direito civil. $10^{\mathrm{a}}$ ed. Rio de Janeiro: Forense, 1991. p. 209. 
família; ou limitação ao acesso dos credores por dívidas oriundas de bens separados aos bens de seu titular, como no caso do espólio em relação ao herdeiro ${ }^{120}$. Ou, ainda, em alguns casos, pode se referir às duas coisas em conjunto, como na separação patrimonial afetada a uma determinada atividade.

Nesta última hipótese, o patrimônio afetado permite ao empresário limitar o risco do negócio, de modo que dívidas decorrentes da atividade comercial não atinjam seu patrimônio pessoal. Da mesma forma, assegura aos credores por dívidas decorrentes da atividade praticada com o patrimônio afetado que os credores particulares do empresário não terão acesso àqueles bens, garantindo, por sua vez, os credores pessoais do empresário seu patrimônio geral.

Assim, se por um lado há uma diminuição da garantia patrimonial a ambas as categorias de credores - pessoais e empresariais -, essa aparente desvantagem é contrabalançada pela ausência de concorrência entre os credores de diversas classes pelos mesmos bens.

Naturalmente, caso não existisse exceção à regra do comprometimento da integralidade do patrimônio particular dos sócios, os empreendedores seriam mais cautelosos e, conseguintemente, observar-se-ia a redução de novas empresas, especialmente as mais arriscadas. Daí a relevância de se prever a limitação da responsabilidade dos empresários em geral e do empresário individual em particular.

Superada a teoria do patrimônio universal e partindo-se, pois, da admissibilidade da afetação de parte do patrimônio a uma finalidade específica, tal patrimônio estará sujeito a disciplina jurídica diversa daquela a que é submetido o patrimônio pessoal do empresário, não dando ensejo, todavia, ao surgimento de um novo ente jurídico ${ }^{121}$.

O que se pretende, em verdade, com a possibilidade de separação patrimonial é a limitação dos riscos ou, nas palavras de Ascarelli, “a constituição (...) do

\footnotetext{
${ }^{120}$ MARCONDES MACHADO, Sylvio. Problemas de direito mercantil. São Paulo: Max Limonad, 1970. p. 97.

${ }^{121}$ Ressalvada a situação do patrimônio autônomo, quando uma parcela do patrimônio pessoal do empresário é destinada, de forma definitiva, à pessoa jurídica, como aporte de capital.
} 
patrimônio separado representa apenas um meio técnico para que os sócios possam exercitar o comércio com responsabilidade limitada ${ }^{122, .}$

Desse modo, no caso do empresário individual, a adoção do patrimônio de afetação permitiria que somente os bens destinados à atividade empresarial respondessem por obrigações contraídas nesse âmbito.

Para tanto, há que se observar certos requisitos: os bens destinados à exploração empresarial devem estar livres e desembaraçados de ônus; não devem se desviar da finalidade previamente estabelecida; o empresário deve responsabilizar-se por eventual discrepância do valor estimado dos bens que compõem o patrimônio; e, caso existam dívidas no momento da afetação, o patrimônio deve ser suficiente para suportá$\operatorname{las}^{123}$.

No Brasil, no entanto, o empresário individual não se beneficia da limitação de responsabilidade decorrente da afetação patrimonial.

O empresário individual pode até chegar a destacar de seu patrimônio civil uma parcela de bens, recursos e valores para exercício da atividade comercial. Contudo, a distinção entre patrimônio civil e patrimônio empresarial do empresário individual não se reflete no plano jurídico, pois somente a lei poderia admitir a separação de patrimônios ${ }^{124}$.

Como bem sintetizou Oscar Barreto Filho ${ }^{125}$ :

"Ora, em face de nosso direito positivo, inexiste qualquer fundamento para afirmar que constitua patrimônio separado aquele núcleo de bens destinados pelo comerciante individual no exercício do comércio. $\mathrm{Na}$ verdade, o patrimônio uno do comerciante (pessoa física) constitui a garantia de todos os credores, civis ou comerciais. Ocorre diversamente

\footnotetext{
${ }^{122}$ ASCARELLI, Tullio. "Princípio e Problemas das Sociedades Anônimas". In: Problemas das sociedades anônimas e direito comparado. Campinas: Bookseller, 2001. p. 465.

${ }^{123}$ BRUSCATO, Wilges Ariana. Empresário individual de responsabilidade limitada. São Paulo: Quartier Latin, 2005. p. 180.

${ }^{124}$ É possível convencionar a limitação da responsabilidade, desde que restrita a certa quantia e até certo tempo. A limitação deve ser acordada entre credor e devedor e pode ser oposta apenas ao credor específico. (Nesse sentido, PONTES DE MIRANDA, Francisco Cavalcanti. Tratado de direito privado. $3^{\mathrm{a}}$ ed. Rio de Janeiro: Borsoi, 1970. t. V. pp. 396 e ss.)

${ }^{125}$ BARRETO FILHO, Oscar. Teoria do estabelecimento comercial: fundo de comércio ou fazenda mercantil. São Paulo: Max Limonad, 1969. p. 62.
} 
quando se organiza uma pessoa jurídica para o exercício do comércio a sociedade comercial. Neste caso, as parcelas destacadas dos patrimônios particulares de cada um dos sócios são reunidas para formar o capital da sociedade, que se apresenta como um patrimônio autônomo, independente dos patrimônios dos que contribuíram para sua integração. A autonomia do patrimônio social se justifica e fundamenta pelo fato da formação de nova pessoa jurídica, à qual é atribuída a titularidade do complexo de relações jurídicas que constituem o patrimônio. No caso da sociedade, é lícito falar de patrimônio comercial, no sentido próprio da expressão, visto que tôdas as relações jurídicas que nêle confluem são pertinentes ao exercício do comércio." (Grifos do original)

Assim, no Brasil, o empresário individual responde com todos os seus bens por todas as suas dívidas, sejam de cunho civil ou empresarial.

\subsection{Tentativas de construção da forma não societária}

Alguns autores brasileiros, como Philomeno Joaquim da Costa ${ }^{126}$ e Carlos Celso Orcesi da $\operatorname{Costa}^{127}$, defenderam a solução do problema da limitação de responsabilidade do empresário ${ }^{128}$ individual por meio da criação de um modelo não societário para o exercício da atividade.

Mas o grande defensor da teoria do patrimônio de afetação como forma de limitação da responsabilidade do empresário individual no Brasil foi, sem dúvida, Sylvio Marcondes Machado, em sua tese de $1956^{129}$.

\footnotetext{
${ }^{126}$ COSTA, Philomeno Joaquim da. "Comentário a acórdão". In: Revista de Direito Mercantil Industrial, Econômico e Financeiro, v. 53, 1984.

${ }^{127}$ COSTA, Carlos Celso Orcesi da. "Empresas unipessoais". In: Revista de Direito Mercantil Industrial, Econômico e Financeiro, v. 51, 1983.

128 À época adotava-se a denominação "comerciante", que preferimos, no presente trabalho, adaptar à mais moderna terminologia de empresário.

${ }^{129}$ O autor já havia abordado a questão da limitação de responsabilidade em obra prévia, Ensaio sobre a sociedade de responsabilidade limitada (São Paulo: RT, 1940).
} 
Já no início de sua tese o autor afirma ${ }^{130}$ :

“O princípio da responsabilidade ilimitada, consagrado nas legislações e segundo o qual a pessoa responde por suas dividas com todos os bens, constitui o eixo de um inteiro sistema organizado no plano jurídico para promover a segurança das relações dos homens, na ordem econômica. Sujeitando a massa dos bens da pessoa à satisfação de suas obrigações, a lei, de uma parte, confere aos credores garantias contra o inadimplemento do devedor; de outra, impõe a este uma conduta de prudência na gestão dos próprios negócios. E, assim, refreia a aventura, fortalece o crédito e incrementa a confiança.

Não obstante, setores há de atividade, no campo da economia, em que a aplicação do princípio deve sofrer atenuações, sob pena de entrave ao progresso dos empreendimentos humanos."

Marcondes entende que o patrimônio separado configura base objetiva propícia à demarcação de uma área patrimonial que permita limitar a extensão da responsabilidade.

Partindo do conceito clássico de relação obrigacional como um vínculo de direito que liga a pessoa do devedor à do credor, restringindo a vontade do devedor (que não pode se libertar do vínculo por seu simples arbítrio) e concedendo ao credor o direito de constrangê-lo a determinada atividade (ou, na sua falta, à satisfação do crédito com o patrimônio do devedor), o autor se filia à posição germânica de independência dos conceitos de dívida (Schuld) e responsabilidade (Haftung).

Segundo os defensores da tal teoria, a dívida seria uma relação de dever, enquanto a responsabilidade seria uma relação de sujeição de uma pessoa, coisa ou patrimônio a outra, em garantia de um débito existente.

Assim sendo, Schuld, o dever de prestar, seria um dever meramente pessoal do sujeito passivo da relação obrigacional, correspondendo a um direito também pessoal do sujeito ativo. Já Haftung, o dever de permitir a satisfação sobre o patrimônio,

\footnotetext{
${ }^{130}$ MARCONDES MACHADO, Sylvio, Limitação de responsabilidade de comerciante individual, São Paulo: Max Limonad, 1956, pp. 19-20.
} 
corresponderia a um direito real e absoluto do sujeito ativo da obrigação. A distinção entre dívida e responsabilidade, contudo, não excluiria a concepção unitária da obrigação ${ }^{131}$.

A técnica da distinção entre dívida e responsabilidade é fundamental à tese em análise, pois leva, em última instância, à crítica feita por Gangi e Messineo, com o que Marcondes concorda, de que o sentido habitualmente concedido à "responsabilidade limitada”, qual seja, a determinação de certa importância pelo qual responde o devedor, é impreciso, pois a limitação seria, propriamente, da dívida, e não da responsabilidade.

O devedor responderia, pois, de forma ilimitada, com todos os seus bens, mas por uma dívida limitada.

A limitação de responsabilidade, a rigor, dar-se-ia apenas quando se demarcasse uma área circunscrita de bens destinada a suportar os direitos dos credores dita responsabilidade objetivamente limitada - já que a responsabilidade pela dívida estaria delimitada ao valor dos objetos sobre o qual tal responsabilidade recai, não podendo o credor exigir senão aqueles em caso de insatisfação da dívida.

Em resumo, pode-se afirmar que, pela tese exposta, as pessoas jurídicas de "responsabilidade limitada", nas quais o capital social é garantia dos credores e determina, quantitativamente, o limite da responsabilidade perante terceiros, são, em realidade, entidades com responsabilidade ilimitada, mas "dívida limitada". A verdadeira limitação de responsabilidade somente poderia ser alcançada pela separação patrimonial, circunscritos os bens responsáveis, de modo que patrimônio separado e responsabilidade limitada, nas palavras de Sylvio Marcondes, "como irmãos siameses, se conjugam numa unidade permanente e indissolúvel" ${ }^{, 132}$.

E é nessa conjugação que o autor encontra fundamento para a elaboração do conceito jurídico de empresa individual com responsabilidade limitada.

\footnotetext{
${ }^{131}$ Alguns doutrinadores contrários à teoria da independência entre dívida e responsabilidade, como Ferrara, objetam que o dever jurídico tem como conteúdo imanente a coação e, portanto, a responsabilidade nada mais seria do que a consequência da relação obrigacional. Seriam, pois, conceitos distintos, mas não relações independentes.

${ }^{132}$ MARCONDES MACHADO, Sylvio. Limitação de responsabilidade de comerciante individual. São Paulo: Max Limonad, 1956. p. 272.
} 
Observe-se que o autor não descarta a possibilidade da personalização como concepção para limitação da responsabilidade no exercício do comércio (ou limitação da dívida, como visto), mas propugna que a escolha entre personificação e separação de patrimônio depende da melhor adaptação aos princípios concernentes à matéria no sistema de direito privado.

Atribuindo-se personalidade jurídica à empresa individual, separar-se-ia esta da pessoa do empresário, que teria, assim, limitado sua responsabilidade ao ato inicial constitutivo da nova pessoa jurídica. A empresa seria, pois, sujeito de direito autônomo com relação a seu criador.

Marcondes entende, contudo, ser tal opção inviável e o justifica com base na classificação das pessoas jurídicas de direito privado ${ }^{133}$, separadas em corporações ${ }^{134} \mathrm{e}$ fundações. As corporações seriam resultantes da conjugação de vontades - dependendo, portanto, de mais de uma pessoa para sua constituição. A empresa singular também não encontraria guaridas na classe das fundações. Desse modo, segundo o autor, seria necessária a criação pelo legislador de uma categoria sui generis de pessoas jurídicas de direito privado para abrigar as sociedades individuais.

E, ainda que suplantado o problema da delimitação das pessoas jurídicas de direito privado, em razão da teoria da independência entre Schuld e Haftung a empresa individual, mesmo personalizada ${ }^{135}$, não teria responsabilidade limitada, e sim dívida limitada ao valor do capital da empresa, responsabilizando-se o seu fundador com todo seu patrimônio pelo cumprimento de tal dívida e responsabilizando-se a empresa com todos os

${ }^{133}$ Nos termos do artigo 16 do Código Civil de 1916, são pessoas jurídicas de direito privado:

I. as sociedades civis, religiosas, pias, morais, científicas ou literárias, as associações de utilidade pública e as fundações;

II. as sociedades mercantis;

III. os partidos políticos.

No Código Civil de 2002, a classificação consta do artigo 44, que determina que são pessoas jurídicas de direito privado:

I. as associações;

II. as sociedades;

III. as fundações.

${ }^{134} \mathrm{O}$ termo corporações abarca as sociedades e associações.

135 Para Marcondes, o processo evolutivo da limitação de responsabilidade nas formas modernas de sociedades comerciais trouxe como progresso o fato de permitir à totalidade dos associados a fixação prévia e insuperável da dívida de cada um, e não propriamente a limitação da responsabilidade. 
seus bens perante seus próprios credores. Ou seja, a responsabilidade seria, de ambos os prismas, ilimitada.

Uma vez descartada pelo autor a possibilidade de personalização da empresa singular, Marcondes passa a defender a delimitação da responsabilidade do comerciante individual pela concepção da empresa como patrimônio.

O complexo de relações jurídicas formadas pela atividade empreendedora, tendo à frente o empresário singular, dá lugar a um patrimônio especial, distinto, por seu fim, do restante do patrimônio do empresário. Essas relações ativas e passivas formam uma universalidade de direito (em razão do fim comum), mas não se desligam da titularidade do empresário.

Superada a questão quanto à unicidade do patrimônio $^{136}$ e admitida a existência de mais de uma universalidade subordinada ao mesmo sujeito de direitos - ou patrimônios separados - chega-se ao modelo de empresa individual defendido na tese ora em análise. O patrimônio separado, então, centralizaria as relações jurídicas emergentes da atividade do empresário singular, imprimindo cunho jurídico ao conceito econômico de empresa $^{137}$.

A empresa individual com responsabilidade limitada seria, pois, objeto de direito pertencente ao empresário, mantendo-se com este a qualidade de sujeito de direito e titular das obrigações decorrentes.

\footnotetext{
${ }^{136}$ Vide item 4.1.

${ }^{137}$ Aplica-se aqui a noção de empresa como atividade, em seu perfil funcional.
}

De acordo com Asquini, "il concetto di impresa é il concetto di um fenomeno econômico poliédrico, il quale ha sotto l'aspetto giuridico non uno, ma diversi profili in relazione ai diversi elementi che vi concorrono."

O eminente jurista italiano identificou quatro perfis da empresa:

- o perfil subjetivo, que identifica a empresa com a figura do empresário;

- o perfil funcional, em que a empresa é tida como a atividade empresarial dirigida a um escopo produtivo;

- o perfil objetivo (ou patrimonial), que identifica a empresa com seu patrimônio, o conjunto de bens destinado ao exercício da atividade empresarial (estabelecimento ou azienda); e

- o perfil corporativo, pelo qual a empresa seria uma instituição, uma organização de pessoas formada pelo empresário e por seus prestadores de serviço, um núcleo social organizado em função de um fim econômico comum.

(Cf. ASQUINI, Alberto. "Profili dell'impresa". In: Rivista di diritto commerciale, vol. XLI, parte I, 1943) 
O artigo 1.143 do Código Civil vigente, inclusive, prevê tal possibilidade, ao dispor que "[p]ode o estabelecimento ser objeto unitário de direitos e de negócios jurídicos, translativos ou constitutivos, que sejam compatíveis com a sua natureza."

Contudo, nada obstante a abertura quanto à separação patrimonial do estabelecimento, não há qualquer previsão relativamente à limitação de responsabilidade do empresário a este patrimônio, exclusivamente, valendo aqui a regra geral da responsabilidade pessoal ilimitada.

\subsection{Crítica à limitação de responsabilidade pela via do patrimônio de afetação}

Do exposto, verifica-se que os defensores da limitação de riscos do empresário individual pela via da regulamentação legislativa do patrimônio de afetação entendem desnecessária a criação de uma pessoa jurídica para consecução da responsabilidade limitada, sendo preciso, apenas, delimitar com exatidão o complexo de bens que servem de garantia aos credores em razão de negócios intentados com o empresário individual.

Contudo, tal expediente traz uma série de inconvenientes, como a dificuldade de transmissão da empresa a terceiros, a impossibilidade de ampliação do negócio e de obtenção de crédito descolado da figura do empresário e a dificuldade em manter a separação patrimonial e a necessária distinção entre o empresário e a pessoa jurídica empresária.

Em se tratando a empresa individual com responsabilidade limitada de um patrimônio separado e, portanto, de uma universalidade, sua transferência seria, de certa forma, limitada. Isso porque, visando à garantia dos credores, é vedada a transferência a terceiros de estabelecimento sem que haja o consentimento dos credores respectivos e sem que o empresário tenha bens suficientes para resolver o passivo ${ }^{138}$.

Nos termos do artigo 1.145 do Código Civil, se ao alienante não restarem bens capazes de fazer frente ao passivo, a alienação do estabelecimento (trespasse) será

${ }^{138} \mathrm{Na}$ vigência da norma falimentar antiga (Decreto-Lei $\mathrm{n}^{\circ}$ 7.661/45), a vedação estava prevista nos artigos $2^{\circ}$, V e 52, VIII. Atualmente, a regulamentação encontra-se na Lei no 11.101/05, art. 94, III, "c" e art. 129 , VI. 
ineficaz, salvo em caso de pagamento de todos os credores ou do consentimento expresso ou tácito destes no prazo de 30 dias a partir de sua notificação.

O adquirente do estabelecimento é responsável por todos os débitos anteriores à transferência, desde que regularmente contabilizados. $\mathrm{O}$ alienante, por sua vez, permanece solidariamente responsável pelos créditos vencidos pelo prazo de um ano, a partir da publicação na imprensa oficial do trespasse, e, pelos créditos vincendos, por até um ano a contar das respectivas datas de vencimento.

Demais disso, o encerramento da empresa (que, por óbvio, não comporta a fase de dissolução, mas apenas de liquidação) se dá, como nas sociedades, mediante pagamento dos credores ou requerimento de falência. Neste caso, a preservação da empresa é dificultada, uma vez que a transferência a terceiros (inclusive herdeiros) depende, como visto, de consentimento dos credores.

A extinção em razão da morte do empresário acarretaria a liquidação da empresa no juízo do inventário.

Em princípio, a insolvência da empresa singular acarreta, necessariamente, a falência do empresário, como sujeito de direito e titular das execuções dos credores, vez que a empresa individual não ostenta personalidade jurídica separada e independente da de seu titular. No caso da adoção da empresa individual com responsabilidade limitada pela separação do patrimônio, a legislação teria de ser adaptada, uma vez que a tal extensão da falência à figura do empresário faria cair por terra a limitação de responsabilidade alcançada pela via da especialização patrimonial.

Desse modo, há que se fazer uma construção jurídica na qual o empresário seja sujeito passivo das ações dos credores, como titular das relações jurídicas da empresa, mas em que a execução, contudo, fique adstrita aos bens existentes no patrimônio da empresa (patrimônio especial). A implicação disso, todavia, é a restrição ao caráter de unicidade e generalidade da falência ${ }^{139}$.

Sylvio Marcondes propõe, como alternativa, que o legislador dissocie a titularidade da capacidade contratual (relativa à prática de relações de direito material) da

${ }^{139}$ Segundo o STJ, o princípio da unicidade e universalidade do juízo falimentar, previsto no art. $7^{\circ}$, $\S 2^{\circ}$ da antiga Lei de Falências, não é absoluto, comportando exceções. Cf. REsp 467516/MT, Rel. Min. Nancy Andrighi, Terceira Turma, d.j. 20.03.2006. 
titularidade da capacidade processual (relativa à prática de relações de direito formal) na relação empresário-empresa, similarmente ao que ocorre com os herdeiros e o espólio, ou a massa falida e o administrador. Assim sendo, a titularidade das relações produzidas pela capacidade civil do sujeito permaneceria a cargo do empresário individual, enquanto a titularidade das relações formais seria investida na empresa, que se legitimaria como sujeito passivo no processo de falência, representada por seu titular, bem como em quaisquer ações que tivessem como foco as relações ativas e passivas resultantes da atividade empresarial $^{140}$.

Outro ponto negativo que se pode citar com relação à limitação de responsabilidade via patrimônio de afetação é a impossibilidade de ampliação do negócio, uma vez que não é possível agregar novos membros ${ }^{141}$ ou mesmo incluir ou excluir bens do patrimônio especial, sob pena de violação das garantias ora dos credores particulares do empresário, ora dos credores empresariais.

Os frutos dos bens afetos ao estabelecimento, no entanto, como já visto, integram o patrimônio - o que dá azo a outro ponto crítico, qual seja a distribuição dos resultados. Se todo o resultado da empresa for revertido em benefício desta, o empresário terá sua subsistência prejudicada. Nada obstante, os rendimentos do patrimônio de afetação não se comunicam com o patrimônio geral ou outros patrimônios especiais.

Desse modo, seria necessária previsão expressa, como existente na legislação portuguesa do Estabelecimento Individual de Responsabilidade Limitada $(\text { EIRL })^{142}$, no sentido de que os lucros comprovados em balanço decorrentes da atividade empresarial possam ter como destinatário o próprio empresário, a fim de evitar confusões relativamente à separação patrimonial.

\footnotetext{
${ }^{140}$ MARCONDES MACHADO, Sylvio. Limitação de responsabilidade de comerciante individual. São Paulo: Max Limonad, 1956. pp. 330-334.

${ }^{141}$ A inclusão de novos sócios só é possível mediante transformação do empresário individual em sociedade, nos termos do parágrafo $3^{\circ}$ do artigo 968 do Código Civil, inserido pelas recentes transformações trazidas pela Lei Complementar $n^{\circ}$ 128, de 19.12.2008. Contudo, nesse caso, o patrimônio especial perde objeto, passando a ser parte do patrimônio social e garantida a limitação de responsabilidade pela pluralidade de sócios, se adotada a forma de limitada.

${ }^{142}$ Vide, nesse sentido, item 6.3 abaixo.
} 
Demais disso, a limitação de responsabilidade que pode ser obtida pela afetação patrimonial não permite ao empresário individual ter acesso a crédito descolado de sua pessoa, o que, a nosso ver, é um dos pontos mais desfavoráveis à solução não societária.

Finalmente, ressalta-se a dificuldade em manter, perante terceiros, a necessária distinção entre o empresário e o estabelecimento. Inexistindo a "capa" da personalidade jurídica, senão meramente uma separação patrimonial, dificulta-se a apreensão, por terceiros, do relacionamento efetivo - se com o empresário, situação em que vigora a responsabilização pessoal, ou com o estabelecimento, de responsabilidade limitada. A confusão se assevera tendo-se em conta a adoção, pelo estabelecimento, da firma, e não denominação social. Assim, a distinção apresenta-se bastante tênue, sendo passível de causar confusão, o que se deve pretender evitar a todo custo.

Diante do exposto, é possível afirmar que, apesar de viável, a solução de limitação da responsabilidade do empresário individual pela via não societária da constituição de patrimônios de afetação está distante de ser a solução ideal e mais adequada ao ordenamento pátrio.

Por outro lado, verifica-se não haver qualquer impedimento objetivo à solução societária, mas sim barreiras de ordem exclusivamente conceitual e doutrinária, alegando aqueles que se opõem à sociedade unipessoal, simplesmente, ser esta contrária aos princípios (contratualistas) que regem o direito privado e não haver a necessária conjugação de mais de uma vontade para sua constituição, o que as deixaria de fora da classificação das pessoas jurídicas de direito privado.

São, contudo, argumentos que não prevalecem, como se passa a analisar. 


\section{O RECONHECIMENTO DA SOCIEDADE COM UM SÓ SÓCIO}

Como se pôde observar dos desenvolvimentos das teorias não societárias analisados no item anterior, inexistem quaisquer óbices teóricos ao reconhecimento da sociedade unipessoal. O preconceito relativo à unipessoalidade societária é de caráter meramente pragmático, haja vista a dificuldade de introdução de um tipo organizativo societário em ambientes fortemente contratualísticos.

Isso porque o conceito de sociedade esteve historicamente ligado à pluralidade de sujeitos. Entendia-se que a forma associativa apenas se justificava como uma maneira de unificar a pluralidade de sócios a ela subjacente, sendo a personalidade jurídica destinada exclusivamente a essa finalidade ${ }^{143}$.

Todavia, ao longo do tempo, o conceito de sociedade evoluiu, passando-se da teoria institucionalista germânica e da escola contratualista italiana à análise do contrato associativo e a teoria do contrato-organização, que vê no contrato social a função de criar uma organização, independentemente do número de pessoas envolvidas. A teoria do contrato-organização deu espaço à discussão sobre a unipessoalidade e, até mesmo, à existência de sociedades sem sócios ${ }^{144}$.

\subsection{Teoria institucionalista}

A concepção da sociedade como instituição teve maior desenvolvimento na Alemanha do pós primeira guerra, quando da consolidação, por Walter Rathenau, da teoria da Unternehmen an sich ("empresa em si”)" ${ }^{145}$.

\footnotetext{
${ }^{143}$ PRADO FILHO, José Inácio Ferraz de Almeida. "Notas sobre as sociedades fictícias, ou de favor", In: Revista de Direito Mercantil Industrial, Econômico e Financeiro, v 134, 2004. p. 85.

${ }^{144}$ Cf. FERRO-LUZZI, Paolo. I contratti associativi. Milano: Giuffré, 2001.

A possibilidade de adoção da sociedade sem sócios não será desenvolvida no presente estudo, por fugir ao seu objeto.

${ }^{145}$ Concebida com base no trabalho de Walter Rathenau denominado Vom Aktienwesen - Ein geschäftliche Betrachtung, publicado em 1917.
} 
A grave crise econômica então instalada no país levou aquele autor a identificar em cada empresa um instrumento a serviço do fortalecimento da Alemanha. Segundo sua teoria, que busca traduzir em termos jurídicos a função econômica da empresa, o interesse da empresa (ou sociedade ${ }^{146}$ ) não se confunde com os interesses de seus sócios.

A empresa seria, pois, um instrumento a serviço do interesse coletivo (em oposição ao interesse meramente privado dos sócios) e teria por função, dado seu caráter eminentemente público, contribuir de forma relevante para o desenvolvimento do país, gerando emprego e renda e fomentando o progresso.

Nesse sentido, há uma valorização do papel dos órgãos de administração em detrimento dos acionistas, uma vez os administradores seriam "neutros"147 e, portanto, aptos a defender o interesse da empresa. A depreciação da relevância da assembleia de acionistas acabou por influenciar negativamente os direitos dos minoritários ${ }^{148}$.

O institucionalismo postula o reconhecimento das diversas categorias de interesse, quais sejam, dos sócios, dos trabalhadores e da coletividade. Nesse diapasão, com a evolução da teoria foram criadas leis que regulamentavam a participação dos trabalhadores nos órgãos diretivos das empresas, que é uma das características marcantes do sistema societário alemão.

Em realidade, o institucionalismo vem a reconhecer que o interesse social não se reduz ao interesse dos sócios, mas se traduz no interesse de preservação da empresa, de continuidade da sociedade.

\footnotetext{
146 Rathenau não fazia distinção entre os conceitos de empresa e sociedade por ações (Unternehmen e Aktiengesellschaft). Trata-se de uma teoria fortemente baseada em conceitos econômicos, o que prejudica o correto enquadramento jurídico dos conceitos.

147 Conforme bem assevera Calixto Salomão Filho, a administração em geral está ligada ao grupo de controle da sociedade e, portanto, não se pode afirmar que seja neutra ou imparcial. Cf. SALOMÃO FILHO, Calixto. A sociedade unipessoal. São Paulo: Malheiros, 1995. p. 36.

${ }^{148}$ A teoria institucionalista passou a sofrer fortes críticas a partir dos anos 50, por pregar a independência da administração com relação aos acionistas. A lei acionária alemã de 1965 mitigou o caráter institucional e reforçou o papel da assembleia e os direitos dos minoritários. SALOMÃO FILHO, Calixto. O novo direito societário. $2^{\mathrm{a}}$ ed. reformulada. São Paulo: Malheiros, 2002. p. 32.
} 
Trata-se de um institucionalismo mais organizativo, que não se preocupa em preservar o conceito de personalidade jurídica. E, por não considerar a personalidade jurídica como algo intocável, admite a repressão à sua utilização abusiva e fraudulenta ${ }^{149}$.

Considerando-se que o interesse social coincide com o interesse à preservação da empresa, há outros valores envolvidos além daqueles que importam aos acionistas, de modo que a quantidade de sócios da empresa é irrelevante, admitindo-se a unipessoalidade. Importa, apenas, criar, nas sociedades unipessoais, garantias organizativas equivalentes àquelas existentes para sociedades com uma pluralidade de sócios, para contrabalançar o desaparecimento das relações intrassociais ${ }^{150}$.

Outro grande defensor da teoria institucionalista foi o francês Maurice Hauriou, que, como brevemente analisado no item 2.3.4 acima, entende que a instituição é uma organização com fins comuns aos membros que a compõem, sendo convertida automaticamente em pessoa jurídica dependendo de seu grau de concentração e de organização.

\subsection{Teoria contratualista}

Em oposição à teoria institucionalista, a doutrina e jurisprudência da Itália, onde a teoria contratualista teve seu maior desenvolvimento, sustentam ser o interesse social coincidente com o interesse do grupo de sócios - qual seja, a maximização do lucro. Desse modo, na noção clássica contratualista, que tem Jaeger como seu maior expoente, o interesse social seria depurado de elementos externos, sendo sempre equivalente ao interesse dos sócios atuais.

Uma segunda vertente da teoria contratualista considera como interesse social não só o interesse dos sócios atuais, mas também o interesse dos sócios futuros. Como aponta Jaeger ${ }^{151}$ - que se opunha a tal vertente -, isso leva a uma maior relevância do interesse à preservação da empresa, se assemelhando, portanto, ao institucionalismo.

\footnotetext{
${ }^{149}$ DINIZ, Gustavo Saad. Responsabilidade dos administradores por dívidas das sociedades limitadas. Porto Alegre: Síntese, 2003. pp. 54-55.

${ }^{150}$ SALOMÃO FILHO, Calixto. A sociedade unipessoal. São Paulo: Malheiros, 1995. p. 50.

${ }^{151}$ JAEGER, Pier Giusto. L'interesse sociale. Milano: Giuffré, 1964. p. 89.
} 
Para a doutrina contratualista, um contrato de sociedade criaria relações vinculantes apenas entre os sócios, e não dos sócios com a sociedade. Assim, com o desaparecimento da pluralidade de sócios desapareceria qualquer relação jurídica, tornando-se impossível distinguir entre interesse do sócio e da sociedade. O interesse da sociedade ficaria reduzido ao interesse do sócio, a quem, em razão da ausência de contraposição de interesses, seria dado utilizar a sociedade em seu exclusivo interesse, como coisa própria ${ }^{152}$. Em razão disso, a legislação italiana previa a responsabilidade ilimitada do sócio único.

A ideia contratualista de interesse social, todavia, não pôde prevalecer face à existência das macroempresas de capital aberto, haja vista não ser possível admitir que o interesse social seja estabelecido em função do grupo de sócios atuais, que é indefinido. $\mathrm{O}$ próprio Jaeger, em sua obra L'Interesse Sociale Rivisitato (quarant'anni dopo) ${ }^{153}$, reviu sua posição, passando a considerar o interesse social como equivalente ao interesse dos acionistas na maximização do valor de venda de suas quotas ${ }^{154}$.

\subsection{Do contrato plurilateral ao contrato-organização}

Muito se discutiu na doutrina o caráter contratual da constituição da sociedade. Enquanto alguns o negavam, haja vista a dificuldade de aplicação, ao conceito de sociedade, de muitos dos princípios da teoria geral dos contratos, afirmando tratar-se a constituição da sociedade de um ato complexo ${ }^{155}$, a maioria dos doutrinadores ainda defendia sua essência de contrato.

${ }^{152}$ SALOMÃO FILHO, Calixto. O novo direito societário. $2^{\text {a }}$ ed. reformulada. São Paulo: Malheiros, 2002. p. 28.

153 JAEGER, Pier Giusto. "L'interesse sociale rivisitato (quarant'anni dopo)". In: Giurisprudenza Commerciale, Milano: Giuffrè, 2000. pp. 795 e ss.

${ }^{154}$ Para Calixto Salomão Filho, essa identificação, comum no direito norte-americano, tem efeitos deletérios. A predefinição do interesse social (i.e. maximização do valor das quotas sociais) privaria os órgãos sociais de qualquer influência, engessando o desenvolvimento do direito societário.

Demais disso, haveria um estímulo à busca desenfreada de aumento do valor de venda das ações pelos agentes do mercado, dando margem à interpretação permissiva de regras contábeis ou mesmo maquiagem de balanços, como no célebre caso Enron, de 2001, que levou à promulgação do Sarbanes-Oxley Act.

(Cf. SALOMÃO FILHO, Calixto. $O$ novo direito societário. $2^{\mathrm{a}}$ ed. reformulada. São Paulo: Malheiros, 2002. p. 30)

${ }^{155} \mathrm{Na}$ teoria do ato complexo, as partes teriam interesses idênticos, e não contrapostos, como na teoria dos contratos. 
Tullio Ascarelli, em sua clássica obra Problemas das Sociedades Anônimas e Direito Comparado, dá novos ares à teoria contratualista, ao diferenciar os contratos de sociedade dos contratos em geral. Afirma aquele autor que ${ }^{156}$ :

“Na realidade, pode dizer-se tradicional a sensação da diferença entre o contrato de sociedade e os contratos que poderíamos dizer, genericamente, de permuta, e, realmente, a doutrina sempre examinou alguns problemas (por exemplo, o da exceptio inadimpleti contractus) em relação aos quais algumas regras gerais dos contratos pareciam de difícil aplicação ao contrato de sociedade".

Para Ascarelli, o contrato de sociedade, levando-se em conta suas características formais, pode ser encaixado como uma subespécie da categoria dos contratos, a que denomina contrato plurilateral ${ }^{157}$. Essa subespécie se diferenciaria dos contratos em geral por permitir a participação de mais de duas partes e pelo fato de que todas as partes possuem direitos e obrigações recíprocos decorrentes do contrato. $\mathrm{O}$ contrato teria um cunho instrumental quanto à disciplina das sucessivas relações jurídicas das partes.

Assim, pode-se afirmar que, no momento da constituição da sociedade, as parte têm interesses distintos e, muitas vezes, contrapostos ${ }^{158}$. Uma vez constituída, no entanto, a sociedade visa a uma finalidade comum a todos os sócios.

Ascarelli discorre sobre uma série de distinções que podem ser feitas entre os contratos plurilaterais e os contratos a que denomina de permuta ${ }^{159}$, e termina por

\footnotetext{
156 ASCARELLI, Tullio. Problemas das sociedades anônimas e direito comparado. Campinas: Bookseller, 2001. p. 373.

${ }^{157} \mathrm{O}$ contrato de sociedade constituiria a subespécie mais importante dos contratos plurilaterais, mas não a única.

${ }^{158}$ Como na avaliação das contribuições, ingerência na administração, participação de cada parte.

${ }^{159}$ Dentre as principais distinções, destacamos:
}

(a) nos contratos plurilaterais podem participar mais de duas partes, enquanto nos contratos de permuta há sempre duas e somente duas partes (nada obstante cada uma das partes poder ser formada por vários participantes);

(b) nos contratos plurilaterais as partes têm obrigações e adquirem direitos para com todas as outras partes (i.e. para com a sociedade), enquanto nos contratos de permuta os direitos e obrigações são de uma parte à outra;

(c) nos contratos plurilaterais existe um fim comum perseguido pelas partes, enquanto nos contratos de permuta o escopo identifica-se com a função típica do próprio contrato; 
concluir que o contrato plurilateral, em sua função econômica, constitui um contrato de organização.

Paolo Ferro-Luzzi também salienta que instrumentos contratuais tradicionais não são aptos a regular o fenômeno associativo ${ }^{160}$. Isso porque o conceito de contrato é decorrente de um momento jurídico tipicamente individualista, enquanto o fenômeno associativo é um conceito coletivo, devendo sua análise ser feita de forma objetiva, depurada de elementos subjetivos.

Segundo aquele autor, o fenômeno associativo manifesta-se juridicamente por meio do contrato associativo, ou contrato-organização. Enquanto nos contratos tradicionais, ditos "de escambo", o ponto fundamental é a atribuição às partes de direitos subjetivos, a função dos contratos associativos é criar uma organização sobre o patrimônio, ligando-o ao fim previamente estabelecido.

Os contratos de escambo teriam como efeito jurídico a criação, modificação e extinção de relações jurídicas. Já o contrato associativo giraria em torno da criação, modificação e extinção de organizações, cujo conceito jurídico é o da coordenação da influência recíproca entre atos, pressupondo a noção de atividade ${ }^{161}$.

(d) nos contratos plurilaterais a execução das obrigações das partes é premissa para uma atividade ulterior, enquanto os contratos de permuta se exaurem quando executadas as obrigações de cada parte;

(e) os contratos plurilaterais visam a disciplinar a utilização dos bens, enquanto os contratos de permuta visam à distribuição dos bens entre os sujeitos de direito;

(f) os contratos plurilaterais são, necessariamente de execução continuada, enquanto os contratos de permuta são, em sua maioria, de execução instantânea;

(g) nos contratos plurilaterais todas as partes têm direitos de um mesmo tipo, diferenciados quantitativamente, mas não qualitativamente, enquanto nos contratos de permuta o direto de cada parte é contraposto ao da outra parte (neste ponto, faz-se um pequeno aparte com relação aos diferentes tipos de classes de ações, hipótese em que há sócios com direitos qualitativamente diferentes, mas mantém-se a ideia geral de que, dentro de uma mesma classe, todos os sócios têm iguais direitos); e

(h) nos contratos plurilaterais o vício de uma das manifestações que concorrem para a formação do contrato importa em nulidade ou anulabilidade da manifestação, mas não do contrato, enquanto nos contratos de permuta o vício de uma das manifestações de vontade implica, necessariamente, em vício de todo o contrato.

${ }^{160}$ FERRO-LUZZI, Paolo. I contratti associativi. Milano: Giuffré, 2001. p. 234.

161 CATAPANI, Márcio Ferro. "Os contratos associativos”. In: FRANÇA, Erasmo Valladão Azevedo e Novaes (org.). Direito societário contemporâneo I. São Paulo: Quartier Latin, 2009. p. 94. 
A visão, pois, centra-se na coordenação de atos, e não nos participantes. A criação da organização independe da coincidência de interesses de diversos sócios, pois é possível que uma única pessoa tenha interesse em criar uma organização. Assim, a teoria do contrato-organização abre espaço para o reconhecimento da sociedade unipessoal como contrato associativo, e até mesmo da sociedade sem sócio, inclusive nos sistemas contratualistas.

As sociedades corresponderiam, desse modo, a estruturas organizativas que servem de instrumento à obtenção de determinados fins. Assim, desloca-se a ideia de pluralidade de partes para uma ideia de estrutura corporativa. O contrato de sociedade é um contrato de organização, assim entendida como um centro de imputação, estruturação do comando, desenho de responsabilidades e deveres de administradores ${ }^{162}$.

Mas como definir o interesse social, se o contrato de sociedade não é um ato de criação de direitos subjetivos para os sócios e, portanto, a organização criada não justifica sua existência a partir exclusivamente do interesse dos sócios? O interesse seria composto pela busca do lucro empresarial em equilíbrio com a preservação da empresa princípios pelos quais se deve pautar a atividade social ${ }^{163}$.

A organização criada pelo contrato associativo é sujeito de direitos e obrigações, um centro de imputação de direitos e deveres, devendo, pois, observadas as formalidades legais, ser-lhe atribuída personalidade jurídica. E, uma vez criada a pessoa jurídica, quando se misturarem interesse social e interesse individual, pode e deve ser aplicada a teoria da desconsideração da personalidade.

O contrato de sociedade tem como escopo e finalidade a organização dos fatores de produção para exercício da empresa. A ideia de organização desloca-se, pois, de uma posição estrutural no contrato de sociedade e passa a exercer um papel funcional ${ }^{164}$.

\footnotetext{
162 SZTAJN, Rachel. “Associações e sociedades”. In: Revista de Direito Mercantil Industrial, Econômico e Financeiro, v. 128, 2002. p. 19.

${ }^{163}$ SALOMÃO FILHO, Calixto. A sociedade unipessoal. São Paulo: Malheiros, 1995. pp. 59-61.

${ }^{164}$ SZTAJN, Rachel. Contrato de sociedade e formas societárias. São Paulo: Saraiva, 1989. p. 37.
} 


\subsection{A superioridade da forma societária sobre a técnica do patrimônio de afetação}

A limitação de responsabilidade é um dos grandes benefícios da sociedade unipessoal, mas não o único, como se verá, até mesmo porque esta pode ser obtida também pela via da separação patrimonial.

Nos ensina Sylvio Marcondes Machado, citando as lições de Messineo, que a grande utilidade prática da criação de um patrimônio separado é reservar, para certo grupo de credores, determinado núcleo de bens sobre o qual possa ser satisfeito, com exclusão de outros credores ${ }^{165}$, vez que o patrimônio separado não sofre os efeitos de outras obrigações de seu titular.

Como analisado anteriormente no presente trabalho, porém, a limitação de responsabilidade que pode ser obtida pela afetação patrimonial tem uma série de implicações negativas relativamente à transmissão e ampliação do negócio e à dificuldade em manter a separação patrimonial, além do fato de sua adoção no direito pátrio não se dar, como querem alguns, de forma tranquila, mas depender de uma série de adaptações legislativas.

A criação de uma pessoa jurídica separada que garanta tal limitação, na forma da sociedade unipessoal, por outro lado, permite a ampliação na circulação e liquidez da empresa e possibilita sua independência e perpetuidade em relação à figura do empresário, facilitando sua conservação para além da vida do sócio único ao simplificar o processo hereditário e de transmissão da empresa, o que se adéqua perfeitamente ao atual contexto de preservação da empresa trazido pelo Código Civil de 2002.

A adoção da sociedade unipessoal pelo ordenamento brasileiro também depende de alterações legislativas, em especial no que se refere ao conceito de sociedade, fortemente influenciado pelos conceitos contratualistas clássicos. Porém, diante do que foi analisado, é, sim, perfeitamente possível e juridicamente justificável a existência de sociedade sem uma pluralidade de sócios, ademais dos benefícios econômicos advindos desse reconhecimento jurídico.

${ }^{165}$ MARCONDES MACHADO, Sylvio. Limitação de responsabilidade de comerciante individual. São Paulo: Max Limonad, 1956. p. 235. 
As críticas à unipessoalidade, como seu caráter potencialmente fraudulento $^{166}$, não se sustentam, pois é perfeitamente possível estruturar normas de proteção a terceiros, tais como existentes nas sociedades pluripessoais, e aplicar as sanções cabíveis em caso de descumprimento ${ }^{167}$.

Por sua inconteste superioridade, a fórmula societária tem sido adotada pela grande maioria dos países, como se passa a analisar.

\footnotetext{
${ }^{166}$ Lamartine Corrêa de Oliveira ressalta a frequência com que surgem precedentes de desconsideração da personalidade jurídica no campo das sociedades unipessoais e grupos de sociedades, e o justifica pela falta de autonomia de vida da sociedade e nítida separação entre as esferas patrimoniais e os interesses da sociedade e de seus membros. Em especial no caso da sociedade unipessoal, alega ser muito forte a tendência do sócio único a encarar a sociedade como mero instrumento de seus interesses. Ressalta que as formalidades legais não seriam aptas à preservação da separação entre sócio e sociedade.

Cf. OLIVEIRA, José Lamartine Corrêa de. A dupla crise da pessoa jurídica. São Paulo: Saraiva, 1979. p. 559.

${ }^{167}$ O tópico será desenvolvido no item 8.3.
} 


\section{A SOCIEDADE UNIPESSOAL NO DIREITO COMPARADO}

\subsection{União Europeia}

As sociedades de responsabilidade limitada com um único sócio foram reguladas no direito comunitário europeu ainda na vigência da Comunidade Econômica Europeia (CEE), em 1989, pela Décima Segunda Diretiva do Conselho (89/667/CEE).

Nas considerações iniciais da Diretiva, lê-se o seguinte:

"Considerando que, pela sua resolução de 3 de Novembro de 1986, o Conselho adotou, em 3 de Novembro de 1986, o programa de ação para as pequenas e médias empresas (PME);

Considerando que as reformas introduzidas em algumas legislações nacionais, no decurso dos últimos anos, com o objetivo de permitir a existência de sociedades de responsabilidade limitada com um único sócio, deram origem a disparidades entre as legislações dos Estadosmembros;

Considerando que é conveniente prever a criação de um instrumento jurídico que permita a limitação da responsabilidade do empresário individual, em toda a Comunidade, sem prejuízo das legislações dos Estados-membros que, em casos excepcionais, impõem a responsabilidade desse empresário relativamente às obrigações da empresa;

Considerando que uma sociedade de responsabilidade limitada pode ter um único sócio no momento da sua constituição, ou então por força da reunião de todas as partes sociais numa só pessoa; que, enquanto se aguarda a coordenação das disposições nacionais em matéria de direito dos grupos, os Estados-membros podem prever certas disposições especiais, ou sanções, aplicáveis no caso de uma pessoa singular ser o único sócio de diversas sociedades ou quando uma sociedade unipessoal ou qualquer outra pessoa coletiva for o único sócio de uma sociedade; que o único objetivo desta faculdade é atender às particularidades atualmente existentes em determinadas legislações nacionais; que os Estados-membros podem, para esse efeito, e em relação a casos específicos, prever restrições ao acesso à sociedade unipessoal ou a 
responsabilidade ilimitada do sócio único; que os Estados-membros são livres de estabelecer regras para enfrentar os riscos que a sociedade unipessoal pode apresentar devido à existência de um único sócio, designadamente para garantir a liberação do capital subscrito;

Considerando que a reunião de todas as partes sociais numa única pessoa, bem como a identidade do único sócio, devem ser objeto de publicidade de num registro acessível ao público;

Considerando que as decisões adotadas pelo sócio único, na qualidade de assembleia geral de sócios, devem assumir a forma escrita;

Considerando que a forma escrita deve ser igualmente exigida para os contratos celebrados entre o sócio único e a sociedade por ele representada, desde que esses contratos não digam respeito a operações correntes celebradas em condiçôes normais"

Logo no preâmbulo da Diretiva é possível vislumbrar a necessidade de adoção da sociedade com um só sócio, especialmente no que diz respeito às pequenas e médias empresas; mas também se verifica a preocupação do legislador em evitar as repercussões negativas que tal estrutura pode acarretar. Assim, a Diretiva procurou regular as relações internas e externas da sociedade unipessoal, primando pela publicidade e garantia dos credores.

A Diretiva é bastante sucinta, trazendo apenas aspectos fundamentais relativamente às sociedades unipessoais, quais sejam:

- possibilidade de constituição de sociedade com um só sócio (unipessoalidade originária) ou reunião de todas as partes sociais em uma única pessoa (unipessoalidade superveniente);

- possibilidade de adoção, pelos Estados-membros, de disposições especiais ou sanções no que diz respeito a (a) uma única pessoa natural ser sócia de mais de uma sociedade unipessoal; ou (b) uma sociedade unipessoal ou pessoa coletiva ser sócia única de uma sociedade.

- necessidade de divulgação em caso de unipessoalidade superveniente; 
- obrigatoriedade de adoção de forma escrita para as decisões tomadas pelo sócio único e para os contratos celebrados entre o sócio e a sociedade;

- possibilidade de o Estado-membro deixar de adotar as sociedades unipessoais caso sua legislação preveja a existência de empresas de responsabilidade limitada com patrimônio afetado à atividade e desde que, no que se refere a essas empresas, se prevejam garantias equivalentes às impostas às sociedades unipessoais ${ }^{168}$.

A Diretiva 89/667/CEE foi integralmente substituída pela Diretiva 2009/102/02 do Parlamento e Conselho Europeus de 16.09.2009, publicada no Diário Oficial da União Europeia em 01.10.2009, com efeitos a partir de 21.10.2009. A nova Diretiva apenas consolida as alterações sofridas pela Diretiva 89/667/CEE ao longo dos anos, em especial no que diz respeito aos países membros e tipos societários de cada um em que é possível a unipessoalidade.

As sociedades unipessoais na União Europeia foram adotadas, dentre outros $^{169}$, pelos seguintes Estados-membros:

Irlanda: European Communities (Single-Member Private Limited Companies) Regulations, 1994; European Communities (Single-Member Private Limited Companies) (Forms) Regulations, 1994.

Grécia: Décret présidentiel numéro 279/1993.

Espanha: Ley número 2/95 de 23.03.1995 de Sociedades de Responsabilidad Limitada.

França: Loi Numéro 85-697 du 11.07.1985 relative à l'entreprise unipersonnelle à responsabilité limitée et à l'exploitation agricole à responsabilité limitée; e Décret Numéro 88-909 du 30.076.1988.

\footnotetext{
${ }^{168}$ Como foi o caso de Portugal que, inicialmente, deixou de adotar as sociedades unipessoais, preferindo a separação patrimonial, por meio dos Estabelecimentos Individuais de Responsabilidade Limitada (EIRL). Posteriormente, porém, também aquele país passou a acolher a unipessoalidade societária. Para maior detalhamento vide item 6.3 .

${ }^{169}$ Bélgica, Bulgária, República Checa, Dinamarca, Alemanha, Estônia Chipre, Letônia, Lituânia, Hungria, Malta, Países Baixos, Áustria, Polônia, Romênia, Eslovênia, Eslováquia, Finlândia e Suécia.
} 
Itália: Decreto legislativo del 03.03.1993 nº 88, attuazione della direttiva 89/667/CEE in materia di diritto delle società relativa alla società a responsabilità limitata con un unico socio.

Luxemburgo: Loi du 28.12.1992 modifiant la loi du 10.08.1915 concernant les sociétés commerciales à l'effet d'introduire la société à responsabilité limitée unipersonnelle.

Portugal: Decreto-Lei n. 257/96 de 31.12.1996. Altera o Decreto-Lei n 262/86, de 2 de Setembro, que aprova o Código das Sociedades Comerciais, na redacção que lhe foi dada pelo Decreto-Lei n. 328/95, de 9 de Dezembro, o Código Comercial, o Decreto-Lei no 270/95, de 14 de Agosto, que aprova o Código do Notariado, o Decreto-Lei

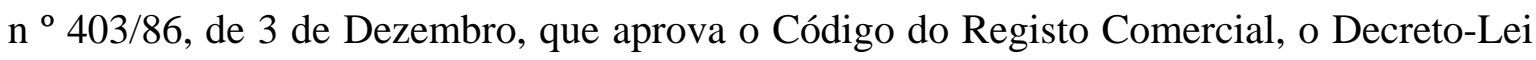
$n^{\circ} 42 / 89$, de 3 de Fevereiro, e a Portaria no 883/89, de 13 de Outubro, na redacção que lhe foi dada pela Portaria $n^{\circ} 773 / 94$, de 26 de Agosto.

Reino Unido: The Companies (Single Member Private Limited Companies) Regulations 1992; e The Companies (Single Member Private Limited Companies) Regulations (Northern Ireland) 1992.

Destes, passamos a analisar com maior profundidade os ordenamentos francês, português e espanhol.

\section{2. $O$ direito francês}

A partir de 1970 teve início na França um movimento no sentido de permitir a limitação de responsabilidade do comerciante individual. Diversos projetos de lei se sucederam nesse sentido, alguns visando à adoção da sociedade individual (ora como tipo societário sui generis, ora dentro do regime das sociedades limitadas), outros a técnica de patrimônio de afetação.

A legislação francesa foi muito fortemente influenciada pela concepção contratualista clássica, como se verifica da redação do antigo artigo 1.832 do Code Civil francês, que previa que "[l]a societé est un contrat par lequel deux ou pluisieurs personnes conviennent de mettre quelque chose em commun dans la vue de partager le bénéfice qui 
pourra em résulter."170 Assim, de maneira geral, o patrimônio de afetação tinha a preferência dos autores, por uma razão essencialmente dogmática: a sociedade, como grupo de pessoas por essência, não poderia ser unipessoal ${ }^{171}$.

Quando da discussão do rapport elaborado pelo Professor Claude Champaud (1978) para estudo da introdução da limitação de responsabilidade do empresário individual, o legislador local sustentava a superioridade da fórmula não societária, com o argumento de que era necessário evitar as ficções.

$\mathrm{O}$ projeto propunha a criação de trois masses actives et passives du patrimoine de l'entreprise: uma destinada à empresa (patrimoine affecté), que não poderia servir como garantia aos credores pessoais do sócio; a segunda não afetada à empresa, mas que poderia ser utilizada para as necessidades da empresa por iniciativa de credores insatisfeitos ou do próprio empresário (patrimoine disponible); e a terceira exclusiva do empresário, para sua sobrevivência e sustento, que não poderia ser dada em garantia aos credores da empresa, exceto no caso de falta grave cometida pelo empresário (patrimoine indisponible et insaisissable).

Ademais, o projeto previa a organização de um sistema de mutualização de riscos, pelo qual seria obrigatória a adesão a uma caixa de garantia comum aos empresários, para a qual todos deveriam contribuir (cotisations obligatoires).

Observam-se claramente os objetivos econômicos do projeto, ao instituir um patrimônio flexível para evitar eventuais abalos creditícios e eliminar privilégios aos credores com maior poder de barganha, que poderiam exigir garantias pessoais. Todavia, as cotas da tal caísse de garantie seriam transferíveis, não sendo, pois, uma garantia efetiva, vez que poderiam ser exigidas pelos credores mais fortes ${ }^{172}$.

\footnotetext{
${ }^{170}$ A primeira evolução legislativa, ainda que parcial, no sentido da admissão da sociedade unipessoal veio em 1966, com a lei de 24 de julho, que suprimiu a sanção de dissolução automática das sociedades comerciais tornadas unipessoais, as quais poderiam recompor a pluralidade de sócios no prazo de até um ano, após o qual, mantida a unipessoalidade, a sociedade poderia ser dissolvida apenas mediante pronunciamento judicial nesse sentido a pedido de interessados.

Essa solução foi estendida aos demais tipos sociais (i.e. sociedades civis) pela lei de 4 de janeiro de 1978, relativa às regras comuns a todas as sociedades, e permanece em vigor até hoje para os tipos societários para os quais a unipessoalidade não é reconhecida no ordenamento francês.

${ }^{171}$ DAIGRE, Jean-Jacques. "La societé unipersonnelle". In : Revue internationale de droit compare, v. 42, n. 2. Société de Législation Comparée: Paris, 1990. p. 669.

${ }^{172}$ SALOMÃO FILHO, Calixto. A sociedade unipessoal. São Paulo: Malheiros, 1995. p. 33.
} 
O projeto do grupo Champaud entendia desnecessária a atribuição de personalidade jurídica à empresa individual, vez entendiam que a personalização teria por objeto permitir a expressão de interesses comuns ligados à existência de um patrimônio coletivo. Isso acabaria por dificultar a transferência da empresa, já que, em regra, salvo previsão expressa no estatuto, a empresa seria liquidada com a morte de seu titular.

Demais disso, a cessão intervivos dar-se-ia apenas com relação à totalidade da empresa, e ainda assim considerada uma cessão de débito, atribuindo-se direito de oposição aos credores. Isso tudo reduz a liquidez da empresa, além de criar um sistema exageradamente complicado de separação patrimonial.

Ademais, o patrimônio de afetação imporia um formalismo comparável àquele das sociedades ${ }^{173}$. Por tais motivos, o projeto foi abandonado.

Com a promulgação da lei ${ }^{\circ}$ 85-697, de 11 de julho de 1985, cria-se na França a figura da Enterprise Unipersonnelle à Responsabilité Limitée (EURL). Não se trata de um novo tipo societário, mas sim da possibilidade de adoção, pela Société à Responsabilité Limitée (SARL) - e apenas por esta -, da forma unipessoal ${ }^{174}$.

Com o novo texto legislativo, o artigo 1.832 do Code Civil passou a vigorar com a seguinte redação:

"La société est instituée par deux ou plusieurs personnes qui conviennent par un contrat d'affecter à une entreprise commune des biens ou leur industrie en vue de partager le bénéfice ou de profiter de l'économie qui pourra en résulter.

Elle peut être instituée, dans les cas prévus par la loi, par l'acte de volonté d'une seule personne.

Les associés s'engagent à contribuer aux pertes." (Grifamos)

\footnotetext{
${ }^{173}$ DAIGRE, Jean-Jacques. "La societé unipersonnelle". In: Revue internationale de droit comparé, v. 42, n. 2. Société de Législation Comparée: Paris, 1990. p. 672.

${ }^{174}$ Code de Commerce, article L223-1: "La société à responsabilité limitée est instituée par une ou plusieurs personnes qui ne supportent les pertes qu'à concurrence de leurs apports."
} 
No caso da sociedade unipessoal, o sócio único, denominado associé unique, exerce os poderes atribuídos à assembleia de sócios. Assim, cabem a ele as deliberações ordinárias (nomeação e destituição de administradores, aprovação de acordos com a sociedade, aprovação das contas e destinação dos resultados, entre outras), as decisões extraordinárias de alteração de status (como aumento ou redução de capital, incorporação, fusão ou cisão da sociedade etc.) e as resoluções que necessitem de unanimidade na SARL (como alteração da nacionalidade) ${ }^{175}$.

O sócio único não pode delegar seus poderes e todas as decisões tomadas no exercício dos poderes típicos da assembleia devem ser registradas por escrito, sob pena de anulação a requerimento de qualquer interessado.

A sociedade unipessoal não pode ser sócia única de uma sociedade limitada, sob pena de dissolução da sociedade a pedido de qualquer interessado. Todavia, a partir da promulgação do Code de Commerce, em 2000, não há mais limitação para que a pessoa física participe de mais de uma sociedade limitada.

Os relatórios de gestão e as contas anuais devem ser aprovados no prazo de até seis meses contados do término do exercício social.

A Enterprise Unipersonnelle à Responsabilité Limitée pode, a qualquer tempo, tornar-se uma SARL pluripessoal ou mesmo se transformar em outro tipo societário, desde que observados os requisitos legais.

\subsection{O direito português}

Atualmente, em Portugal, existem três possibilidades para o exercício da atividade empresarial de forma individual: (a) o empresário em nome individual, em que não há separação patrimonial e a responsabilidade é ilimitada (à semelhança do que ocorre no Brasil); (b) o Estabelecimento Individual de Responsabilidade Limitada (EIRL), que permite ao empresário afetar apenas uma parte de seu patrimônio ao exercício da empresa; e (c) a sociedade unipessoal por quotas.

175 DAIGRE, Jean-Jacques. "La societé unipersonnelle". In: Revue internationale de droit comparé, v. 42, n. 2. Société de Législation Comparée: Paris, 1990, p. 674. 
Já em 1986 o legislador português previu a necessidade de limitar a responsabilidade do empresário em nome individual pelas dívidas contraídas na exploração de sua empresa. Todavia, foi rechaçada, de início, a possibilidade de adoção da limitação pela via societária (sociedade unipessoal), nada obstante o legislador ressaltar tratar-se da forma prevalente nos países europeus e de aceitação generalizada na doutrina e na prática.

\section{A justificativa apresentada era de que em Portugal "as coisas não se} apresentam do mesmo modo (...) entre outras razões, por fidelidade à ideia da sociedadecontrato" 176 .

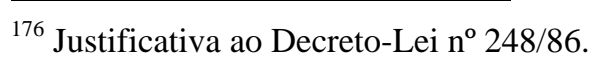

“(..)

3. De resto, a inovação legislativa de que se trata não representará um salto no desconhecido por parte do legislador português, antes tal actuação alinhará com a de outras legislações que, frequentemente, têm sido fonte de inspiração da nossa. Com efeito, razões idênticas ou próximas das atrás apontadas levaram a que, recentemente, na Alemanha (GmbH-Novelle de 1980) e na França (Lei n. ${ }^{\circ}$ 185-697, de 11 de Julho de 1985) fosse dada resposta legislativa favorável à pretensão do empresário individual de afectar ao giro mercantil unicamente uma parte do seu património.

A solução adoptada pelos legisladores alemão e francês - admissibilidade da criação ab initio da sociedade unipessoal de responsabilidade limitada - é, de facto, uma das duas vias possíveis para enquadrar juridicamente a situação em causa. A outra é representada pela criação de uma nova figura jurídica - a empresa (rectius: o estabelecimento) individual de responsabilidade limitada (com ou sem personalidade jurídica).

Qualquer destas soluções tem a seu favor e contra si vários argumentos.

Examine-se a primeira, que é a da sociedade unipessoal.

4. Consistirá esta na admissibilidade da constituição de uma sociedade comercial de responsabilidade limitada com um único sócio. Por ela enveredaram, como já foi dito, os legisladores alemão e francês. Certo que, tanto nos países europeus (mormente nos de cultura jurídica germânica) como em algumas nações latino-americanas, não se desconhece a específica problemática inerente à solução frontal da questão, ou seja, a admissão da figura do estabelecimento (empresa) mercantil individual de responsabilidade limitada. Pelo contrário, o assunto tem sido repetidamente objecto de profundas análises doutrinais e, até, de vários projectos legislativos.

No entanto, não foi essa a solução que prevaleceu nos referidos países. Porquê? (sic)

5. Foram duas, no essencial, as razões que levaram o legislador alemão a optar pela solução consagrada na GmbH-Novelle de 1980:

a) A grande difusão que a «Gesellsschaft mit beschrankter Haftung» unipessoal conhecia na prática: há longo tempo admitida pela doutrina e jurisprudência, o próprio legislador a tinha já reconhecido (assim, o $\S 15$ da Umwandlungsgesetz, de 6 de Novembro de 1986). Mas há mais. A praxis não legitimava apenas a sociedade de responsabilidade limitada que em certo momento, em virtude de vicissitudes normais da sua existência jurídica, ficara reduzida a um único sócio: ia bastante mais longe, pois coonestava as próprias sociedades ab initio constituídas por um único sócio verdadeiro, secundado (por via das aparências) por um ou mais testas-de-ferro (Strohmanner);

b) A maior facilidade em delinear um regime jurídico para esta situação: com efeito, a admissão da sociedade de responsabilidade limitada de um único sócio (Einmann-GmbH) apenas implicaria a adaptação de algumas normas do regime da $\mathrm{GmbH}$, ao passo que a outra opção - criação da empresa individual de responsabilidade limitada - levantaria muito mais graves dificuldades.

Assim se pensou e escreveu na Alemanha. 
Preferiu-se, em Portugal, inicialmente, a criação de um novo instituto jurídico, o Estabelecimento ${ }^{177}$ Individual de Responsabilidade Limitada (EIRL), "apesar da inovação que representa e das acrescidas dificuldades de regulamentação que determina".

Ao analisar se a disciplina legal do EIRL deveria assentar na construção como pessoa jurídica ou na ideia de patrimônio de afetação especial, o legislador português voltou-se ao pragmatismo, não reconhecendo ao ponto importância fundamental, uma vez que ambas as vias apontadas conduziriam a resultados satisfatórios.

Considerando-se que a atribuição de personalidade jurídica ao EIRL pareceu ao legislador "um processo mais complicado e, simultaneamente, mais artificial", e sendo o objetivo principal do instituto criar "um expediente técnico legal que permita ao

E não foram por certo diferentes das referidas as razões que pesaram no espírito do legislador francês e o levaram a admitir a constituição da sociedade de responsabilidade limitada com um único sócio (aliás, curiosamente, a lei em questão intitula-se «loi relative à l'entreprise unipersonnelle à responsabilité limitée»).

Assim procedendo, renunciou-se ao conceito tradicional da sociedade como contrato. Dogmaticamente, a sociedade é contrato e é instituição. Entretanto, as duas citadas leis pressupõem, ambas, uma construção dogmática em que aquela primeira componente (a ideia de contrato) é obliterada, ficando a sociedade reduzida à sua vertente institucional. E isto porque, bem atentas as (sic) coisas, e perspectivada agora a matéria a outra luz, a sociedade passa a ser preferentemente olhada como uma técnica de organização da empresa. O número daqueles que podem tirar proveito dessa técnica passa a não interessar. A sociedade de uma única pessoa não deixa de ser sociedade.

6. Quanto, porém, ao nosso país, as coisas não se apresentam do mesmo modo: as razões apontadas no número anterior não valem aqui com a mesma intensidade.

É certo que a ideia da sociedade com um único sócio encontra hoje aceitação generalizada tanto na doutrina como na prática, e até o novo Código das Sociedades Comerciais, vencidas algumas hesitações, lhe dará consagração igual àquela que um importante sector da doutrina nacional de há muito vinha preconizando.

Mas, em contrapartida, não deixa de ser verdade que entre nós (diferentemente do que acontece na Alemanha) nunca se admitiu - entre outras razões, por fidelidade à ideia da sociedade-contrato - a unipessoalidade originária. E não menos certo é, por outro lado, que (e também ao invés do que se passa naquele país) as contribuições doutrinais portuguesas sobre a regulamentação jurídica específica das sociedades de um único sócio são escassas. A hipótese configurada no artigo 488 daquele novo Código repercute um regime excepcional, que não altera esta forma de ver as coisas.

Eis porque, tudo pesado, não parece que a figura da sociedade unipessoal, nos latos termos em que passou a ser emitida no direito alemão e francês, seja em Portugal o instrumento jurídico mais apropriado para a solução do problema da limitação de responsabilidade do empresário individual. Mais lógico e mais conforme com os princípios tradicionais do nosso direito se apresenta o outro caminho apontado: a criação de um novo instituto jurídico - o estabelecimento mercantil individual de responsabilidade limitada. Esta se afigura ser a solução preferível, apesar da inovação que representa e das acrescidas dificuldades de regulamentação que determina."

177 Adotou-se a expressão "Estabelecimento", e não "Empresa”, pois o que se pretendeu autonomizar em relação ao patrimônio geral do titular não é a atividade (produção ou circulação de bens e a prestação de serviços), mas o estabelecimento comercial (conjunto organizado de meios pelos quais o empresário explora a sua atividade). 
comerciante em nome individual destacar do seu património geral uma parte dos seus bens, para destinar à actividade mercantil", se houve por bem conceber o EIRL como patrimônio separado, evitando a ficção.

Uma das grandes preocupações que nortearam o legislador quando da regulamentação jurídica do EIRL foi a garantia do interesse de terceiros que entram em relação com o estabelecimento. Neste sentido, o Decreto-Lei n ${ }^{\circ}$ 248/86 prevê a existência de normas que assegurem a efetiva realização do capital do estabelecimento e a fixação de um capital inicial mínimo, além de previsões quanto à adequada publicidade dos atos concernentes ao estabelecimento.

Demais disso, deve-se garantir a autonomia patrimonial dos bens destinados pelo empresário à empresa, respondendo tais bens exclusivamente pelas dívidas contraídas na exploração do EIRL e sem que os bens pessoais do empresário sejam afetados por dívidas decorrentes do exercício da atividade empresarial.

Finalmente, há normas no sentido de assegurar a efetividade da separação patrimonial, inclusive mediante manutenção de escrituração e contabilidade adequadas, respondendo o empresário individual com a totalidade dos seus bens caso se verifique qualquer violação a tal separação.

Ressalte-se que qualquer indivíduo que pretenda exercer atividade comercial pode constituir um Estabelecimento Individual de Responsabilidade Limitada, mas cada indivíduo só pode ser titular de um único EIRL.

O EIRL deve ser constituído por escrito e a firma é composta pelo nome do titular, acrescido ou não de referência ao objeto do comércio, e pelas palavras estabelecimento individual de responsabilidade limitada, ou simplesmente a sigla EIRL. O EIRL passa a ser eficaz perante terceiros a partir da publicação de seus atos constitutivos pela conservatória do registro competente.

O capital mínimo exigido é de $€ 5.000,00$ (cinco mil Euros), sendo ao menos 2/3 (dois terços) em dinheiro, e o restante em bens ou direitos suscetíveis de penhora. No momento do pedido de registro do EIRL, os bens e direitos integrantes do capital devem estar livres e desembaraçados de ônus, e a parcela em numerário deve estar 
depositada em instituição de crédito à ordem do titular do estabelecimento há menos de três meses. Esse valor só pode ser movimentado após o registro do EIRL.

Em todo e qualquer ato praticado pelo EIRL devem estar indicados claramente sua firma, sede, conservatória de registro, número de matrícula e número de identificação de pessoa coletiva.

A administração do EIRL compete a seu titular, e seu pró-labore, quando existir, não pode ser superior ao triplo do salário mínimo português.

O EIRL deve manter fundo de reserva, ao qual serão destinados, no mínimo, 20\% (vinte por cento) dos lucros anuais, até que o fundo represente metade do capital do estabelecimento. O fundo de reserva só pode ser utilizado: (a) para cobrir a parte do prejuízo acusado no balanço anual que não possa ser coberta pela utilização de outras reservas; (b) para cobrir a parte dos prejuízos transitados do exercício anterior que não possa ser coberta pelo lucro do exercício nem pela utilização de outras reservas; e (c) para incorporação ao capital.

A circulação e liquidez do EIRL são problemáticas, pois, caso o titular venha a falecer e os herdeiros deixarem de dar destinação ao estabelecimento no prazo de 90 dias, qualquer um pode requerer sua liquidação. E na transferência intervivos só é possível a cessão total.

No mais, o estabelecimento individual de responsabilidade limitada tem regramento bastante próximo às regras societárias, com exigência de formalidades similares e normas sobre integralização, modificação e proteção do capital social.

Em 1996, o legislador português reconheceu que a criação do estabelecimento individual de responsabilidade limitada não atingiu os resultados esperados, quais sejam, facilitar o aparecimento e, sobretudo, o desenvolvimento de pequenas empresas. Convencido da superioridade das sociedades unipessoais por quotas, o legislador português as introduziu no ordenamento por meio dos artigos 270-A a 270-F do Código das Sociedades Comerciais (Decreto-Lei no $262 / 86)^{178}$.

$\overline{{ }^{178} \text { Introduzidos pelo Decreto-Lei no }}$ 257/96. 
O legislador deixa claro o equívoco em não ter sido adotada antes a limitação de responsabilidade pela forma societária na justificativa do Decreto-Lei no 257/96:

“As sociedades de responsabilidade limitada são a forma por excelência escolhida pelas pequenas e médias empresas. É clara entre nós a propensão dos empresários para a utilização deste tipo de sociedades como forma de enquadramento jurídico das suas empresas. As sociedades unipessoais por quotas existem em quase todos os Estados membros da Comunidade Europeia, já por razões jurídicas, já por razões económicas. Importa introduzi-las no nosso direito das sociedades.

$N a$ verdade, estas sociedades podem facilitar o aparecimento $e$, sobretudo, o são desenvolvimento de pequenas empresas, que, como é reconhecido, constituem, principalmente em épocas de crise, um factor não só de estabilidade e de criação de emprego mas também de revitalização da iniciativa privada e da actividade económica em geral. Permitem, efectivamente, que os empreendedores se dediquem, sem recurso a sociedades fictícias indesejáveis, à actividade comercial, beneficiando do regime da responsabilidade limitada.

A criação do estabelecimento individual de responsabilidade limitada pelo Decreto-Lei $n^{\circ}$ 248/86, de 25 de Agosto, não atingiu esses resultados. Fiel à doutrina tradicional, o legislador de então não conseguiu ultrapassar a concepção contratualista da sociedade e por isso rejeitou qualquer concessão à sua concepção institucional. Quedouse pela constituição de um património autónomo afectado a um fim determinado, mas desprovido dos benefícios da personalidade jurídica. Afastou-se expressamente das soluções já nessa altura adoptadas pela Alemanha e pela França. Portugal tornou-se o único Estado membro da Comunidade Europeia a optar pela via do estabelecimento individual de responsabilidade limitada. Teve-se como indiscutivel que a sociedade unipessoal não era instrumento apropriado à realidade do nosso país $e$ daí enveredar-se por uma pretensa e difícil inovação. Negou-se a personalização a algo que a reclamava. 
É certo que a instituição das sociedades unipessoais por quotas levantou inicialmente delicados problemas doutrinais. Não faltou quem considerasse um "absurdo" a existência legal de sociedades unipessoais. Essa dificuldade recebeu uma resposta teórica, em que a sociedade unipessoal constituiria a excepção à regra das sociedades pluripessoais. Mas importa sobretudo facultar às pessoas uma forma de limitação da sua responsabilidade que não passe pela constituição de sociedades fictícias, com "sócios de favor", dando azo a situações pouco claras no tecido empresarial.

Foi esta realidade que justificou a Directiva $n .^{\circ} 89 / 667 / C E$, bem como as alterações legislativas ocorridas, designadamente em Espanha com a Lei 2/1995, de 23 de Março, em França com a Lei n. ${ }^{o}$ 85/697, de 11 de Julho, na Itália com o Decreto Legislativo $n^{\circ}$ 88, de 3 de Março de 1993, e na Bélgica com a Lei de 14 de Julho de 1987.

É ainda o reconhecimento dessa realidade que serve de primacial fundamento à presente institucionalização. Impõe-se, pois, sem abjurar, de momento, nenhuma das figuras legalmente estabelecidas, criar um novo tipo de sociedade, em que a responsabilidade do sócio único seja limitada. Sobretudo em relação às pequenas e médias empresas, esperase que este novo tipo de sociedade constitua mais uma escolha que facilite a sua legalização e uma adaptação maior ao importante papel que desempenham no tecido económico nacional.

Daí que a criação de sociedades unipessoais por quotas possa ser originária ou superveniente. Não se acolhe, nesta fase inicial, a possibilidade, que a prática imporá ou não, da criação autónoma e por tempo indeterminado da sociedade anónima unipessoal.

Para a cabal prossecução dos objectivos enunciados, foram consagrados alguns princípios de segurança, tanto do sócio único como de terceiros.

Foram também tidas em conta as injunções da referida directiva e a necessidade de prosseguir na via da harmonização das legislações dos Estados membros da União Europeia." 
De acordo com o Código das Sociedades Comerciais, no direito luso a sociedade unipessoal pode ser formada por sócio pessoa física ou pessoa jurídica, sendo a unipessoalidade originária ou superveniente (concentração na titularidade de um único sócio das quotas de uma sociedade por quotas). A transformação de sociedade coletiva em sociedade singular dá-se por mera declaração do sócio remanescente, que pode constar do próprio instrumento de cessão de quotas.

Aplicam-se de forma subsidiária às sociedades unipessoais todas as disposições relativas às sociedades coletivas, exceto, por óbvio, aquelas que pressuponham a pluralidade de sócios.

Os Estabelecimentos Individuais de Responsabilidade Limitada podem, a qualquer tempo, transformar-se em sociedade unipessoal, mediante declaração escrita do empresário.

A firma ${ }^{179}$ das sociedades unipessoais deve vir sempre acompanhada da expressão "sociedade unipessoal" ou da palavra "unipessoal”.

Cada pessoa singular só pode ser sócia de uma sociedade unipessoal por quotas, e a sociedade unipessoal por quotas não pode participar do capital de outra sociedade unipessoal, sob pena de dissolução da sociedade. A dissolução pode ser requerida por qualquer interessado e se dá pela via administrativa.

Existe, a todo tempo, a possibilidade de admitir-se novos sócios, transformando-se a sociedade unipessoal em coletiva, com a eliminação da firma da indicação da unipessoalidade.

O sócio único na sociedade unipessoal exerce as competências da assembleia geral, podendo, inclusive, nomear gerentes. Todas as decisões do sócio de natureza equivalente às deliberações assembleares devem ser registradas por escrito em ata por ele assinada.

São admitidos negócios entre a sociedade e o sócio único, desde que sirvam à persecução do objeto da sociedade e obedeçam à forma escrita (sempre) e demais

\footnotetext{
${ }^{179}$ Nos termos do artigo 10 do Código das Sociedades Comerciais português, a firma da sociedade pode ser composta por nomes ou firmas de todos, algum ou alguns sócios, denominação particular ou denominação e nome ou firma de sócio.
} 
formalidades legais, se for o caso. Tais documentos, assim como o relatório de gestão e documentos de prestação de contas, devem ser arquivados a sede da sociedade e disponibilizados para consulta de qualquer interessado, a todo tempo. A violação a quaisquer dos requisitos implica na nulidade dos negócios jurídicos celebrados entre sócio e sociedade e acarretam responsabilização de forma ilimitada do sócio.

\subsection{O direito espanhol}

$\mathrm{Na}$ Espanha, os conceitos expressos no artigo 116 do Código de Comércio $^{180}$ e no artigo 1.665 do Código Civil ${ }^{181}$ não admitiam a possibilidade de sociedade com um único sócio. Contudo, o Tribunal Supremo e a Dirección General de Registros já revelavam sua inclinação favorável à unipessoalidade ${ }^{182}$, o que foi reconhecido, ex leges, por meio de resolução da Dirección General de Registros y del Notariado, datada de 21.12.1990.

Em atenção ao quanto determinado na $12^{\mathrm{a}}$ Diretiva da Comunidade Europeia (89/667), a Espanha incorporou em definitivo a sociedade unipessoal em seu ordenamento por meio da Ley $\mathrm{n}^{\mathbf{0}} 2$, de 23.03.1995, ampliando sua possibilidade de aplicação não só às pequenas e médias empresas, como determinado pela Diretiva, mas também às grandes corporações.

A norma espanhola permite a existência de sociedades unipessoais originárias e supervenientes ${ }^{183}$. A sociedade unipessoal é considerada originária quando “constituida por un único socio", sendo este tanto pessoa física quanto jurídica. Já a unipessoalidade superveniente decorre da sociedade que foi "constituida de manera

\footnotetext{
${ }^{180}$ Real Decreto de Publicación de 02.08.1885, Art. 116: "El contracto de compañía, por lo cual dos o más personas se obligan a poner en fondo común bienes, industria o alguna de estas cosas, para obtener lucro, será mercantil, cualquiera que fuese su clase, siempre que se haya constituido con arreglo a las disposiciones de este Código. Una vez constituida la compañía mercantil, tendrá personalidad jurídica en todos sus actos y contratos."

${ }^{181}$ Real Decreto de Publicación de 24.07.1889, Art. 1.665: "La sociedad es un contrato por el cual dos o más personas se obligan a poner en común dinero, bienes o industria, con ánimo de partir entre si las ganancias."

${ }^{182}$ STS 19-4-1960; Res. DGRN 13 y 14-11-1985.

${ }^{183}$ Art. 125 da Lei $n^{\circ}$ 2/1995.
} 
plurilateral y acaba concentrando todas sus participaciones en las manos de un único propietario".

Para resguardar direitos de terceiros, no caso de conversão de sociedade pluripessoal é necessário observar a regra do Artigo 129 da Ley n 2/1995, que determina a necessidade de registro da nova situação de unipessoalidade no Registro Mercantil, mediante escritura pública ${ }^{184}$.

Apesar de sua natureza distinta, a constituição da sociedade unipessoal deve observar a regra geral do artigo 11.1 da Ley $\mathrm{n}^{\circ}$ 2/1995, qual seja, constar de escritura pública inscrita no Registro Mercantil. Para tanto, devem ser observados os mesmos critérios para constituição das sociedades pluripessoais, no que diz respeito à capacidade das partes e objeto da empresa.

A sociedade unipessoal se submete a um regime de publicidade dos atos mais amplo do que aquele que rege as demais sociedades. Qualquer alteração relativa ao corpo social deve ser efetuada por meio de escritura pública arquivada no Registro Mercantil e a identidade do sócio único sempre deve ser revelada ${ }^{185}$.

A sociedade unipessoal pode ter a forma de anônima ou limitada, porém todos os atos praticados pela sociedade devem trazer claramente sua condição de unipessoalidade, mediante indicação expressa em seus documentos ${ }^{186}$.

O sócio único exerce todas as competências atribuídas pela legislação espanhola à Junta General $^{187}$, devendo as decisões serem tomadas por escrito em ata e executadas pelo próprio sócio ou pelos administradores da sociedade.

${ }^{184}$ CHULIA, Francisco Vicent. Introducción al derecho mercantil. Valencia: Tirant lo blanc, 1999. p. 420.

${ }^{185}$ Ley $\mathrm{n}^{\circ}$ 2/1995, art. 126, inc. 1: "La constitución de una sociedad unipersonal de responsabilidad limitada, la declaración de tal situación como consecuencia de haber pasado un único socio a ser propietario de todas las participaciones sociales, la perdida de tal situación o el cambio del socio único como consecuencia de haberse transmitido alguna o todas las participaciones, se harán constar en escritura pública que se inscribirá en el Registro Mercantil. En la inscripción se expresará necesariamente la identidad del socio único."

${ }^{186}{ }^{2}$ ey $\mathrm{n}^{\circ}$ 2/1995, art. 126, inc. 2: "En tanto subsista la situación de unipersonalidad, la sociedad hará constar expresamente su condición de unipersonal en toda su documentación, correspondencia, notas de pedido y facturas, así como en todos anuncios que haya de publicar por disposición legal o estatutaria."

${ }^{187}$ Ley no $^{\circ}$ 2/1995, art. 44: "1. Es competencia de la Junta General deliberar y acordar sobre los siguientes asuntos:

a. La censura de la gestión social, la aprobación de las cuentas anuales y la aplicación del resultado. 
Finalmente, o artigo 128 da Ley $n^{\circ}$ 2/1995 dispõe sobre a celebração de contratos entre o sócio e a sociedade, determinando que os contratos devem ser executados por escrito ou na forma documental exigida por sua natureza, e transcritos em livro próprio. Tais contratos devem, ainda, ser expressa e individualmente indicados nos balanços da sociedade, constando sua natureza e condições.

Pretendeu, pois, o legislador dar ampla publicidade destes documentos àqueles que venham a contratar com a sociedade. Contudo, a obrigatoriedade de revelar as condições do contrato pode beneficiar eventuais concorrentes da sociedade, que terão acesso ao seu conteúdo.

Os contratos que não tenham sido transcritos no livro próprio ou que não constem do balanço anual não são oponíveis à massa em caso de insolvência ou falência da sociedade. Ademais, o sócio responde perante a sociedade por todas as vantagens que tenha obtido, direta ou indiretamente, em virtude da celebração de tais contratos e que causem prejuízos àquela, pelo prazo de dez anos contados da data de celebração do contrato.

Pela análise da evolução legislativa no direito comparado verifica-se, portanto, que a sociedade unipessoal perdeu seu caráter de impropriedade terminológica e passou a ser vista como uma consequência do caráter organizativo das sociedades, da estruturação de um ente dirigido à consecução de determinado objetivo. A sociedade passa a ser a organização de capital e trabalho para atender às necessidades do mercado, o que independe do simples agrupamento de pessoas.

b. El nombramiento y separación de los administradores, liquidadores y, en su caso, de los auditores de cuentas, así como el ejercicio de la acción social de responsabilidad contra cualquiera de ellos.

c. La autorización a los administradores para el ejercicio, por cuenta propia o ajena, del mismo, análogo o complementario género de actividad que constituya el objeto social.

d. La modificación de los estatutos sociales.

e. El aumento y la reducción del capital social.

f. La transformación, fusión y escisión de la sociedad.

g. La disolución de la sociedad.

h. Cualesquiera otros asuntos que determinen la Ley o los estatutos.

2. Además, y salvo disposición contraria de los estatutos, la Junta General podrá impartir instrucciones al órgano de administración o someter a autorización la adopción por dicho órgano de decisiones o acuerdos sobre determinados asuntos de gestión, sin perjuicio de lo establecido en el artículo 63." 
Comprova-se, assim, que a via societária da limitação de responsabilidade do empresário individual é não só possível, mas plenamente viável, desde que corretamente reguladas suas relações internas e externas e devidamente protegidos os direitos e interesses de terceiros. 


\section{A POSIÇÃO NO BRASIL}

A sociedade unipessoal, no Brasil, jamais foi pensada como um modelo legal, mas sempre como hipótese inaceitável, vez que contrária ao corolário necessário e inexorável da pluralidade de associados ${ }^{188}$.

Isso porque o sistema societário brasileiro é permeado por princípios contratualistas. A própria definição de sociedade, tanto no Código Civil de 1916 como no codex atual, é um exemplo disso:

CC 1916, Art. 1.362: "Celebram contrato de sociedade as pessoas que mutuamente se obrigam a combinar seus esforços e recursos, para lograr fim comum."

CC 2002, Art. 981: "Celebram contrato de sociedade as pessoas que reciprocamente se obrigam a contribuir, com bens ou serviços, para o exercício de atividade econômica e a partilha, entre si, dos resultados."

Verifica-se claramente a referência à pluralidade de sócios ("celebram contrato de sociedade as pessoas"), à concentração em torno de uma mesma finalidade ("para lograr fim comum"; "para o exercício de atividade econômica e a partilha, entre si, dos resultados") e à existência de obrigações entre os sócios, mas não dos sócios para com a sociedade ("mutuamente se obrigam a combinar"; "reciprocamente se obrigam a contribuir").

\subsection{A subsidiária integral}

Com o advento da Lei das Sociedades por Ações (LSA), em 1976, o legislador procurou incentivar a macroempresa e a capitalização via mercado, introduzindo na regulamentação societária princípios institucionalistas:

Art. 116, § único: “O acionista controlador deve usar o poder com o fim de fazer a companhia realizar o seu objeto e cumprir sua função social, e tem deveres e responsabilidades para com os demais acionistas da

\footnotetext{
${ }^{188}$ PRADO FILHO, José Inácio Ferraz de Almeida. "Notas sobre as sociedades fictícias, ou de favor". In: Revista de Direito Mercantil Industrial, Econômico e Financeiro, v 134, 2004. pp. 85-86.
} 
empresa, os que nela trabalham e para com a comunidade em que atua, cujos direitos e interesses deve lealmente respeitar e atender."

Art. 117, §1º alíneas "b" e "c": "São modalidades de exercício abusivo de poder:

b) promover a liquidação de companhia próspera, ou a transformação, incorporação, fusão ou cisão da companhia, com o fim de obter, para si ou para outrem, vantagem indevida, em prejuízo dos demais acionistas, dos que trabalham na empresa ou dos investidores em valores mobiliários emitidos pela companhia;

c) promover alteração estatutária, emissão de valores mobiliários ou adoção de políticas ou decisões que não tenham por fim o interesse da companhia e visem a causar prejuízo a acionistas minoritários, aos que trabalham na empresa ou aos investidores em valores mobiliários emitidos pela companhia;"

Art. 154, $\S 4^{\circ}$ : "O conselho de administração ou a diretoria podem autorizar a prática de atos gratuitos razoáveis em benefício dos empregados ou da comunidade de que participe a empresa, tendo em vista suas responsabilidades sociais."

A relação entre grandes empresas e princípios institucionalistas ${ }^{189}$ justificou a admissão da sociedade unipessoal dentro dos grupos de fato, como exceção à regra de pluralidade de sócios para constituição da empresa (LSA, Art. 80, I) e à necessária dissolução da sociedade reduzida a um só sócio (LSA, Art. 206, I, “d”). Surge, assim, a figura da subsidiária integral ${ }^{190}$, regulada nos artigos 251 a 253 da LSA.

\footnotetext{
${ }^{189} \mathrm{O}$ institucionalismo trazido pela legislação acionária está limitado à mera declaração de princípios, pois a legitimidade para demandar os responsáveis pela prática de atos contrários ao interesse social é exclusiva dos sócios.

${ }^{190}$ Calixto Salomão Filho critica, contudo, a falta de regulamentação específica relativa à responsabilidade, ao conflito de interesses ou à publicidade para a sociedade unipessoal de grupo, "como se o legislador acreditasse na persecução espontânea do interesse social por parte do sócio único, sem um sistema legal que o constranja a tal". Cf. SALOMÃO FILHO, Calixto. A sociedade unipessoal. São Paulo: Malheiros, 1995. p. 57.
} 
Nos termos do artigo 251 da LSA, a companhia pode ser constituída, mediante escritura pública, tendo como único acionista uma sociedade brasileira. Pode também a companhia ser convertida em subsidiária integral, mediante aquisição, por sociedade brasileira, de todas as suas ações ou incorporação da totalidade das ações de uma companhia ao patrimônio de outra companhia.

Por tratar-se de lei especial, não é possível estender a unipessoalidade da subsidiária integral a outros tipos societários que não a sociedade anônima.

\subsection{Unipessoalidade temporária}

Aparte a subsidiária integral, existe, no ordenamento brasileiro, outra forma prevista de unipessoalidade, qual seja a da sociedade reduzida a um único sócio.

Tal fato pode resultar da liquidação de quotas decorrente da morte de um dos sócios ${ }^{191}$; da exclusão judicial ou de pleno direito de sócio ${ }^{192}$; da saída em razão de dissidência ${ }^{193}$; ou, ainda, da retirada imotivada, nas hipóteses legais ${ }^{194}$.

Trata-se, no caso, de permissão expressa do legislador para que a sociedade permaneça, por prazo determinado ${ }^{195}$, com um único sócio até que se restabeleça a pluralidade. Caso não sejam admitidos novos sócios, a sociedade se dissolve de pleno direito $^{196}$.

\footnotetext{
${ }^{191}$ Código Civil, Art. 1.028.

${ }^{192}$ Código Civil, Art. 1.004, § único, Art. 1.030 e $\S$ único e Art. 1.085.

${ }^{193}$ Código Civil, Art. 1.077.
}

${ }^{194}$ Código Civil, Art. 1.029. A aplicabilidade do artigo em questão às sociedades limitadas é controversa, haja vista a existência, no âmbito das limitadas, de previsão expressa quanto à retirada apenas em casos de dissidência (art. 1.077).

195 Até a Assembleia Geral Ordinária subsequente, quando constatada a unipessoalidade em sociedades anônimas, ou no prazo de 180 dias, no caso das demais sociedades personificadas.

O prazo inicial da contagem dos 180 dias não foi estabelecido de forma expressa no Código Civil, mas a doutrina tende a entender como data de início da contagem a data em que o número de sócios se reduziu a um. Cf. VERÇOSA, Haroldo Malheiros Duclerc. Curso de direito comercial: teoria das sociedades, as sociedades em espécie do código civil. São Paulo: Malheiros, 2006. v. 2. p. 45.

${ }^{196}$ Nesse sentido:

Nas sociedades simples:

Código Civil, Art. 1.033. "Dissolve-se a sociedade quando ocorrer: 
Contudo, como nos informa Thelma de Mesquita Garcia e Souza ${ }^{197}$, há registro de decisões em que o Judiciário é condescendente e permite a continuação da sociedade com um só sócio, por tempo indeterminado e responsabilidade limitada, por aplicação do princípio da preservação da empresa. Tal posicionamento demonstra que o ambiente jurídico pátrio é propenso a admitir a sociedade unipessoal como forma de limitar a responsabilidade do comerciante individual.

\subsection{Projetos de lei}

\subsubsection{Anteprojeto de Lei de Sociedades de Responsabilidade Limitada}

O Anteprojeto de Lei de Sociedades de Responsabilidade Limitada, desenvolvido por comissão nomeada pelo Ministro da Justiça em 1999, presidida por Arnoldo Wald e com relatoria de Jorge Lobo ${ }^{198}$, previa, em seu capítulo IX, a introdução

\section{(...)}

IV - a falta de pluralidade de sócios, não reconstituída no prazo de cento e oitenta dias;

(...)"

Nas sociedades em nome coletivo:

Código Civil, Art. 1.044. "A sociedade se dissolve de pleno direito por qualquer das causas enumeradas no art. 1.033 e, se empresária, também pela declaração da falência."

Nas sociedades em comandita simples:

Código Civil, Art. 1.051. "Dissolve-se de pleno direito a sociedade:

I - por qualquer das causas previstas no art. 1.044;

$(\ldots) "$

Nas sociedades limitadas:

Código Civil, Art. 1.087. "A sociedade dissolve-se, de pleno direito, por qualquer das causas previstas no art. 1.044."

Nas sociedades anônimas:

LSA, Art. 206. "Dissolve-se a companhia:

(...)

d) pela existência de um único acionista, verificada em assembleia geral ordinária, se o mínimo de dois não for reconstituído até à do ano seguinte, ressalvado o disposto no artigo 251;

$(\ldots) "$

197 SOUZA, Thelma de Mesquita Garcia e, "Sociedade unipessoal como solução organizativa da empresa", in FRANÇA, Erasmo Valladão Azevedo e Novaes (org.), Direito Societário Contemporâneo I, São Paulo: Quartier Latin, 2009, p. 507.

198 A comissão contava ainda com os juristas César Asfor Rocha, Alfredo Lamy Filho, Egberto Lacerda Teixeira e Waldírio Bulgarelli. 
no ordenamento brasileiro da empresa individual de responsabilidade limitada, sob a forma de sociedade.

Abrangendo tanto a unipessoalidade originária quanto a superveniente, trazia o Anteprojeto, quanto a esta, a obrigatoriedade de comunicação por escrito aos credores no prazo de 30 dias da transformação, sob pena de responsabilização pessoal do sócio.

Demais disso, cada pessoa, física ou jurídica, poderia participar de uma única empresa individual de responsabilidade limitada, devendo, ainda, em todos os atos e negócios jurídicos praticados, deixar clara a situação de unipessoalidade da sociedade.

Ainda de acordo com a proposta apresentada, todas as decisões sociais deveriam ser transcritas em livro próprio e arquivadas no registro competente, sendo vedada a contratação, pela sociedade, com o sócio único, mesmo que em condições equitativas.

Este projeto foi, no entanto, atravessado pela alteração do Código Civil em 2002, que manteve a obrigatória pluralidade de membros para a constituição de sociedade.

\subsubsection{Projetos posteriores ao CC 2002}

Desde a promulgação do Código Civil de 2002, foram apresentados diversos projetos de lei visando à inclusão, no ordenamento, da sociedade unipessoal.

O primeiro deles, proposto pelo Deputado Almir Moura (PL/RJ), de n ${ }^{\circ}$ 2730/2003, previa a inclusão, no Livro II (Do Direito da Empresa), Capítulo II (Da Sociedade) do Código Civil, do artigo 985-A, com a seguinte redação:

“Art. 985-A. A sociedade unipessoal será constituída por um único sócio, pessoa singular ou coletiva, que é o titular da totalidade do capital social.

$\S 1^{o}$ A sociedade unipessoal também poderá resultar da concentração das quotas da sociedade num único sócio, independentemente da causa da concentração. 
$\S 2^{o}$ A firma da sociedade deverá ser formada pela expressão "Sociedade Unipessoal" ou "Unipessoal" antes da palavra "Limitada" ou da abreviatura "Ltda.".

$\S 3^{\circ}$ Somente o patrimônio social responderá pelas dívidas da sociedade unipessoal."

Verifica-se que o legislador não se preocupou em prever maiores regras ou garantias relativas ao instituto. De todo modo, a proposição foi arquivada em razão do término da legislatura.

Por ocasião do Projeto de Lei Complementar n 123, apresentado em 2004 pelo Deputado Jutahy Junior (PSDB/BA), posteriormente convertido na Lei Complementar $n^{\circ}$ 123/2006 (que institui o Estatuto Nacional da Microempresa e da Empresa de Pequeno Porte), havia, no artigo 69, previsão de limitação de responsabilidade do empresário enquadrado como microempresa ou empresa de pequeno porte aos bens e direitos vinculados à atividade empresarial $^{199}$.

Tal artigo foi, contudo, vetado ${ }^{200}$, sob justificativa de que:

“Na relação tributária, que é o que interessa para o presente estudo, verifica-se, logo em uma primeira análise, a ocorrência de afronta ao texto constitucional.

Com efeito, dispõe o art. 146, II, a, in fine, da Constituição Federal de 1988 que cabe à Lei Complementar 'estabelecer normas gerais em matéria de legislação tributária, especialmente sobre (...) contribuintes'.

Ora, o Código Tributário Nacional, que regulou toda a matéria relativa à responsabilidade tributária (arts. 128 a 138), restou recepcionado com eficácia passiva de Lei Complementar, atendendo, pois, ao comando acima transcrito.

\footnotetext{
199 Art. 69. "Relativamente ao empresário enquadrado como microempresa ou empresa de pequeno porte nos termos desta Lei Complementar, aquele somente responderá pelas dividas empresariais com os bens e direitos vinculados à atividade empresarial, exceto nos casos de desvio de finalidade, de confusão patrimonial e obrigações trabalhistas, em que a responsabilidade será integral."

${ }^{200}$ Mensagem n ${ }^{\circ}$ 1.098, de 14 de dezembro de 2006.
} 
Não se pode, agora, por meio de norma que sequer tem como objeto principal dispor acerca de normas gerais em matéria tributária, alterar a disciplina já instituída pelo CTN. Tal pretensão afigura-se de todo inoportuna, podendo ser até coimada de inconstitucional."

Todavia, nas razões de veto é salientado que:

"Os debates no Ministério da Fazenda levaram à conclusão de que é possível consagrar, por meio de adequadas alterações normativas, a responsabilidade limitada para o empresário individual. (...) Não se vislumbra óbices, todavia, a que o Governo aprofunde os estudos sobre o tema e, oportunamente, apresente uma proposta que contemple as alterações normativas adequadas para o fim desejado".

Ainda em 2004, foi apresentado pelo Deputado Luiz Carlos Hauly (PSDB/PR) o Projeto de Lei no 3667/2004. A proposição prevê uma série de alterações relativamente às sociedades limitadas e ao procedimento de ação judicial de dissolução de sociedades no que tange às micro e pequenas empresas. Todavia no que diz respeito às sociedades unipessoais, prevê simplesmente que "[a] sociedade limitada pode ser constituída e existir regularmente por um único sócio, que seja pessoa física residente no País." E, adicionalmente, que "[e]ste dispositivo aplica-se às sociedades simples (arts. 997 a 1.038 da Lei no 10.406, de 10 de janeiro de 2002, Código Civil) e de advogados (arts. 15 a 17 da Lei $n^{\circ}$ 8.906, de 4 de julho de 1994, Estatuto da Advocacia)”, ampliando, assim, a unipessoalidade ao âmbito das sociedades de cunho não empresário.

Novamente, não houve qualquer preocupação com relação à necessária regulamentação da inovação legislativa.

Em substitutivo apresentado pelo Deputado Mendes Ribeiro Filho (PMDB/RS), relator da Comissão de Constituição e Justiça e de Cidadania, no entanto, a previsão relativa à sociedade unipessoal foi excluída, sob a seguinte justificativa:

"Finalmente, assinale-se que a norma do projeto de lei em análise que prevê a introdução da sociedade unipessoal em nosso ordenamento jurídico não merece ser acolhida, uma vez que não convém estipular uma ficção legal tamanha que abandone por completo a natureza jurídica das sociedades, que sabidamente pressupõem a existência de 
duas ou mais pessoas que reciprocamente se obrigam a contribuir com bens ou serviços para o exercício de uma atividade econômica e a partilhar, entre si, os resultados advindos e o patrimônio." (Grifamos)

O parecer reflete bem a visão dos legisladores pátrios, ainda arraigada aos princípios contratualistas clássicos.

Finalmente, em 2009, foi apresentado pelo Deputado Marcos Montes (DEM/MG) o Projeto de Lei $n^{o} 4.605 / 2009$, que aguarda designação de relator na Comissão de Constituição e Justiça e de Cidadania.

Mais uma vez procurou-se incluir, no Código Civil, dispositivo objetivando a introdução no ordenamento da sociedade unipessoal, sob denominação de Empresa Individual de Responsabilidade Limitada, tendo sido proposta a seguinte redação:

"Art. 985-A. A empresa individual de responsabilidade limitada será constituída por um único sócio, pessoa natural, que é o titular da totalidade do capital social e que somente poderá figurar numa única empresa dessa modalidade.

$\S 1^{\circ}$ A empresa individual de responsabilidade limitada também poderá resultar da concentração das quotas de outra modalidade societária num único sócio, independentemente das razões que motivaram tal concentração.

$\S 2^{\circ}$ A firma da empresa individual de responsabilidade limitada deverá ser formada pela inclusão da expressão "EIRL" após a razão social da empresa.

$\S 3^{\circ}$ Somente o patrimônio social da empresa responderá pelas dívidas da empresa individual de responsabilidade limitada, não se confundindo em qualquer situação com o patrimônio pessoal do empresário, conforme descrito em sua declaração anual de bens entregue à Secretaria da Receita Federal do Ministério da Fazenda.

$\S 4^{o}$ Aplicam-se à empresa individual de responsabilidade limitada os dispositivos relativos à sociedade limitada, previstos nos arts. 1.052 a 1.087 desta lei, naquilo que couber e não conflitar com a natureza jurídica desta modalidade empresarial." 
Como se vê, o projeto é incompleto e não trata de questões essenciais, tais quais a necessidade de ampla publicidade da situação de unipessoalidade e o tratamento do capital social. Demais disso, apesar de incluir a empresa individual de responsabilidade limitada no título das sociedades, não altera o conceito desta, disposto no artigo 981, que exige a convergência de vontades.

A este Projeto de Lei foi apensado outro, de $n^{\circ} 4.953 / 2009$, de autoria do Deputado Eduardo Sciarra (DEM/PR), que prevê a criação de uma nova pessoa jurídica de direito privado, o Empreendimento Individual de Responsabilidade Limitada.

Segundo o projeto em questão, além da inclusão do Empreendimento Individual de Responsabilidade Limitada no rol do artigo 44 do Código Civil, seria incluído um novo capítulo no Livro II do Código, com a seguinte redação:

\author{
“CAPÍTULO III \\ DOS EMPREENDIMENTOS INDIVIDUAIS DE RESPONSABILIDADE \\ LIMITADA \\ Seção I \\ Constituição
}

Art. 980-A. Qualquer pessoa física que atenda ao disposto no art. 972, que exerça ou deseje exercer, profissionalmente, a atividade de empresário, poderá pode (sic) constituir Empreendimento Individual de Responsabilidade Limitada (ERLI).

$\S 1^{\circ}$ O patrimônio do Empreendimento Individual de Responsabilidade Limitada é próprio e distinto do de seu titular.

$\S 1^{o}$ (sic) Uma pessoa física só pode ser titular de um único Empreendimento Individual de Responsabilidade Limitada.

$\S 2^{\circ}$ O Empreendimento Individual de Responsabilidade Limitada regese, nas omissões deste Capítulo, subsidiariamente, pelas normas previstas para os empresários individuais e, no que couber, para as sociedades limitadas. 
Seção II

Da Inscrição

Art. 980-B. O Empreendimento Individual de Responsabilidade Limitada será constituído mediante registro no Registro Público de Empresas Mercantis de sua respectiva sede antes do início de sua atividade.

$\S 1^{\circ} \mathrm{A}$ inscrição de que trata o caput será feita mediante requerimento que contenha:

I - a qualificação pessoal da pessoa física titular do Empreendimento Individual de Responsabilidade Limitada, contendo seu nome, nacionalidade, domicílio, estado civil e regime de bens, se casado;

II - a firma, o capital, a sede e o objeto do empreendimento;

III - a declaração de que procedeu ao depósito das quantias indicadas a título de capital social, em dinheiro, ou dos bens corpóreos suscetíveis de avaliação pecuniária, com seu respectivo valor;

IV - o prazo de duração, podendo ser de prazo determinado ou indeterminado.

$\S 2^{\circ}$ O Empreendimento Individual de Responsabilidade Limitada opera sob firma, constituída pelo nome, completo ou abreviado, de seu titular, acrescido da expressão Estabelecimento Individual de Responsabilidade Limitada ou ERLI, podendo-se incluir descrição mais detalhada do ramo de atividade.

$\S 3^{\circ}$ Toda alteração do ato constitutivo deverá ser averbada no Registro Público de Empresas Mercantis à margem da inscrição do Empreendimento Individual de Responsabilidade Limitada.

\section{Seção III \\ Do Capital}

Art. 980-C. O capital será realizado em moeda corrente nacional ou bens suscetíveis de avaliação pecuniária. 
$\S 1^{\circ} \mathrm{O}$ capital deve estar integralmente liberado no momento em que for requerido o registro do Empreendimento Individual de

Responsabilidade Limitada e a parte em numerário deve encontrar-se depositada em instituição de crédito à ordem do titular do estabelecimento.

$\S 2^{\circ} \mathrm{O}$ depósito referido no $\S 1^{\circ}$ deve ser realizado em conta especial, que só poderá ser movimentada após o registro definitivo do Empreendimento Individual de Responsabilidade Limitada no Registro Público de Empresas Mercantis.

$\S 3^{\circ} \mathrm{O}$ depositante poderá levantar o depósito referido no $\S 1^{\circ}$ se o registro da constituição do Empreendimento Individual de Responsabilidade Limitada não for pedido no prazo de três meses a contar do depósito.

$\S 4^{o} \mathrm{Na}$ integralização de capital mediante bens, o pedido do registro deve ser instruído com a descrição pormenorizada de cada um deles, bem como de sua avaliação, por técnico especializado.

$\S 5^{\circ}$ Não se admite a constituição de Empreendimento Individual de Responsabilidade Limitada com capital a integralizar.

$\S 6^{\circ} \mathrm{Na}$ integralização do capital, o titular de Empreendimento Individual de Responsabilidade Limitada responde, pelo prazo de cinco anos a contar da integralização, com seu patrimônio pessoal e de forma ilimitada:

I - pelas incorreções na avaliação dos bens transmitidos a título de domínio, posse ou uso;

II - pela solvência dos créditos utilizados.

$\S 7^{\circ}$ Não se admite contribuição mediante prestação de serviços.

Seção IV

Da Administração

Art. 980-D. A administração de Empreendimento Individual de Responsabilidade Limitada caberá, exclusivamente, ao seu titular. 
$\S 1^{\circ}$ Em casos excepcionais, poderá o titular nomear mandatários especiais para a prática de atos determinados relativos ao objeto do Empreendimento Individual de Responsabilidade Limitada que não possa praticar.

$\S 2^{\circ}$ A nomeação de que trata o $\S 1^{o}$ far-se-á mediante instrumento público a ser averbado à margem da inscrição do Empreendimento Individual de Responsabilidade Limitada no Registro Público de Empresas Mercantis.

$$
\text { Seção } V
$$

Da Responsabilidade do Titular de Empreendimento Individual de

$$
\text { Responsabilidade Limitada }
$$

Art. 980-E. Pelas dívidas resultantes de atividades compreendidas no objeto do Empreendimento Individual de Responsabilidade Limitada respondem apenas os bens pertencentes ao empreendimento.

$\S 1^{\circ} O$ disposto no caput não afasta as normas relativas a responsabilidade previstas em leis especiais.

$\S 2^{\circ}$ O titular do Empreendimento Individual de Responsabilidade Limitada responderá com seu patrimônio pessoal na hipótese de aplicação de bens do Empreendimento Individual de Responsabilidade Limitada em benefício próprio ou de terceiro, devendo restituí-los ao empreendimento, com todos os lucros resultantes, ou pagar o equivalente em dinheiro, com todos os lucros resultantes e, se houver prejuízo, por eles também responderá.

\section{Seção VI}

Da Prestação de Contas

Art. 980-F. Ao término de cada exercício anual, o titular do Empreendimento Individual de Responsabilidade Limitada procederá à elaboração de balanço patrimonial e de resultado econômico, bem como à indicação do destino dos lucros e resultados obtidos para o próximo exercício. 
Seção VII

Da Remuneração pela Atividade

Art. 980-G. O titular do Empreendimento Individual de Responsabilidade Limitada poderá retirar remuneração mensal pela atividade exercida, tendo por referência o trabalho desempenhado.

Parágrafo único. A remuneração de que trata o caput não será paga em prejuízo do capital do empreendimento.

$$
\begin{gathered}
\text { Seção VIII } \\
\text { Da Dissolução e Liquidação }
\end{gathered}
$$

Art. 980-H. O Empreendimento Individual de Responsabilidade Limitada será extinto:

I- pela vontade de seu titular;

II - pelo término de seu prazo de duração;

III - pela incorporação ou fusão;

IV - pela cassação de autorização para funcionamento;

$V$-pela falência;

$V I$ - pela anulação do ato constitutivo;

VII - por morte de seu titular.

Parágrafo único. Na hipótese do inciso VII, os herdeiros poderão, no prazo de 180 (cento e oitenta) dias designar um novo titular escolhido entre eles."

Trata-se, sem sombra de dúvida, do mais completo projeto já apresentado ao Congresso brasileiro relativamente à limitação de responsabilidade do empresário individual.

Contudo, merece ser revisto em alguns aspectos, como a extinção em caso de morte do titular e a previsão de regramento subsidiário das normas aplicáveis aos empresários individuais. 
Demais disso, prevê a criação de um novo tipo de pessoa jurídica para exercício da atividade singular, mediante emenda ao artigo 44 do Código Civil, o que impossibilitaria a entrada, a qualquer tempo, de novos sócios, por inviável a transformação em sociedade. A nosso ver, essa limitação é absolutamente prejudicial e precisaria ser revista, para que seja o empreendimento individual uma das formas de organização da sociedade, e não nova pessoa jurídica.

Em parecer apresentado pelo Deputado Guilherme Campos (DEM-SP), relator da Comissão de Desenvolvimento Econômico, Indústria e Comércio, optou-se pela aprovação dos projetos de lei, mantida, contudo, a redação apresentada pelo Deputado Marcos Montes, porém com a nomenclatura Empreendimento Individual de Responsabilidade Limitada sugerida no projeto do Deputado Eduardo Sciarra.

O Deputado André Zacharow apresentou emenda ao substitutivo, sugerindo a previsão de que:

“(...) poderá ser atribuída à empresa individual de responsabilidade limitada, constituída para a prestação de serviços intelectuais de natureza científica, literária, jornalística, artística ou cultural, a remuneração decorrente da cessão de direitos patrimoniais de autor ou de imagem, nome, marca ou voz de que seja detentor o titular da pessoa jurídica, vinculados à atividade profissional."

A emenda foi integralmente aprovada pelo relator da Comissão de Desenvolvimento Econômico, Indústria e Comércio, com a inclusão, ainda, de atividades desportivas. Contudo, o Empreendimento Individual de Responsabilidade Limitada (ou empresa individual de responsabilidade limitada, como seja) é aplicável às atividades de caráter empresário, não abrangendo aquelas de cunho intelectual (em que a responsabilidade, diga-se, é ilimitada). A emenda é, pois, impertinente.

Assim mesmo, em 05.08.2009, o parecer do relator foi aprovado por unanimidade pela Comissão de Desenvolvimento Econômico, Indústria e Comércio e encaminhado à Comissão de Constituição e Justiça e de Cidadania.

Em 26.08.2009, a Comissão de Trabalho, de Administração e Serviço Público apresentou requerimento ao Presidente da Câmara para que fosse revisto o despacho inicial aposto ao Projeto de Lei n. ${ }^{\circ} 4.605 / 09$ (que previa apreciação do projeto 
apenas Comissões de Desenvolvimento Econômico, Indústria e Comércio e Constituição e Justiça e de Cidadania), tendo em vista ser de matéria de competência da Comissão de Trabalho. O requerimento foi indeferido, por "tratar de matéria relativa à instituição de empresa individual de responsabilidade limitada, alterando a Lei 10.406, de 10 de janeiro de 2002, não sendo tal matéria afeta ao campo temático ou área de atividade da Comissão de Trabalho".

Pelo que se pode averiguar, há, ainda, um longo caminho a ser trilhado para que o Brasil possa adaptar-se à tendência mundial de adoção da sociedade unipessoal, mas já existe, ao menos, um movimento legislativo inicial nesse sentido. 


\section{ESTRUTURA ORGANIZATIVA DA SOCIEDADE UNIPESSOAL}

Verificada a viabilidade jurídica da sociedade unipessoal, por meio da teoria do contrato-organização, há que se verificar seu arcabouço organizativo, a fim de possibilitar a estruturação dos pequenos empresários e permitir seu desenvolvimento e os efeitos benéficos à economia daí derivados.

\subsection{Tipos societários adequados à micro e pequena empresa}

A sociedade unipessoal, na teoria do contrato-organização, adquire independência total com relação às mudanças existentes no grupo de sócios, o que a enquadraria no ramo das sociedades de capital, e não de pessoas. Por esse motivo, defendia-se que a sociedade unipessoal deveria tomar a forma de sociedade anônima, em razão da maior separação entre sócios e administração verificada nesse tipo societário ${ }^{201}$.

No entanto, observa-se que a maioria absoluta das pequenas empresas adota a forma de sociedade limitada, em razão de sua maior simplicidade e flexibilidade com relação às sociedades anônimas ${ }^{202}$.

Inclusive, na maioria dos ordenamentos que adotam a sociedade unipessoal, ela está restrita às sociedades limitadas ${ }^{203}$. Esta se tornou, então, o protótipo ideal da sociedade unipessoal.

\footnotetext{
${ }^{201}$ Vigia, até então, a distinção entre sociedades anônimas como sociedades de capital e sociedades limitadas como sociedades de pessoas. Ressalte-se que, hodiernamente, apenas as sociedades anônimas de capital aberto são consideradas tipo legal capitalístico por natureza, da mesma forma que as cooperativas são obrigatoriamente personalísticas. Os demais tipos societários são abertos e sua caracterização como sociedade de pessoas ou de capitais depende de cada caso concreto.

${ }^{202} \mathrm{Na}$ Exposição de Motivos do Anteprojeto de Lei de Sociedades de Responsabilidade Limitada lê-se:

“(...) III - para sistematizar a disciplina da matéria, o Anteprojeto alicerça-se em três postulados. O primeiro traduz um fato social, econômico e histórico indiscutível: a sociedade de responsabilidade limitada é a forma típica, quiçá a única atualmente, da empresa de pequeno e médio porte, constituída e explorada por poucos sócios, as mais das vezes com vínculos familiares ou afetivos, com absoluto predomínio de um ou de alguns deles, quer nas assembléias gerais, ostentando a qualidade de sócio controlador, quer na gestão dos negócios sociais, ao exercer as funções de administrador, o que levou os comercialistas a ela se referirem como sendo, muitas das vezes, uma sociedade intuitu personae, em que predomina a affectio societatis, ou uma sociedade de pessoas e capitais. (...)" (Grifamos)

203 A Décima Segunda Diretiva da CEE em matéria de direito das sociedades, já analisada, prevê, em seu artigo $6^{\circ}$, que a criação de uma sociedade com um único sócio aplica-se, em princípio, às sociedades de responsabilidade limitada, podendo, no entanto, ser estendida às sociedades anônimas nos Estados-membros que permitam a existência de companhias com um único sócio. Atualmente, além da kleine
} 
Contudo, é inegável que as sociedades anônimas oferecem maior flexibilidade no que tange à alteração de sócios e transmissão dos negócios. Por esse motivo, a Comissão Europeia, por meio da Comunicação Relativa à Transmissão de Pequenas e Médias Empresas no 98/C 93/02, recomendou a adoção, pelos países membros, de estruturas simplificadas de sociedades anônimas que permitam, inclusive, a existência de sócio único.

Este tipo de sociedade anônima simplificada foi introduzido na Alemanha em 1994, mediante modificação da lei que rege as sociedades anônimas (Aktiengesetz), para permitir às pequenas e médias empresas adotarem mais facilmente a forma de uma sociedade anônima simplificada (kleine Aktiengesellschaft).

Prevendo certo número de benefícios fiscais para a criação de uma empresa deste tipo e para o seu funcionamento, como a redução das formalidades da assembleia geral anual para as sociedades que não ultrapassem determinada dimensão; a isenção da obrigação de dispor de um conselho fiscal para as empresas que empreguem menos de 500 pessoas; e a possibilidade de excluir o direito de adquirir prioritariamente novas ações, buscou-se, com a kleine Aktiengesellschaft, flexibilizar a estrutura da sociedade anônima para permitir sua utilização também pelos pequenos empresários, como alternativa às sociedades limitadas.

Na França, foi criada, em 1994, a Société par Actions Simplifiée, mas essa forma societária tem por objetivo facilitar a cooperação entre grandes empresas. Atualmente, encontra-se em estudo naquele país proposta sobre a modernização do direito societário, que prevê a redução dos critérios que regem a criação de uma sociedade anônima.

Apesar das vantagens que podem ser obtidas com a criação de uma sociedade anônima simplificada, no ordenamento brasileiro vigente é a sociedade limitada o tipo societário ideal a ser adotado pelas sociedades unipessoais empresárias, até mesmo porque as companhias (assim como as sociedades em comandita por ações) não podem se

Aktiengesellschaft alemã, Áustria, Dinamarca, Finlândia, Espanha, Países Baixos e Suécia admitem a sociedade anônima unipessoal. Na Bélgica, admite-se na sociedade anônima a unipessoalidade superveniente, mas não no momento da constituição. 
beneficiar das vantagens concedidas pelo Estatuto Nacional da Microempresa e da Empresa de Pequeno Porte ${ }^{204}$.

\subsection{A caracterização da unipessoalidade}

O critério mais direto para caracterização da unipessoalidade é o numérico, ou seja, a existência de um único sócio nos registros da empresa. É esse o critério adotado pela legislação brasileira, tanto para fins de reconhecimento da subsidiária integral ${ }^{205}$ como da unipessoalidade superveniente ${ }^{206}$.

É possível, no entanto, comprovar-se a unipessoalidade de fato, mediante indicação de critérios objetivos ${ }^{207}$ que demonstrem a intenção do sócio majoritário e dos

${ }^{204}$ Lei Complementar $n^{\circ}$ 123/06, Art. $3^{\circ}$ : "Para os efeitos desta Lei Complementar, consideram-se microempresas ou empresas de pequeno porte a sociedade empresária, a sociedade simples e o empresário a que se refere o art. 966 da Lei no 10.406, de 10 de janeiro de 2002, devidamente registrados no Registro de Empresas Mercantis ou no Registro Civil de Pessoas Jurídicas, conforme o caso, desde que:

(...)

$\S 4^{\circ}$ Não poderá se beneficiar do tratamento jurídico diferenciado previsto nesta Lei Complementar, incluído o regime de que trata o art. 12 desta Lei Complementar, para nenhum efeito legal, a pessoa jurídica:

(...)

$X$ - constituída sob a forma de sociedade por ações." (Grifamos)

${ }^{205}$ LSA, Art. 251: "A companhia pode ser constituída, mediante escritura pública, tendo como único acionista sociedade brasileira."

${ }^{206}$ Código Civil, Art. 1.033: "Dissolve-se a sociedade quando ocorrer:

(...)

IV - a falta de pluralidade de sócios, não reconstituída no prazo de cento e oitenta dias;

$(\ldots)$ ")

${ }^{207}$ Calixto Salomão Filho nos lembra, ainda, da aplicação do critério subjetivo (ou dos centros de atividade), pelo qual a unipessoalidade se verifica quando não existe qualquer minoria capaz de se contrapor ao poder de controle do controlador, ou seja, quando não haja outros centros de atividade que possam atuar paralelamente ao sócio majoritário.

Segundo o citado autor, essa teoria tem origem na Alemanha e foi desenvolvida visando delimitar a possibilidade de aplicar à venda de quotas da sociedade as regras relativas à venda da empresa.

Inicialmente, permitia-se a aplicação da disciplina da alienação de empresas quando se tratasse de venda da totalidade das quotas, pois teriam o mesmo resultado, em termos econômicos. Posteriormente, a aplicação da disciplina da alienação de empresas passou a ser admitida pela jurisprudência no caso de venda de quotas em montante suficiente para permitir a mudança do estatuto social (i.e. $75 \%$ das quotas).

A partir de então, teve início uma acirrada discussão a respeito dos limites da identificação sócio/empresa. Parte da doutrina era favorável à citada posição jurisprudencial. Outra parte entendeu que a titularidade da empresa pertence àquele que tem o poder de determinar sua sorte e a transferência de tais quotas seria equivalente à alienação da empresa. A maioria da doutrina, porém, entendeu que para a aquisição da 
sócios de favor de burlar a regra que prevê limitação de responsabilidade apenas para sociedades com dois ou mais sócios ${ }^{208}$.

A análise, contudo, deve ser criteriosa, pois há o risco de presumir-se de forma equivocada que sejam os minoritários sócios "de favor" do majoritário e, com isso, a possibilidade de que seus interesses sejam desconsiderados.

\subsection{Normas organizativas e de proteção a terceiros}

$\mathrm{Na}$ ausência de uma pluralidade de sócios, e, portanto, em razão da maior facilidade de confusão entre interesses sociais e pessoais do sócio único, é de suma importância a existência de uma série de rígidas regras organizativas e de proteção a

empresa significar pleno controle econômico da sociedade, não poderia existir qualquer minoria institucionalmente reconhecida capaz de contrapor-se ao poder de quem a controla, ou seja, uma minoria com número de votos necessário para convocar assembleias.

Cf. SALOMÃO FILHO, Calixto. A sociedade unipessoal. São Paulo: Malheiros, 1995. pp. 79-80.

208 Nesse sentido:

“APELAÇÃO CÍVEL - DECLARATÓRIA - DESCONSTITUIÇÃO DE SOCIEDADE JURÍDICA SIMULAÇÃO - Suposta sócia com 0,016\% do capital social. - Ausência de participação nos lucros. Percepção de salário fixo. - Sentença de procedência do pedido. - Anulação do negócio jurídico. Honorários advocatícios fixados em R\$4.000,00. - Incompetência da justiça estadual. - Inocorrência. Feito que visou desconstituição de personalidade jurídica, com anulação de contrato. - Ausência de ingresso na seara trabalhista, embora reconhecido o vínculo. - Simulação claramente verificada. - Sócio majoritário, estrangeiro, sem qualificação técnico-profissional. - Honorários advocatícios fixados abaixo do previsto na lei processual. - Adequação ao previsto no $\S 4^{\circ}$ do art. 20, do CPC. - Majoração para $R \$ 10.000,00$ (dez mil reais). - Reforma parcial da sentença. - REJEIÇÃO DA PRELIMINAR, IMPROVIMENTO DO RECURSO DOS RÉUS E PROVIMENTO PARCIAL DO RECURSO DA AUTORA.

(...)

Quanto ao mérito da demanda, convém ressaltar que no negócio jurídico realizado pelas partes e, ora impugnado, verificou-se ocorrência de simulação, na forma do artigo 167, § $1^{o}$, I do Código Civil de 2002, na medida em que simula conferir direitos aos adquirentes das cotas societárias, quando, em realidade, os confere aos alienantes, uma vez que os mantém com a gestão ilimitada da sociedade, assim demonstrado pelo mínimo percentual societário conferido à Autora, que ao que tudo demonstra, e como bem salientou a $d$. sentença: 'elementos cognoscíveis dos autos apontam no sentido de a autora ter servido apenas para poder investir e permanecer no país, sem, contudo, possuir realmente vontade de com ela desenvolver o fim comum e partilhar lucros'.

Tratando-se, como se trata, de negócio jurídico simulado, o mesmo é nulo, insuscetível, pois, na forma do artigo 169 da Lei Civil de confirmação ou convalidação, podendo, portanto, ser objeto de anulação a qualquer tempo.

Muito embora aleguem os ora Apelantes que a Autora dispunha, inclusive, de procuração ampla para gerir o negócio, esta se verificou prática diante da impossibilidade técnica do sócio majoritário, que sempre acompanhou, de bem perto, as atividades desempenhadas por sua 'sócia-minoritária'.

Desta forma, não merece reparos a r. sentença apelada, que bem analisou as provas e evidências dos autos, concluindo pela anulação do negócio jurídico de constituição da sociedade”. (TJRJ, AC 43602/08, Rel. Des. Sidney Hartung Buarque, $4^{\mathrm{a}}$ Câmara Cível, d.j. 14.10.2008) (Grifamos) 
terceiros, visando não só a clareza na separação entre os patrimônios, que permite a limitação de responsabilidade, mas também o amplo conhecimento de terceiros com relação à existência e manutenção dessa separação.

\subsubsection{Constituição e normas aplicáveis}

A criação da sociedade unipessoal deve observar os mesmos critérios de constituição das sociedades com mais de um sócio, tanto no que diz respeito à necessidade de registro no órgão próprio (o que exige forma escrita) quanto com relação à capacidade do sócio e licitude do objeto. No caso de unipessoalidade superveniente, é necessário adaptar os atos societários à nova situação e promover o registro regularmente.

No mais, a sociedade unipessoal deve seguir basicamente as mesmas regras aplicáveis ao tipo societário adotado, com as adaptações cabíveis.

\subsubsection{Publicidade das informações}

A assimetria de informações é um dos maiores dilemas econômicos, como magistralmente ilustrado por George A. Akerlof no clássico texto The Market for "Lemons": Quality Uncertainty and the Market Mechanism ${ }^{209}$. A informação assimétrica eleva os custos de transação, onerando o mercado e diminuindo a confiança e confiabilidade dos agentes.

Segundo Ronaldo Coase ${ }^{210}$, um dos papéis relevantes da organização da empresa é, justamente, a redução dos custos de transação. Quanto mais claras as regras, mais eficiente a produção e maior a quantidade e confiabilidade da informação, menores os custos do negócio. A organização empresarial objetiva tais fins, prevendo regras claras para seu funcionamento e atuação, maior eficiência produtiva pela aglutinação de bens e esforços e a ampla divulgação de informações, em razão da publicidade de seus atos.

209 AKERLOF, George A. "The market for 'lemons': quality uncertainty and the market mechanism". In: The Quarterly Journal of Economics, v. 84, issue 3, 1970. pp. 488-500.

${ }^{210}$ COASE, Ronald Harry. "The nature of the firm”. In: Economica, New Series, Vol. 4, No. 16, 1937. 
Um exemplo prático é a questão do patrimônio. Ao negociar com um empresário singular é muito difícil - ou, pode-se dizer, até mesmo impossível - para o agente ter real noção do patrimônio que irá garantir as obrigações do empresário, além de concorrer não só com os credores decorrentes da atividade empresária, mas também com os credores pessoais daquele.

Ao negociar com uma sociedade personalizada, o mesmo agente pode averiguar com relativa confiabilidade seu patrimônio (ou pelo menos o capital social), além de ter certeza de que tais bens somente estão sujeitos à concorrência de outros credores sociais. Reduz-se, assim, o custo de obtenção de informações pelo agente e, consequentemente, os custos de transação.

$\mathrm{Na}$ sociedade unipessoal, a importância da disponibilização ampla a terceiros das informações sociais é ainda maior, uma vez que, assim como nas sociedades pluripessoais em que os minoritários têm participação ínfima, existe uma maior facilidade de confusão entre o patrimônio social e os bens dos sócios. Faz-se, portanto, necessária a existência de regras claras que permitam a transparência das informações e o acesso de terceiros a estas.

A mera obrigatoriedade do registro, tanto na hipótese de unipessoalidade originária como superveniente, não é suficiente na prática comercial, que exige rapidez e eficiência nas transações, não sendo hábito dos empresários a verificação dos registros, até mesmo em função dos custos gerados. Desse modo, em especial os credores mais frágeis ficam impossibilitados de conhecer a real situação de seus devedores.

Deve-se, pois, dar-se preferência aos meios mais econômicos - e mais eficientes - de publicidade, como a agregação, no nome social, da expressão "sociedade unipessoal", a exemplo do que acontece com as microempresas ou empresas de pequeno porte. Trata-se de uma maneira eficaz de informar terceiros quanto à situação específica da empresa, e deve ser utilizada em todos os documentos e negócios da sociedade.

Necessário, demais disso, prever a obrigatoriedade de informar os credores em geral sobre eventual mudança decorrente de alteração da estrutura social, como, por exemplo, de empresário individual para sociedade unipessoal, ou a redução à unipessoalidade da sociedade pluripessoal. 
Ademais, mesmo que a organização interna da sociedade seja simplificada pela existência de um só sócio, é preciso que os procedimentos regulares da sociedade como a formalização por escrito e registro das deliberações sobre determinadas matérias e a obrigatoriedade de apresentação de contas dos administradores e balanços patrimoniais periódicos - sejam estritamente cumpridos, não só pela possibilidade de averiguação por terceiros, se necessário, mas também para proteção do próprio sócio em caso de arguição de confusão patrimonial ou existência de fraude.

\subsubsection{Garantias do capital social}

O capital social é, em última instância, a garantia dos credores e, portanto, são necessárias regras que o protejam e o tornem uma garantia efetiva

A proteção do capital já é regulada em razão do tipo societário adotado pela empresa - no caso das limitadas, por exemplo, os sócios são solidariamente responsáveis pela integralização do capital. Todavia, dadas as peculiaridades da sociedade unipessoal, são necessárias garantias adicionais.

$\mathrm{Na}$ maior parte dos ordenamentos em que são admitidas as sociedades unipessoais, exige-se que o capital social da empresa seja totalmente integralizado $a b$ initio, ou que sejam prestadas garantias firmes de sua integralização. No caso de sociedade reduzida à unipessoalidade em que o capital não esteja ainda totalmente integralizado, é necessário prever também a obrigatoriedade de pagamento imediato do remanescente pelo sócio único, ou a venda de parte das quotas, restaurando-se a pluripessoalidade.

Também é importante que ao menos uma parcela do capital social seja integralizada em numerário, devendo os bens eventualmente utilizados para realização do que sobejar serem avaliados por perito independente, ficando o sócio responsável pela correta avaliação e pela solvência dos créditos, se for o caso. Deve, ainda, ser vedada a contribuição em serviços.

Outra preocupação frequente - não restrita às sociedades unipessoais - é a subcapitalização. 
Como, no Brasil, não existem regras sobre capital mínimo ${ }^{211}$ e dificilmente existe uma verificação do valor do capital pelos credores, o mais comum é que as empresas tenham um capital social simbólico. Muitas vezes, inclusive, em havendo necessidade de capital adicional, os sócios, em lugar de elevar o capital social, celebram com a sociedade contratos de mútuo ${ }^{212}$.

Nesse sentido, entendemos que seria bastante benéfica a instituição no Brasil, à similaridade de diversos outros países, de valores mínimos de capital para constituição de sociedades, além de métodos efetivos para coibir o capital disfarçado de mútuo $^{213}$.

211 À exceção de empresas que exercem algumas atividades específicas e sujeitas a autorização para funcionamento, como intermediação financeira, seguradoras, capitalização e entidades abertas de previdência privada.

${ }^{212}$ Este assunto foi, inclusive, objeto do primeiro caso em que foi abordada a desconsideração da personalidade jurídica, no julgamento de Salomon v. A. Salomon and Co. (Limited), analisado em última instância pela House of Lords inglesa em 1896.

Segundo jurisprudência do Bundesgerichtshof (alto tribunal alemão), com base em decisões do Bundesfinanzhof (corte superior em matéria tributária e financeira), o empréstimo de sócio deve ser considerado como forma disfarçada de aumento de capital sempre que o acréscimo de novos meios financeiros seja, no caso concreto, objetivamente necessário e que a contribuição de sócio fosse o único meio possível de obtenção de tais recursos, já que a obtenção de crédito em fontes estranhas à sociedade não seria possível, nas circunstâncias do caso. Cf. OLIVEIRA, José Lamartine Corrêa de. A dupla crise da pessoa jurídica. São Paulo: Saraiva, 1979. p. 293.

Com base em tais entendimentos, a GmbH Novelle, de 1980, introduziu, como modificação na legislação societária a respeito da garantia do capital social (§ 32), a hipótese de que, em caso de falência ou recuperação da sociedade, eventuais empréstimos feitos pelo sócio à sociedade em uma situação em que terceiros se recusariam a fornecer-lhe crédito têm a natureza de mútuo desconsiderada e são entendidos como capital. Cf. SALOMÃO FILHO, Calixto. A sociedade unipessoal. São Paulo: Malheiros, 1995. pp. 164-165.

${ }^{213}$ Ressalte-se que a Medida Provisória $n^{\circ}$ 472, de 15.12.2009, trouxe algumas inovações relativamente ao tratamento dos empréstimos a pessoas vinculadas, mas com efeitos meramente tributários:

“Art. 24. Sem prejuízo do disposto no art. 22 da Lei 9430, de 1996, os juros pagos ou creditados por fonte situada no Brasil à pessoa física ou jurídica vinculada, nos termos do art. 23 da Lei 9430, de 1996, residente ou domiciliada no exterior, não constituída em país ou dependência com tributação favorecida ou sob regime fiscal privilegiado, somente serão dedutíveis, para fins de determinação do lucro real e da base de cálculo da contribuição social sobre o lucro líquido, quando se verifique constituírem despesa necessária à atividade, conforme definida pelo art. 47 da Lei 4506, de 30 de novembro de 1964, no período de apuração, atendendo cumulativamente aos seguintes requisitos:

I - o valor do endividamento, verificado na data da apropriação dos juros, não seja superior a duas vezes o valor da participação da vinculada no patrimônio líquido da pessoa jurídica residente no Brasil; $\boldsymbol{e}$

II - o valor total do somatório dos endividamentos, verificados na data da apropriação dos juros, não seja superior a duas vezes o valor do somatório das participaçães de todas as vinculadas no patrimônio líquido da pessoa jurídica residente no Brasil.

$\S 1^{\circ}$ Para efeito do cálculo do total de endividamento a que se refere o caput, deverão ser consideradas todas as formas e prazos de financiamento, independentemente de registro do contrato no Banco Central do Brasil. 


\subsubsection{Negócios entre sócio e sociedade}

Uma das questões polêmicas quando se trata das sociedades unipessoais é a possibilidade de negócios entre o sócio e a sociedade ${ }^{214}$.

A nosso ver, não deve ser vedada a possibilidade de negociação entre sócio único e sociedade. Isso porque a menos que a intenção seja efetivamente lesar os credores

$\$ 2^{\circ}$ Aplica-se o disposto neste artigo às operações de endividamento de pessoa jurídica residente ou domiciliada no Brasil, em que o avalista, fiador, procurador ou qualquer interveniente for pessoa vinculada.

$\$ 3^{\circ}$ Verificando-se excesso em relação aos limites fixados nos incisos I e II do caput deste artigo, o valor dos juros relativos ao excedente será considerado despesa não necessária à atividade da empresa, conforme definida pelo art. 47 da Lei 4506, de 1964, e indedutível para fins de Imposto de Renda e da Contribuição Social sobre o Lucro Líquido.

Art. 25. Sem prejuízo do disposto no art. 22 da Lei 9430, de 1996, os juros pagos ou creditados por fonte situada no Brasil à pessoa física ou jurídica residente, domiciliada ou constituída no exterior, em país ou dependência com tributação favorecida ou sob regime fiscal privilegiado, nos termos dos arts. 24 e 24-A da Lei 9430, de 1996, somente serão dedutíveis, para fins de determinação do lucro real e da base de cálculo da contribuição social sobre o lucro líquido, quando se verifique constituírem despesa necessária à atividade, conforme definida pelo art. 47 da Lei 4506, de 1964, no período de apuração, atendendo cumulativamente aos seguintes requisitos:

I - o valor do endividamento com a entidade situada em país ou dependência com tributação favorecida ou sob regime fiscal privilegiado não seja superior a trinta por cento do valor do patrimônio líquido da pessoa jurídica residente no Brasil;

II - o valor total do somatório dos endividamentos com todas as entidades situadas em país ou dependência com tributação favorecida ou sob regime fiscal privilegiado não seja superior a trinta por cento do valor do patrimônio líquido da pessoa jurídica residente no Brasil.

$\$ 1^{\circ}$ Para efeito do cálculo do total do endividamento a que se refere o caput, deverão ser consideradas todas as formas e prazos de financiamento, independentemente de registro do contrato no Banco Central do Brasil.

$\$ 2^{\circ}$ Aplica-se o disposto neste artigo às operações de endividamento de pessoa jurídica residente ou domiciliada no Brasil, em que o avalista, fiador, procurador ou qualquer interveniente for residente ou constituído em país ou dependência com tributação favorecida ou sob regime fiscal privilegiado.

$\$ 3^{\circ}$ Verificando-se excesso em relação aos limites fixados nos incisos I e II do caput deste artigo, o valor dos juros relativos ao excedente será considerado despesa não necessária à atividade da empresa, conforme definida pelo art. 47 da Lei 4506, de 1964, e indedutível para fins de Imposto de Renda e da Contribuição Social sobre o Lucro Líquido." (Grifos nossos)

${ }^{214}$ Na Alemanha, antes da promulgação da GmbH Novelle, em 1980, tal prática era amplamente admitida. Atualmente, por conta da proibição dos contratos consigo mesmo introduzida por aquela peça legislativa, passou a ser vedada, inclusive nas sociedades unipessoais.

A jurisprudência amenizou a proibição legal, decidindo pela possibilidade dos negócios entre sócio e sociedade caso haja previsão expressa no contrato social, pois, desse modo, seria, em teoria, conhecida dos credores em razão do registro.

Como se sabe, contudo, em raríssimas hipóteses o credor, em negócios do dia-a-dia, verifica o teor dos contratos sociais daqueles com quem negocia, de modo que seria muito mais efetiva a obrigatoriedade de publicidade do próprio negócio consigo mesmo do que a mera necessidade de previsão contratual da mesma.

Cf. SALOMÃO FILHO, Calixto. A sociedade unipessoal. São Paulo: Malheiros, 1995. pp. 167-168. 
sociais, o sócio único não tem incentivos para prejudicar o bom andamento de sociedade que apenas a ele pertence; diferentemente de quando há outros sócios, em que o prejuízo à sociedade poderia, eventualmente, trazer ganhos ao sócio envolvido na negociação.

Contudo, tais atos devem ser celebrados em consonância com a praxe de mercado e a eles deve, sempre, ser dada a devida publicidade, além de tomarem necessariamente a forma escrita, como forma de garantia de regularidade não só com relação a terceiros, mas também pelo próprio sócio único que pode, em eventual contestação, comprovar documentalmente a regularidade do ato.

Se observadas as regras de publicidade e organização empresarial, além das garantias a terceiros, não se vê, na adoção da sociedade unipessoal, qualquer possibilidade de fraude ou confusão patrimonial maior do que a que se observa em qualquer outra estrutura societária. E, em se comprovando a existência de irregularidades, o sócio único, assim como os sócios das sociedades tradicionais, poderá ser responsabilizado de forma pessoal e ilimitada pelos danos causados. 


\section{CONCLUSÃO}

A responsabilização patrimonial ilimitada dos devedores teve início no século IV a.C., quando se deixou de exigir que o devedor respondesse com a própria vida ou com a liberdade. A partir de então, o crescente desenvolvimento das atividades econômicas foi, gradativamente, tornando a sociedade mais complexa.

O indivíduo, por si só incapaz de realizar certos fins que ultrapassam suas forças e os limites da vida humana, viu-se impelido a unir-se a outros homens, formando associações. Paralelamente a essa premência da união de pessoas e recursos para possibilitar empresas de maior vulto surgiu a necessidade de preservação dos bens pessoais dos envolvidos em tais projetos.

Essa situação deu azo ao desenvolvimento do instituto da pessoa jurídica, transformando as coletividades em centros autônomos de imputação de direitos e obrigações com capacidade para o exercício de atos jurídicos previstos no direto positivo, acarretando, inclusive, a possibilidade de autonomia patrimonial, ou seja, a distinção entre o patrimônio da pessoa jurídica e dos membros que a compõem ou dirigem.

E a personalização, por sua vez, permitiu a evolução e ampliação das atividades empresariais, especialmente quando também se desenvolveram os sistemas de limitação de responsabilidade dos sócios.

A limitação da responsabilidade ao patrimônio do ente coletivo de forma autônoma e destacada do patrimônio de seus integrantes, adotada em determinados tipos sociais, foi amplamente aceita nos diversos ordenamentos jurídicos. A questão da limitação da responsabilidade do empresário individual, todavia, foi objeto de acirrada polêmica.

O individualismo reinante durante a maior parte dos séculos XIX e XX e a forte concepção de unidade e indivisibilidade do patrimônio dificultavam a aceitação da separação patrimonial da pessoa singular. Demais disso, a concepção de sociedade como vontade da pessoa coletiva conformada pela pluralidade de seus componentes levava à rejeição da limitação da responsabilidade do empresário individual. 
Para contornar a restrição, muitos empresários optaram pela criação de sociedades "fictícias", ou "de favor", valendo-se do auxílio e concordância de terceiros para aproveitar-se dos benefícios da responsabilidade limitada no exercício de suas atividades. Tal expediente, contudo, mesmo que possa ser considerado juridicamente válido, não é desejável, seja em razão dos inúmeros problemas que o relacionamento entre sócios - mesmo que de favor - pode acarretar, seja em razão dos efeitos deletérios trazidos aos que participam da ficção.

Última fase de evolução da noção jurídica de responsabilidade, observou-se, nas últimas décadas, um movimento amplo e global no sentido da adoção da limitação de responsabilidade do empresário individual. Isso porque se a lei reconhece a existência de um interesse social na limitação do risco dos empreendimentos coletivos, esse mesmo interesse manifesta-se relativamente aos empresários individuais.

Em função de tal reconhecimento, a limitação de responsabilidade do empresário singular tem se tornado cada vez mais comum nos diversos ordenamentos jurídicos, seja por meio do reconhecimento da limitação em formas não societárias, seja de forma amplamente majoritária - pela adoção das sociedades unipessoais.

A limitação de responsabilidade pela via do patrimônio de afetação encontrou barreiras na teoria subjetiva do patrimônio, prevalente até meados do século XX, que apregoava ser o patrimônio emanação da personalidade, de modo que, assim como a personalidade, seria uno e indivisível. A unicidade patrimonial teria como finalidade precípua amparar os credores do detentor do patrimônio com a integralidade deste, independentemente da época de aquisição dos bens ou direitos.

O conceito da unicidade patrimonial foi sendo paulatinamente relativizado, sendo, hoje, aceita de forma praticamente inconteste a divisibilidade do patrimônio e a coexistência do patrimônio geral (os direitos, pretensões, ações e exceções patrimoniais da pessoa, que atendem a fins gerais) e de patrimônios especiais, destinados a um fim específico.

O patrimônio afetado permite ao empresário limitar o risco do negócio, de modo que dívidas decorrentes da atividade comercial não atinjam seu patrimônio pessoal. Da mesma forma, assegura aos credores por dívidas derivadas da atividade praticada com o 
patrimônio afetado que os credores particulares do empresário não terão acesso àqueles bens, garantindo, por sua vez, os credores pessoais do empresário seu patrimônio geral.

Em razão da afetação patrimonial, o patrimônio especial estará sujeito a disciplina jurídica diversa daquela a que é submetido o patrimônio pessoal do empresário, sem que haja, todavia, surgimento de um novo ente jurídico.

A limitação de responsabilidade por via da separação patrimonial foi implantada em Portugal, em 1986. Arraigados à escola contratualista e, portanto, avessos à concepção institucional da sociedade unipessoal, foi criado o Estabelecimento Individual de Responsabilidade Limitada (EIRL). Dez anos mais tarde, contudo, o legislador português reconheceu que a criação do EIRL não atingiu os resultados esperados de facilitação da criação e desenvolvimento de pequenas empresas.

$\mathrm{Na}$ França houve também algumas tentativas de adoção da técnica de afetação patrimonial para empresários singulares, mas os projetos previam formalidades excessivas e a ideia acabou descartada.

No Brasil, a limitação da responsabilidade do empresário individual pela adoção do patrimônio de afetação foi amplamente defendida por Sylvio Marcondes. Partindo dos conceitos germânicos de Schuld e Haftung, defende aquele autor que o sentido habitualmente concedido à "responsabilidade limitada", qual seja, a determinação de certa importância pela qual responde o devedor, é impreciso, pois a limitação seria, propriamente, da dívida, e não da responsabilidade. O devedor responderia, pois, de forma ilimitada, com todos os seus bens, mas por uma dívida limitada.

A limitação de responsabilidade, a rigor, dar-se ia apenas quando se demarcasse uma área circunscrita de bens destinada a suportar os direitos dos credores dita responsabilidade objetivamente limitada - já que a responsabilidade pela dívida estaria delimitada ao valor dos objetos sobre o qual tal responsabilidade recai, não podendo o credor exigir senão aqueles em caso de insatisfação da dívida. Desse modo, a verdadeira limitação de responsabilidade somente poderia ser alcançada pela separação patrimonial, circunscritos os bens responsáveis. 
Segundo a tese de Marcondes, o patrimônio separado centralizaria as relações jurídicas emergentes da atividade do comerciante singular, imprimindo cunho jurídico ao conceito econômico de empresa. A empresa individual com responsabilidade limitada seria, pois, objeto de direito pertencente ao empresário, mantendo-se com este a qualidade de sujeito de direito e titular das obrigações decorrentes.

Tal expediente traz, contudo, uma série de inconvenientes, como a dificuldade de transmissão da empresa a terceiros, a impossibilidade de ampliação do negócio e de obtenção de crédito descolado da figura do empresário e a dificuldade em manter a separação patrimonial e a necessária distinção entre o empresário e a pessoa jurídica empresária.

Relativamente à transmissão do estabelecimento, é vedada a transferência a terceiros sem consentimento dos credores respectivos e sem que o empresário tenha bens suficientes para resolver o passivo, sob pena de ineficácia do trespasse. Demais disso, a extinção em razão da morte do empresário acarretaria a liquidação da empresa no juízo do inventário.

A insolvência da empresa singular leva, necessariamente, à falência do empresário, como sujeito de direito e titular das execuções dos credores, vez que a empresa individual não ostenta personalidade jurídica separada e independente da de seu titular.

No que diz respeito à ampliação do negócio, fica também prejudicada por não ser possível agregar novos sócios ou mesmo incluir ou excluir bens do patrimônio especial, sob pena de violação das garantias ora dos credores particulares do empresário, ora dos credores empresariais. Ainda mais, a limitação de responsabilidade que pode ser obtida pela afetação patrimonial não permite ao empresário individual ter acesso a crédito descolado de sua pessoa.

Finalmente, ressalta-se a dificuldade em manter, perante terceiros, a necessária distinção entre o empresário e o estabelecimento, pois que, inexistindo a personalidade jurídica, senão meramente uma separação patrimonial, maior a possibilidade de confusão por terceiros, dada a tênue distinção entre empresário e empresa. 
A sociedade unipessoal, por outro lado - embasada pela hoje amplamente aceita teria do contrato-organização e pela concepção institucional da sociedade, que as enxerga como uma estrutura organizativa que serve de instrumento à obtenção de determinados fins - possibilita a criação de uma pessoa jurídica separada da figura do empresário. Assim, não só garante a limitação de responsabilidade do empresário singular, mas também permite a ampliação na circulação e liquidez da empresa e possibilita sua independência e perpetuidade em relação ao sócio.

Possibilita, portanto, a preservação da empresa, conceito que se encontra incrustado no bojo do Código Civil de 2002

A adoção da sociedade unipessoal pelo ordenamento brasileiro depende de adaptações legislativas, em especial no que se refere ao conceito contratualista clássico de sociedade. É, contudo, perfeitamente possível e juridicamente justificável a existência de sociedade sem uma pluralidade de sócios, ademais dos benefícios econômicos advindos desse reconhecimento jurídico.

Por óbvio que a instituição da sociedade unipessoal depende de uma estrita regulação de suas relações internas e externas e da necessária proteção aos direitos e interesses de terceiros, visando não só a clareza na separação entre os patrimônios, que permite a limitação de responsabilidade, mas também o amplo conhecimento de terceiros com relação à existência e manutenção dessa separação.

É necessária, portanto, a disponibilização ampla a terceiros das informações sociais, por meio do registro dos atos societários; a obrigatoriedade de agregação, no nome social, da expressão "sociedade unipessoal" e seu uso em todos os documentos e negócios; e a necessidade de divulgação ampla a terceiros quando de eventual mudança relativamente ao caráter de unipessoalidade.

Demais disso, é preciso que os procedimentos regulares da sociedade como a formalização por escrito e registro da deliberação sobre determinadas matérias e a obrigatoriedade de apresentação de contas dos administradores e balanços patrimoniais periódicos - sejam estritamente cumpridos, não só pela possibilidade de averiguação por terceiros, se necessário, mas também para proteção do próprio sócio único. 
No mais, faz-se necessária a instituição de garantias quanto à integridade do capital social, como a obrigatoriedade de integralização ab initio ou compromisso firme de integralização; avaliação independente dos bens e responsabilização pessoal pela correta avaliação e solvência dos créditos; e, quiçá, a instituição de regras relativas ao capital mínimo para estabelecimento de empresa, hoje inexistentes no Brasil para a maior parte das atividades. Também é importante coibir a prática dos empréstimos travestidos, quando na verdade o que se busca e o reforço do capital social.

E, no que diz respeito a eventuais negócios entre sócio único e sociedade, entendemos que não devem ser vedados, mas devem observar sempre a praxe de mercado, além de receberem a devida publicidade e tomarem necessariamente a forma escrita.

Observadas as regras de publicidade e organização empresarial, além das garantias a terceiros, não se vê, na adoção da sociedade unipessoal, qualquer possibilidade de fraude ou confusão patrimonial maior do que a que se observa em qualquer outra estrutura societária.

As micro e pequenas empresas representam, do ponto de vista socioeconômico, relevante fenômeno, não só no Brasil mas em âmbito global e devem, pois, serem fortalecidas mediante o fornecimento de incentivos e ampliação de crédito e, principalmente, investimentos na desburocratização e facilitação da legalização dos pequenos empresários.

É fato que a maior parte dos pequenos empresários age por conta própria, ficando sujeitos, de acordo com a legislação brasileira, ao comprometimento da integralidade de seu patrimônio no exercício da empresa, como é o caso dos empresários individuais, ou à necessidade de submissão a uma sociedade muitas vezes indesejada para obtenção de algum tipo de limitação de responsabilidade.

Como visto no presente trabalho, a adoção, pelo ordenamento brasileiro, da sociedade unipessoal é não só possível, mas também benéfica para o fortalecimento dos pequenos negócios, tanto do ponto de vista da limitação da responsabilidade do empresário singular como da preservação da empresa, possibilitando sua independência, desenvolvimento e perpetuidade. Não é, por óbvio, o suficiente para, por si só, incentivar a criação de novos negócios ou a regularização dos já existentes, mas já é, sim, um bom começo e um passo importante nesse sentido. 


\section{REFERÊNCIAS BIBLIOGRÁFICAS}

AKERLOF, George A. “The market for 'lemons': quality uncertainty and the market mechanism”. In: The Quarterly Journal of Economics, v. 84, issue 3, 1970.

ASCARELLI, Tullio. “O empresário" (trad. de Fábio Konder Comparato). In: Revista de Direito Mercantil Industrial, Econômico e Financeiro, v. 109, 1998.

. "O desenvolvimento histórico do direito comercial e o significado da unificação do direito comparado" (trad. de Fábio Konder Comparato). In: Revista de Direito Mercantil Industrial, Econômico e Financeiro, v. 114, 1999.

. Problemas das sociedades anônimas e direito comparado.

Campinas: Bookseller, 2001.

ASQUINI, Alberto. "Profili dell'impresa". In: Rivista di diritto commerciale, vol. XLI, parte I, 1943.

BARRETO FILHO, Oscar. Teoria do estabelecimento comercial: fundo de comércio ou fazenda mercantil. São Paulo: Max Limonad, 1969.

BEVILÁQUA, Clóvis. Código civil dos Estados Unidos do Brasil-comentado. $4^{\mathrm{a}}$ ed. Rio de Janeiro: Francisco Alves, 1993. v. 1.

BORGES, João Eunápio. Curso de direito comercial terrestre. Rio de Janeiro: Forense, 1964.

BRUSCATO, Wilges Ariana. Empresário individual de responsabilidade limitada. São Paulo: Quartier Latin, 2005.

BULGARELLI, Waldírio. Sociedades comerciais. $8^{\text {a }}$ ed. São Paulo: Atlas, 1999.

CAMPINHO, Sérgio. O direito de empresa à luz do novo código civil. $10^{\mathrm{a}}$ ed. revista e atualizada de acordo com a lei complementar $n^{\circ}$ 128/2008. Rio de Janeiro: Renovar, 2009.

CANAVEZ, Luciana Lopes. "A sociedade em comum como modelo de sociedade empresária no Novo Código Civil". In: Revista Jurídica da Universidade de Franca, ano 6, n. $11,2003$. 
CARVALHO DE MENDONÇA, José Xavier. Tratado de direito comercial brasileiro. $4^{\mathrm{a}}$ ed. Rio de Janeiro: Freitas Bastos, 1945. t. III, v. III.

CATAPANI, Márcio Ferro. “Os contratos associativos”. In: FRANÇA, Erasmo Valladão Azevedo e Novaes (org.). Direito societário contemporâneo I. São Paulo: Quartier Latin, 2009.

CHULIA, Francisco Vicent. Introducción al derecho mercantil. Valencia: Tirant lo blanc, 1999.

COASE, Ronald Harry. "The nature of the firm". In: Economica, New Series, Vol. 4, No. 16, 1937.

COMPARATO, Fábio Konder. O poder de controle na sociedade anônima. São Paulo: RT, 1976.

COSTA, Carlos Celso Orcesi da. "Empresas unipessoais”. In: Revista de Direito Mercantil Industrial, Econômico e Financeiro, v. 51, 1983.

COSTA, Philomeno Joaquim da. “Comentário a acórdão”. In: Revista de Direito Mercantil Industrial, Econômico e Financeiro, v. 53, 1984.

COSTA, Ricardo Alberto Santos. Sociedade por quotas unipessoal no direito português. Coimbra: Almedina, 2002.

COZIAN, Maurice; VIANDIER, Alain; DEBOISSY, Florence. Droits des societès. $18^{\mathrm{a}}$ ed. Paris: Litec, 2005.

CRISTIANO, Romano. A empresa individual e a personalidade jurídica. São Paulo: RT, 1977. A subsidiária integral no Brasil. São Paulo: RT, 1986.

DAIGRE, Jean-Jacques. "La societé unipersonnelle". In: Revue internationale de droit compare, v. 42, n. 2. Société de Législation Comparée: Paris, 1990.

DINIZ, Gustavo Saad. Responsabilidade dos administradores por dívidas das sociedades limitadas. Porto Alegre: Síntese, 2003. 
FERRARA, Francesco. Teoria delle persone giuridiche. $2^{\mathrm{a}}$ ed. riveduta. Torino: UTET, 1923.

FERRAZ JR., Tércio Sampaio. Introdução ao estudo do direito: técnica, decisão, dominação. $2^{\text {a }}$ ed. São Paulo: Atlas, 1994.

FÉRES, Marcelo Andrade. "A depuração da sociedade em comum: primeiras considerações sobre o regime jurídico das sociedades contratuais em formação". In: Repertório de Jurisprudência IOB, n. 19, v. 3, 2004.

FERREIRA, Waldemar. Instituições de direito comercial. Rio de Janeiro: Freitas Bastos, 1944. v. 1.

Tratado de Direito Comercial. São Paulo: Saraiva, 1960.

FERRER CORREIA, António de Arruda. Sociedades fictícias e unipessoais. Coimbra: Atlântida, 1948.

FERRO-LUZZI, Paolo. I contratti associativi. Milano: Giuffré, 2001.

FRANCO, Vera Helena de Mello. "O triste fim das sociedades limitadas no novo Código Civil”. In: Revista de Direito Mercantil Industrial, Econômico e Financeiro, v. 123, 2001.

Direito empresarial. O empresário e seus auxiliares.

O estabelecimento empresarial. As sociedades. $3^{\mathrm{a}}$ ed. rev, atual. e ampl. São Paulo: RT, 2009. v. 1.

FRANCO, Vera Helena de Mello; SZTAJN, Rachel. Direito empresarial. Sociedade anônima. Mercado de valores mobiliários. $2^{\mathrm{a}}$ ed. rev, atual. e ampl. São Paulo: RT, 2009. v. 2 .

FRONTINI, Paulo Salvador. "Pessoas jurídicas no código civil de 2002 - elenco, remissão histórica e disposições gerais". In: Revista de Direito Mercantil Industrial, Econômico e Financeiro, v. 137, 2005.

GALGANO, Francesco. Diritto commerciale: le società. $15^{\mathrm{a}}$ ed. Bologna: Zanichelli, 2005.

GOMES, Orlando. Introdução ao direito civil. 10ª ed. Rio de Janeiro: Forense, 1991. 
GONÇALVES NETO, Alfredo de Assis. Direito de empresa: comentários aos artigos 966 a 1.195 do código civil. $2^{\mathrm{a}}$ ed. revista, atualizada e ampliada. São Paulo: RT, 2008.

HAURIOU, Maurice. "La théorie de l'institution et de la fondation: essay de vitalisme social". In: La cité moderne et les transformations du droit, Cahiers de la nouvelle journée n. 4. Paris: Bloud et Gay, 1925.

INSTITUTO BRASILEIRO DE GEOGRAFIA E ESTATÍSTICA. As micro e pequenas empresas comerciais e de serviços no Brasil 2001. Rio de Janeiro, 2003.

JAEGER, Pier Giusto. L’interesse sociale. Milano: Giuffré, 1964.

"L'interesse sociale rivisitato (quarant'anni dopo)". In: Giurisprudenza Commerciale, Milano: Giuffré, 2000.

JUSTEN FILHO, Marçal, Desconsideração da personalidade societária no direito brasileiro, São Paulo: RT, 1987.

KALANSKY, Daniel. “A sociedade em comum: um novo tipo societário?”. In: FRANÇA, Erasmo Valladão Azevedo e Novaes (org.). Direito societário contemporâneo I. São Paulo: Quartier Latin, 2009.

KELSEN, Hans. Teoria pura do direito. São Paulo: Martins Fontes, 1998.

LIMONGI FRANÇA, Rubens. Instituições de direito civil. $4^{\mathrm{a}}$ ed. atual. São Paulo: Saraiva, 1996.

LYNCH, Maria Antonieta. "O patrimônio de afetação e as empresas individuais de responsabilidade limitada". In: Revista de Direito Mercantil Industrial, Econômico e Financeiro, v. 148, 2007.

MAMEDE, Gladston [et. al.]. Comentários ao estatuto Nacional da Microempresa e da Empresa de Pequeno Porte: lei complementar $n^{\circ} 123$, de 14 de dezembro de 2006. São Paulo: Atlas, 2007.

MAMEDE, Gladston. Direito empresarial brasileiro: empresa e atuação empresarial. $3^{\text {a }}$ ed. São Paulo: Atlas, 2009. v. 1. 
MARCONDES MACHADO, Sylvio. Ensaio sobre a sociedade de responsabilidade limitada. São Paulo: RT, 1940.

- Limitação de responsabilidade de comerciante individual. São Paulo: Max Limonad, 1956.

. Problemas de direito mercantil. São Paulo: Max

Limonad, 1970.

. "Exposição de motivos complementar". In: Código

civil: anteprojetos. Senado Federal, 1973. v. 5, t. 2.

Questões de direito mercantil. São Paulo: Saraiva,

1977.

MARTINS, Fran. "Sociedade por quotas unipessoal". In: Novos estudos de direito societário. São Paulo: Saraiva, 1988.

Curso de direito comercial. Rio de Janeiro: Forense, 2000.

MELO, Cinira Gomes Lima. "A limitação de responsabilidade do empresário individual”. In: Revista de Direito Mercantil Industrial, Econômico e Financeiro, v. 137, 2005.

MONTEIRO, Washington de Barros. Curso de direito civil: parte geral. 42a ed. São Paulo: Saraiva, 2009.

MUNHOZ, Eduardo Secchi. Empresa contemporânea e o direito societário. São Paulo: Juarez de Oliveira, 2002.

NONES, Nelson. "A empresa individual de responsabilidade limitada e o anteprojeto de lei das sociedades de responsabilidade limitada". In: Novos estudos jurídicos, ano VI, $\mathrm{n}^{\circ} 13$, 2001.

OLIVEIRA, José Lamartine Corrêa de. A dupla crise da pessoa jurídica. São Paulo: Saraiva, 1979. 
PALERMO, Fernanda Kellner de Oliveira. "As micro e pequenas empresas como propulsoras do desenvolvimento econômico e social - contribuição para o incremento das atividades econômicas no âmbito do MERCOSUL". In: Revista de Direito Mercantil Industrial, Econômico e Financeiro, v. 124, 2001.

PEREIRA, Caio Mário da Silva. Instituições de direito civil. $12^{\mathrm{a}}$ ed. Rio de Janeiro: Forense, 1991. v. 1.

PEREIRA, Pedro Barbosa. Curso de direito comercial - sociedades comerciais e títulos de crédito. São Paulo: RT, 1969. v. 2.

PONTES DE MIRANDA, Francisco Cavalcanti. Tratado de direito privado. Rio de Janeiro: Borsoi, 1954. t. I, v. 1.

Tratado de direito privado. $3^{\mathrm{a}}$ ed. Rio

de Janeiro: Borsoi, 1970. t. V.

Tratado de direito privado. $3^{\mathrm{a}}$ ed. Rio

de Janeiro: Borsoi, 1972. t. XLIX.

PRADO FILHO, José Inácio Ferraz de Almeida. "Notas sobre as sociedades fictícias, ou de favor". In: Revista de Direito Mercantil Industrial, Econômico e Financeiro, v 134, 2004.

RÁO, Vicente. O direito e a vida dos direitos. $4^{\mathrm{a}}$ ed. São Paulo: RT, 1997. v. 2.

REALE, Miguel. Lições preliminares de direito. 16ª ed. São Paulo: Saraiva, 1988.

REQUIÃO, Rubens. Curso de direito comercial. $23^{\mathrm{a}}$ ed. São Paulo: Saraiva, 1998.

RODRIGUES, Silvio. Direito civil. 25ª ed. atual. São Paulo: Saraiva, 1995. v. 1.

SALOMÃO FILHO, Calixto. A sociedade unipessoal. São Paulo: Malheiros, 1995. . O novo direito societário. $2^{\mathrm{a}}$ ed. reformulada. São Paulo:

Malheiros, 2002.

. "Sociedade simulada". In: Revista de Direito Mercantil

Industrial, Econômico e Financeiro, v. 105, 1997. 
SERPA LOPES, Miguel Maria de. Curso de direito civil. $8^{\mathrm{a}}$ ed. Rio de Janeiro: Freitas Bastos, 1996. v. I.

SERVIÇO BRASILEIRO DE APOIO ÀS MICRO E PEQUENAS EMPRESAS. As empresas de menor porte na economia nacional: alguns indicadores selecionados. 1991. . Participação das MPEs no total de pessoas ocupadas nas empresas paulistas: 1995/1999 (Relatório de Pesquisa). São Paulo, 2000. . Coletânea estatística da micro e pequena empresa II. 2000.

. Guia básico sobre os pequenos negócios no Estado de São Paulo. BEDÊ, Marco Aurélio (org.). $2^{\text {a }}$ ed. rev. e ampl. São Paulo, 2006.

. Onde estão as micro e pequenas empresas no Brasil. BEDÊ, Marco Aurélio (coord.). São Paulo, 2006.

SOUZA JUNIOR, Francisco Satiro de; PITOMBO, Antônio Sergio A. de Moraes (coord.). Comentários à lei de recuperação de empresas e falência: Lei 11.101/2005. São Paulo: RT, 2006.

SOUZA, Thelma de Mesquita Garcia e. "Sociedade unipessoal como solução organizativa da empresa". In: FRANÇA, Erasmo Valladão Azevedo e Novaes (org.). Direito Societário Contemporâneo I. São Paulo: Quartier Latin, 2009.

SZTAJN, Rachel. Contrato de sociedade e formas societárias. São Paulo: Saraiva, 1989. . “Associações e sociedades". In: Revista de Direito Mercantil Industrial, Econômico e Financeiro, v. 128, 2002.

. “Terá a personificação das sociedades função econômica?”. In: Direito empresarial: aspectos atuais de direito empresarial brasileiro e comparado. São Paulo: Método, 2005.

TAVARES BORBA, José Edwaldo. Direito societário. $4^{\mathrm{a}}$ ed. Rio de Janeiro: Freitas Bastos, 1998.

VENOSA, Silvio de Salvo. Direito civil: parte geral. $6^{\text {a }}$ ed. São Paulo: Atlas, 2006. v. 1. 
VERÇOSA, Haroldo Malheiros Duclerc. Curso de direito comercial: teoria das sociedades, as sociedades em espécie do código civil. São Paulo: Malheiros, 2006. v. 2.

WORLD BANK. World Development Report 2005: A Better Investment Climate For Everyone, 2005. 